\title{
The Impact of Trade Liberalisation on Decent Work: The Case of the Philippine Sugar Mill Workers
}

\author{
By
}

Johana Sellado Jadoc

\begin{abstract}
A thesis submitted to Victoria University of Wellington in fulfilment of the requirements for the degree of

Master of Commerce in Administration in Human Resource and Industrial Relations
\end{abstract}

Victoria University of Wellington

2013 


\section{Abstract}

The impact of trade liberalisation on the structure and nature of work is a divisive topic. On the one hand, there are those who support trade liberalisation by pointing to the potential employment generation (Kelly \& Prokhovnik, 2004) and the upward pressure on workers' skills levels (Mander \& Goldsmith, 1996). In contrast, there are those who remain critical and argue that trade liberalisation results in job losses, downward pressure on working conditions and limited opportunity for unskilled workers (Solidar, 2007c; 2007e). Impacts that indicate an improvement in decent work are often framed as 'social upgrading' while any deterioration in decent work is seen to result in 'social downgrading'. Research in this field, while growing, tends to assess the impact of trade liberalisation from a national, sectoral or organisational perspective, while little is known of the workers' perspective. Adopting a worker perspective, this thesis examines the impact of trade liberalisation on decent work among sugar mill workers in the Philippines.

Using a qualitative single case study method, the study draws on the changes in employment and work conditions in a sugar mill when liberal trade policies were introduced. The study uses both primary and secondary data. Primary data were taken from representatives of the workers, the employer and the government sector at national and workplace levels.

The study highlights the trade-offs between indicators of decent work and finds that decent work can be influenced by institutional frameworks in addition to employment strategies. Trade liberalisation resulted in numerical flexibility where permanent workers were reduced while contractual workers were hired as cost reduction measures and a way of avoiding labour laws that are protective of permanent workers. A shift of employment demand toward semi-skilled or skilled workers was also found. Thus, this research directs the attention of future research on trade liberalisation and decent work towards more vulnerable workers such as contractual workers. Furthermore, it highlights the need to increase the coverage of 
legislative protection to include non-permanent workers. Lastly, it challenges the Philippine government to increase the skill level of its workforce to facilitate employment generation. 


\section{Acknowledgments}

This piece of writing would not have been possible without the help and support of many people. Thus, my deepest gratitude goes to ...

- The New Zealand Aid for the support and the opportunity to undertake my MCA degree at Victoria University of Wellington;

- My supervisors, Noelle and Steve for their unending patience, valuable guidance and words of encouragement throughout the ups and downs of my research writing journey;

- The SRA and all the unnamed interviewees especially the management of the sugar mill for their support and cooperation;

- Cherry and the Malata and Gonzales families who have 'adopted' me as part of their respective families in New Zealand and helped me kept my sanity whenever I missed home;

- Lormi Rio who took pains in helping me edit my paper;

- My family and my best friend who all believed in me, supported me, have kept me going and who I will forever hold dear in my heart;

- Most of all, to He who has never failed to catch me every time I fell down - I am eternally grateful to you my Lord and my God. 


\section{Table of Contents}

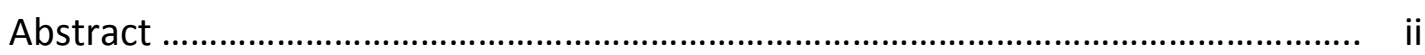

Acknowledgments ............................................................................................ iv

\section{Chapter One - Introduction}

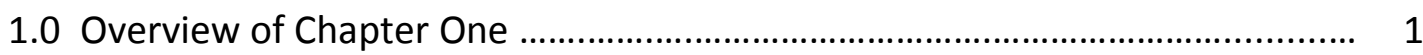

1.1 Economic Globalisation ................................................................................ 1

1.2 The Rationale and Significance of the Research Topic ................................... 2

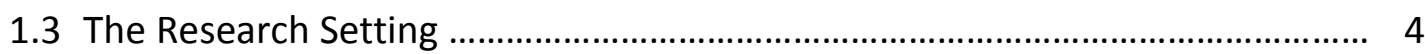

1.4 The Thesis Structure …................................................................................... 5

\section{Chapter Two - Review of Relevant Literature}

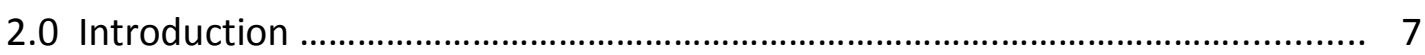

2.1 Trade Liberalisation ...................................................................................... 7

2.2 Economic Upgrading and Social Upgrading …................................................ 8

2.3 The Promotion of Social Upgrading …............................................................. 9

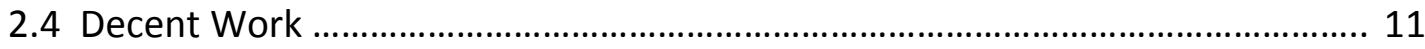

2.4.1 Job Generation and Quality of Employment .......................................... 11

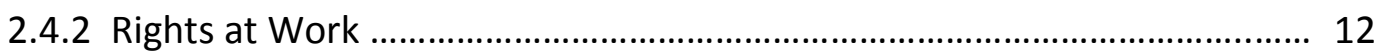

2.4.3 Social Protection ................................................................................. 13

2.4.4 Social Dialogue ..................................................................................... 13

2.5 The Impact of Trade Liberalisation on Decent Work ........................................ 14

2.5.1 The Impact of Trade Liberalisation on Labour Laws and

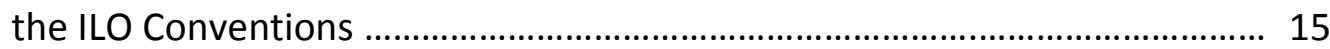

2.5.2 The Impact of Trade Liberalisation on Wages and Employment ........... 17

2.5.2.1 The Variability of Datasources ............................................................. 17

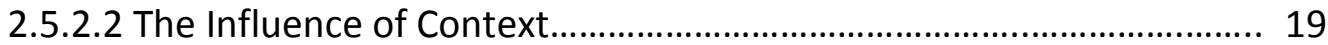

2.5.2.3 Indicators of Trade Liberalisation.......................................................... 19

2.5.3 The Impact of Trade Liberalisation on Working Conditions .................... 20 


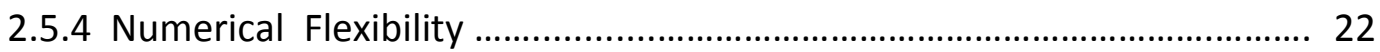

2.6 Effect of Trade Liberalisation in the Philippines ............................................. 24

2.6.1 Employment and Wages ...................................................................... 24

2.6.2 Labour Flexibility and a Shift to Skilled Work .......................................... 25

2.7 Changesin HRM Practices in the Philippines ..................................................... 26

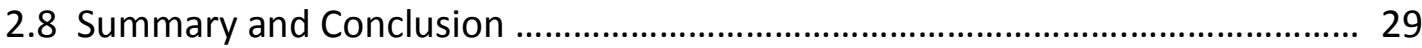

\section{Chapter Three - Methodology}

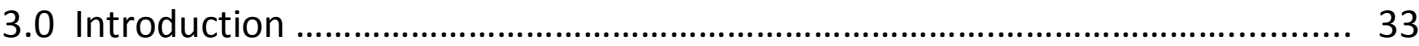

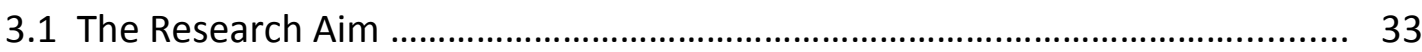

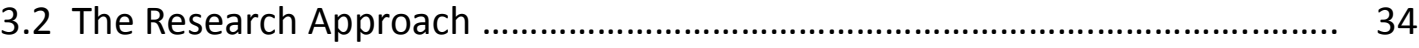

3.2.1 Taking the Qualitative Research Approach ................................................ 34

3.2.2 Using the Single Case Study Method ..................................................... 35

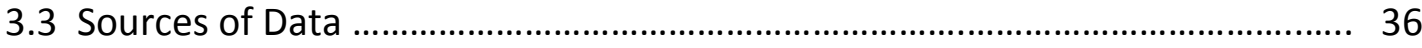

3.3.1 Secondary Sources …........................................................................... 36

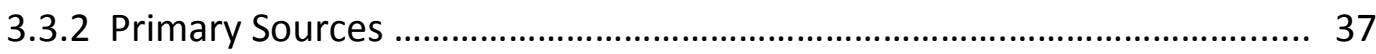

3.4 Constructing the Research Instrument ........................................................... 37

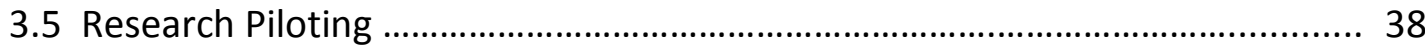

3.6 Identifying and Negotiating Access to Research Site and Respondents ........... 39

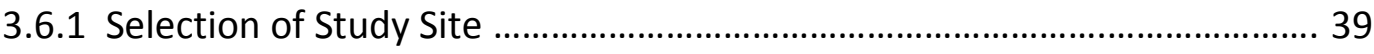

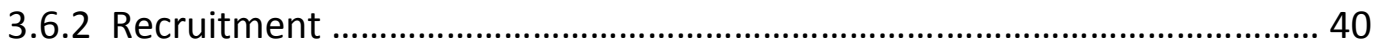

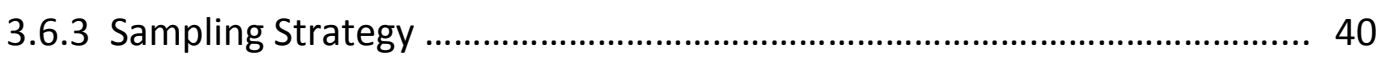

3.6.3.1 Purposive sampling …........................................................................ 41

3.6.3.2 Random sampling ........................................................................ 42

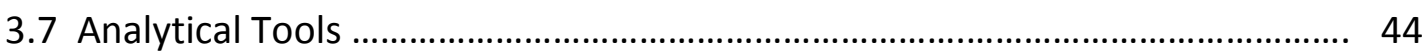

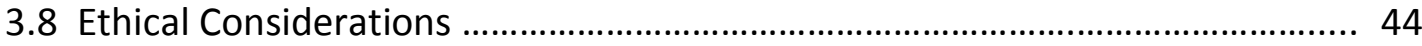

\section{Chapter Four - The Philippine Sugar Industry in Context}

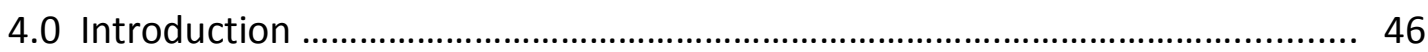

4.1 The History of the Philippine Sugar Industry .............................................. 46 
4.1.1 Phase I - The Development of the Sugary Industry (1500s-1800s) ........ 47

4.1.2 Phase II - US Dependency (1900-1973) ............................................. 48

4.1.3 Phase III - Government Interventions (1974-1985) ............................ 49

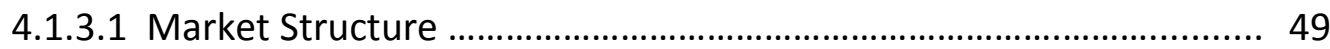

4.1.3.2 Government Interventions .............................................................. 49

4.1.4 Phase IV - Liberalisation and Worker Protectionism (1986-2004) ........ 51

4.1.4.1 The Comprehensive Agrarian Reform Law .................................. 54

4.1.4.2 The Social Security Act of 1997 .................................................. 54

4.1.4.3 The Republic Act of 6982 or the Sugar Amelioration Act of $1991 \ldots . .55$

4.2 The Governance Structure of the Sugar Industry ................................... 57

4.2.1 The Employers' Structure ....................................................................... 57

4.2.2 The Labour Union Structure ............................................................... 59

4.2.3 The Sugar Industry Labour Force .......................................................... 61

4.3 The Sugar Production Process, Classification and Distribution .......................... 62

4.3.1 The Sugar Production Process …................................................................ 62

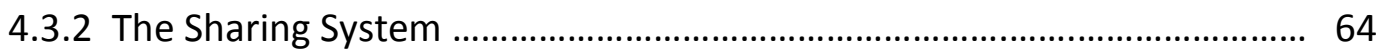

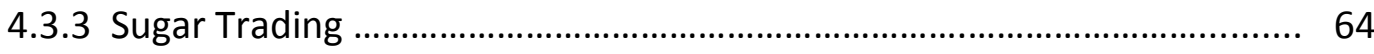

4.3.4 The Sugar Classification System ................................................................ 65

4.4 The Philippine Sugar Industry in the Global Setting ....................................... 68

4.4.1 Trade Distorting Practices .................................................................... 70

4.4.2 The Challenges Faced by the Philippine Sugar Industry ...................... 71

4.5 The Industry's Roadmap to Global Competition ............................................... 72

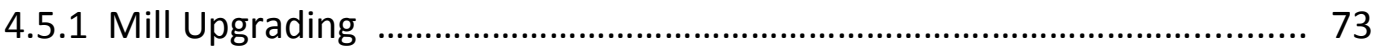

4.5.2 Tapping Other Sources of Revenue of Sugarcane .................................. 73

4.5.3 Sugar Farm Expansion and Increasing Farm Productivity ..................... 74

4.6 Summary of Key Findings …............................................................... 75 


\section{Chapter Five - The Impact of Globalisation on a Philippine}

\section{Sugar Mill: The Case of the Azucarero Sugar Mill}

5.0 Introduction ............................................................................................... 77

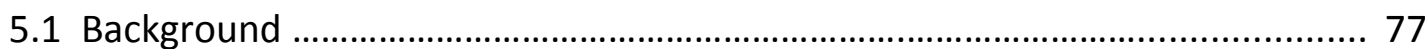

5.2 The Impact of Trade Liberalisation ………...................................................... 79

5.2.1 Technological Changes ......................................................................... 79

5.2.2 Changes in the Structure of Work and the Conditions of Employment..... 81

5.2.2.1 Job Security ……………………………………………………. 84

5.2.2.2 Skills Training and Hiring Qualifications ........................................ 85

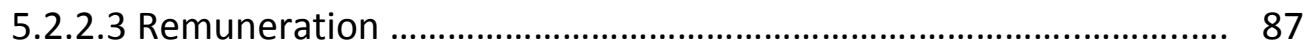

5.2.2.4 Health and Safety .......................................................................... 91

5.2.3 Product and Inter-sectoral Upgarding ……................................................ 93

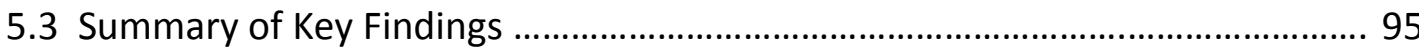

\section{Chapter Six - Discussion and Analysis}

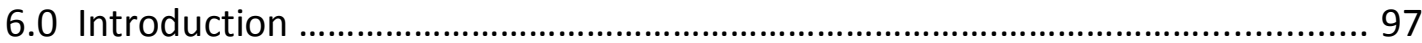

6.1 The Impact of Trade Liberalisation on Decent Work ..................................... 97

6.1.1 Job Generation and Quality of Employment ............................................ 98

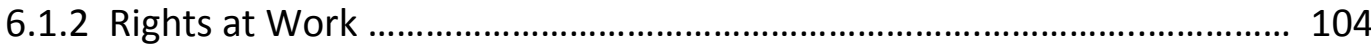

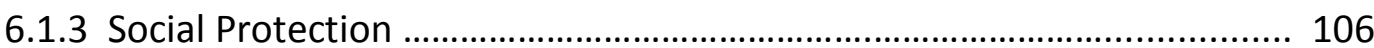

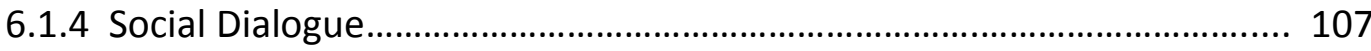

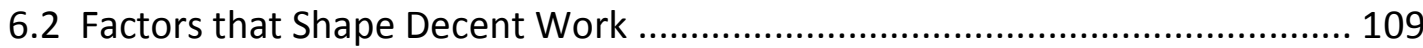

6.2.1 Economic Upgrading …............................................................................ 110

6.2.2 Segmentation of Workers and Numerical Flexibility ............................. 110

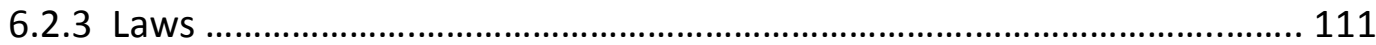

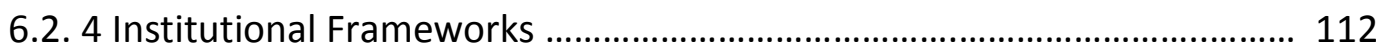

6.3 Trade-offs Between and Amongst Indicators and Aspects of

Decent Work

\section{Chapter Seven - Conclusion and Implications}

7.0 Introduction 


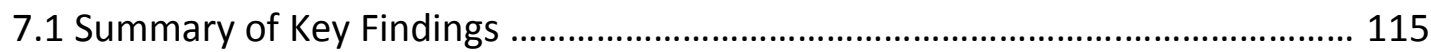

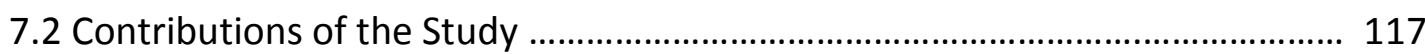

7.3 Reseach Implications and Future Research Agenda ..................................... 118

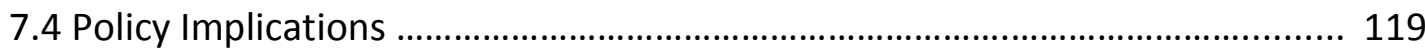

7.4.1 Implications for Workers ………………............................................... 119

7.4.2 Implications for Employers .................................................................. 120

7.4.3 Implications for Government ....................................................................... 120

7.4.2 Implications for the Decent Work Agenda.............................................. 120

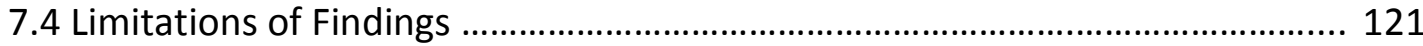

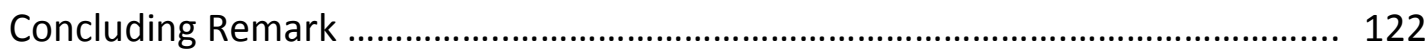




\section{Appendices}

Appendix A - Summary Chart of Literature Reviewed

Appendix B - Questionnaire for the Employers (Sugar Planters and Millers'

Representative .145

Appendix C - Questionnaire for the Labour Union's Representative .147

Appendix D - Questionnaire for the Government Sector Representative 149

Appendix E - Questionnaire for the Mill Managers 151

Appendix F - Questionnaire for the Mill Workers and Supervisors .152

Appendix G - A Copy of the Letter to the Mill 155

Appendix H - A Copy of the Information Sheet for the Private Sector

Respondents .158

Appendix I - A Copy of the Information Sheet for the Government Sector

Respondents 161

Appendix J - A Copy of the Consent Form for the Private Sector Respondents .....164

Appendix K - A Copy of the Consent Form for the Government Sector

Respondents .166

Appendix L - Map of the Philippines Indicating the Location of

Sugar Mills and Refineries 168

Appendix M - Raw Sugar Production Vis-a-Vis Export to the

United States 169

Appendix N - Picture of a Sugar Quedan .170 


\section{LIST OF TABLES AND FIGURES}

\section{Tables}

Table 1. The Impact of Trade Liberalisation on Employment and Wages .17

Table 2. Impact of Trade Liberalisation on Decent Work 20

Table 3. Changes in HRM Practices in the Philippines ................................................ 28

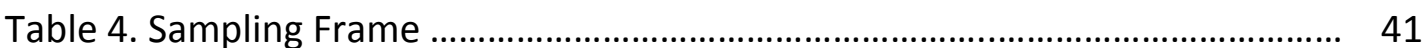

Table 5. The Mill's Workforce Composition ................................................................ 43

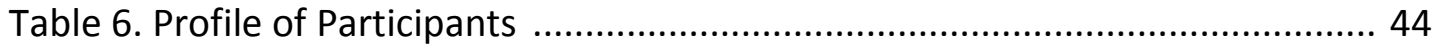

Table 7. Top 15 Sugar (cane) Producers ….............................................................. 69

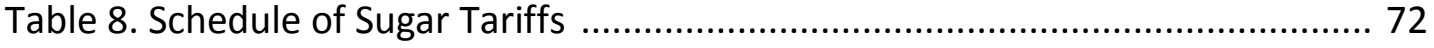

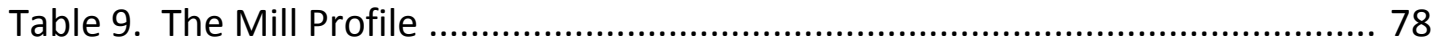

Table 10. Increase in Workers' Wages Versus Average Headline Inflation Rate ..... 88

Table 11. Trade-offs Between and Among Aspects of Decent Work ..................... 113

\section{Figures}

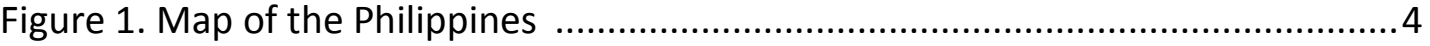

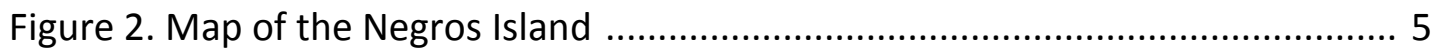

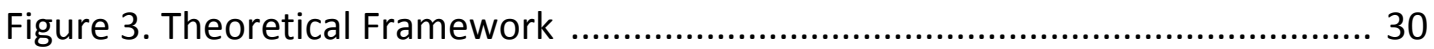

Figure 4. The SRA's Organisational Structure …................................................. 53

Figure 5. The Employers' Policy Consultation Structure ....................................... 58

Figure 6. The Trade Union's Structure Based on Affiliation ................................. 60

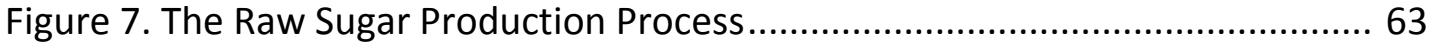

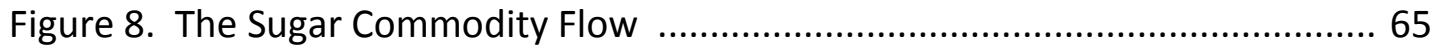

Figure 9. Illustration of the Sugar Classification System ...................................... 67

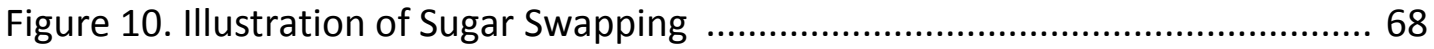

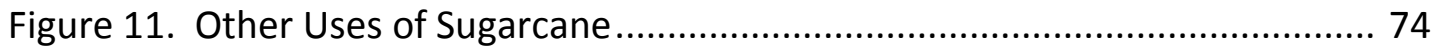

Figure 12. Developed Theoretical Framework ..................................................... 98 


\section{Chapter One \\ Introduction}

\subsection{Overview of Chapter One}

The purpose of this chapter is to introduce the central focus of the thesis which is trade liberalisation and to situate it within the wider context of globalisation. By doing so the chapter identifies some positive and critical views on globalisation through trade liberalisation. The chapter also highlights the rationale of the chosen research topic and narrows the research application by establishing the research site. Lastly, it gives an outline of the research structure.

\subsection{Economic Globalisation}

The process of globalisation has increased the connectedness of countries. While globalisation has economic, political, cultural and social dimensions, this research refers to its economic aspect, particularly focusing on trade and production. Economic globalisation may be described as

an evolutionary process of the integration of world markets, characterised by liberalising economic activities, investment and trade, free flow of production and management factors (Sibao \& Huaer, 2009, p 134).

As a result of the integration of countries, the rapid developments in technology and cheaper transportation costs, international trading can easily be conducted. Thus, governments are now faced with the crucial decision of either opening their doors to free trade through liberal trade policies (trade liberalisation) or constrain importation through import barriers such as tariffs and quantitative limitations of imports. However, the decision is not one that is simply dependent upon the internal environment of the country but is also influenced by external trade pressures. 
The positive view of globalisation through trade liberalisation is basically premised on the positive relationship between trade growth and economic growth (Dollar, 1992; Harrison, 1996). Hence, from this assumption, proponents of trade liberalisation conclude that economic growth is good for the poor as it generates jobs and alleviates poverty (Lee \& Vivarelli, 2006). Others claim that trade liberalisation leads to resource allocation efficiency (Camdessus, 1996) because countries can focus on industries with which it has comparative advantage while import products or services that are costly to produce in its locality. Goods are becoming more accessible while workers' skills are improving (Mander \& Goldsmith, 1996). On the other hand, the critical view argues that globalisation has brought uneven effects (Osland, 2003; World Commission on the Social Dimension of Globalisation $^{1}$ (WCSDG), 2004). It is disadvantageous to workers of newly developed industries and small enterprises which could not compete with multinationals in terms of capitalisation and investment (WCSDG, 2004). In view of this, it becomes important that trade liberalisation should be examined alongside decent work. It is in this topic of debate that this study situates itself.

\subsection{Rationale and Significance of the Research Topic}

Determining the impact of trade liberalisation on workers in the Philippine sugar industry is very relevant today. The sugar industry is one of the governmentprotected industries in the country. Domestic sugar producers are not able to compete with other more cost-efficient sugar producing countries, hence high sugar tariffs serve as their means of defense against international competition. However, the Philippine government has committed to reduce sugar tariffs from 50\% in 2003 to 5\% in 2015 (Philippine Government, 2010). With the reduction of sugar tariffs, it is therefore imperative to understand the effect of trade

\footnotetext{
${ }^{1} \mathrm{~A}$ commission created by the ILO to look at how the positive effects of trade liberalisation will be distributed more equitably among the peoples. More information about this commission may be found in ILO's website (www.ilo.org).
} 
liberalisation on workers to determine if government interventions are possible and needed.

The continued debate between the positive and the critical views on the impact of trade liberalisation is partly because of limited empirical evidence (Leisink, 1999). However, despite the uncertain impact, developing countries such as the Philippines (Orbeta, 2002) have introduced liberal trade policies partly because many have considered trade liberalisation as key to economic development of developing countries (Lall, 2003). However Lall claims that the success of countries that have opened themselves to global trade was not simply an automatic result but a product of several factors such as government policies and the ability of local industries to compete globally. Hence, until the impacts of trade liberalisation in this country are determined, the Philippine government is intensely exposing its local industries to global competition for unknown results. Furthermore, with better understanding of the impact of trade liberalisation, governments can create policies that facilitate an economic environment for the local industries to be able to compete internationally and will have minimal social disturbance in the process of resource allocation. Thus, the issue of determining the impact of trade liberalisation on workers becomes more pressing for policy implication purposes.

Moreover, most of the arguments advanced by the critics of trade liberalisation relate to its negative impact on workers. Yet, despite the abundance of literature on trade liberalisation, there is limited research from the workers' perspective. To a large extent, the literature generally provides national accounts of the effect of trade liberalisation on a country's economic growth and employment and wage levels. Additionally, much of the literature is quantitative in nature, hence it does not take into account the factors that further influence the impact of trade liberalisation on workers. In the Philippine literature, there is inadequate research towards understanding the impact of trade liberalisation on work conditions and much less research done at the workplace level and in only involving very few industries. Amongst the industries that lack such research is the sugar industry. Thus, this research attempts to provide additional empirical evidence on the impact 
of trade liberalisation from a workers' perspective within the Philippine sugar industry taking on a qualitative approach.

\subsection{The Research Setting}

This research is situated in the Philippines, a developing country in Southeast Asia (Figure 1 shows a map of the Philippines). The Philippines has a total area of about 300,000 square kilometres scattered into more than 7,100 islands (Philippine Department of Tourism, n.d.). It is divided into three island groups namely: 1) Luzon, which is the northern part of the island; 2) Visayas, which is the central part; and 3) Mindanao, which is the southern part. While the national language is Filipino, many dialects are used in different regions.
Figure 1. Map of the Philippines

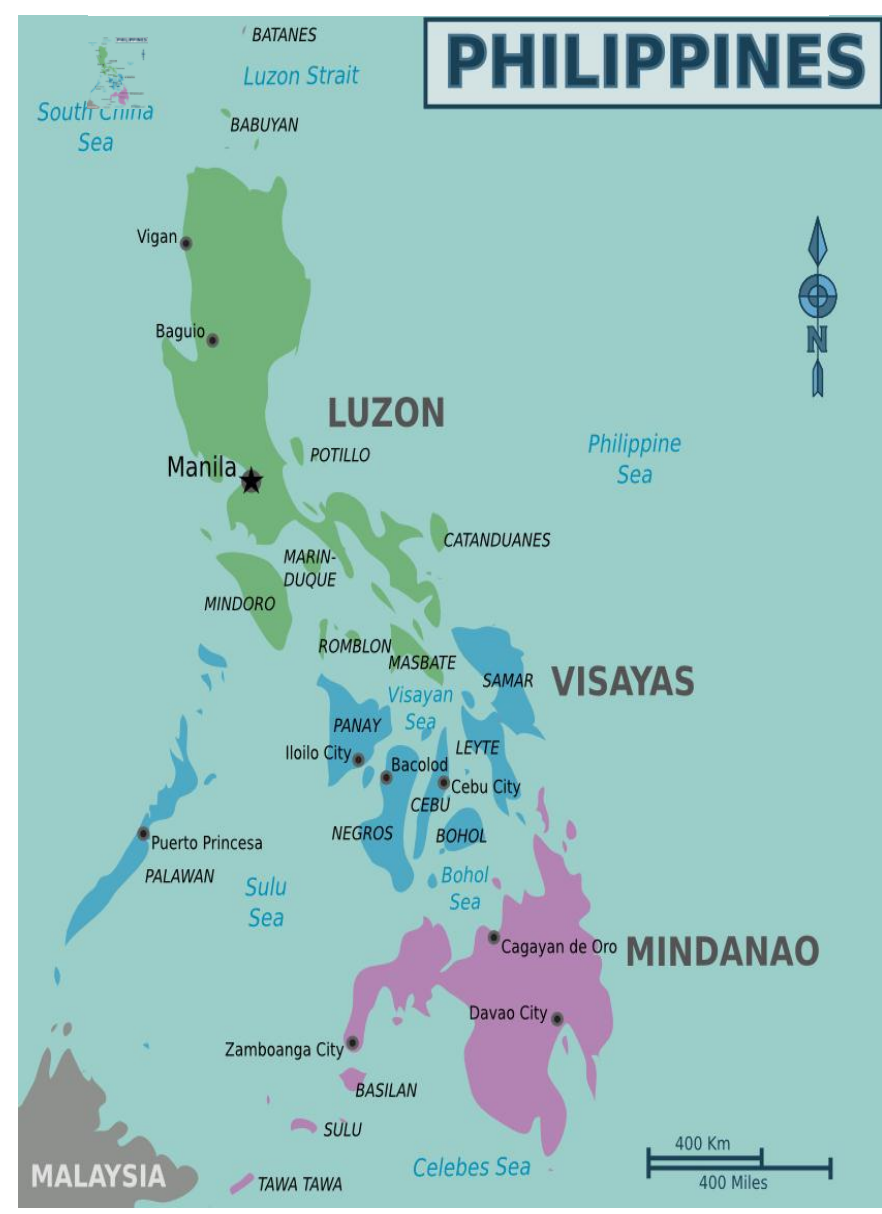

Source: Philfaca.com (n.d.)

This study involves the Philippine sugar industry and its major industrial relations actors: the employer, the workers, and the government. Employers in the sugar industry are the sugarcane farmers (commonly referred to in the Philippines as 'the sugar planters') and the millers. Workers on the other hand are the sugar mill and sugar farm workers. The focus of this case study are the sugar mill workers of a sugar mill situated in Negros Occidental. Negros is an island situated in the Visayas area and is divided into the Occidental and the Oriental region (See Figure 2 for a map of Negros). Negros Occidental is the home of the majority of the sugar mills in 
the country and hence was chosen as the study site. The dialect used in that area is Hiligaynon.

Figure 2. Map of the Negros Island

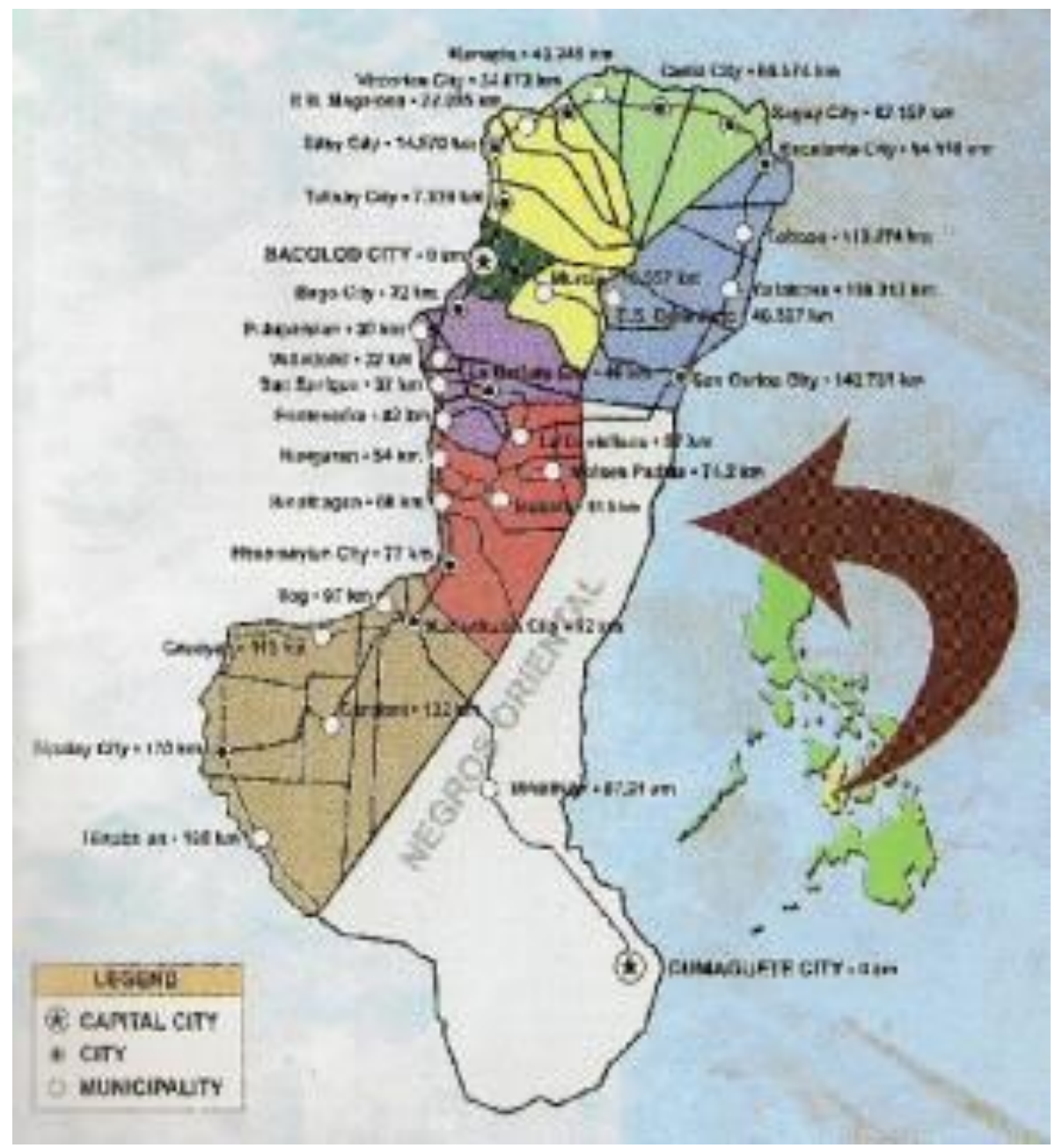

Source: Negros Occidental Tourism (n.d.)

\subsection{Thesis Structure}

The thesis is composed of seven chapters. Chapter Two presents a review of the relevant literature regarding trade liberalisation and its economic and social effects. It focuses on the work conditions of workers and discusses the impact of trade liberalisation on decent of work. Chapter Three outlines the research methodology employed in this research. It presents the research aim which is "to explore the impact of trade liberalisation on decent work among sugar mill workers in the 
Philippines". The chapter also enumerates the research question and sub-questions. Chapters Four and Five presents the findings. Chapter Four reveals the data gathered from the national level, reporting about the sugar industry in the global setting and narrowing it to the local (national) setting. Chapter Five presents the changes in employment and work structure in a sugar mill as a result of the employer's efforts to become cost competitive. Chapter Six discusses and analyses the findings in relation to the related literature and in the process answers the research questions. Lastly, Chapter Seven summarises the key findings and contributions of the study, indicates the research and policy implications and enumerates future research agenda. The research is then ended with the researcher's concluding remark. 


\section{Chapter Two}

\section{Literature Review}

\subsection{Introduction}

The importance of determining the social effects of trade liberalisation specifically on workers and their work conditions leads this chapter to examine the literature relating to the impact of trade liberalisation on decent work with a view to establish a framework for examining the impact of trade liberalisation (A summary chart of the literature reviewed on trade librealisation according to topic is attached as Appendix A. A-1, A-2, A-3 and A-4) on workers' conditions. In keeping with this purpose, the chapter first points to a working definition of trade liberalisation and presents how existing research has operationalised trade liberalisation. Second, the chapter underscores the economic and social effects of trade liberalisation and narrows it to the social aspect particularly on decent work which is the focus of this research. Third, the chapter takes on the International Labour Organization's definition of what are acceptable work conditions that result in 'decent work'. Empirical studies are reviewed to show how the different impacts of trade liberalisation on decent work are carried out at different levels (national, industry, plant and worker levels).

\subsection{Trade Liberalisation}

Trade liberalisation is a process that has been adapted by many countries who perceive it to be a key part of an economic development process because it brings employment and economic growth (Lall, 2003). Research has defined trade liberalisation in several ways with little consensus (Greenaway \& Morrissey, 1994). In keeping, research has referred to trade liberalisation as 1 ) tariff reductions and the removal of import restrictions (Feliciano, 2001; Revenga 1995), whether fully or partially; 2) the termination of preferential agreements (Hunt, Lahlou, Musette \& 
Chourou, 2007; Robertson, Sitalaksmi, Ismalina \& Fitrady, 2009); or 3) the use of export and import growth factor (Barrientos, Gereffi \& Rossi, 2010; Bernhardt \& Milberg, 2011; Theron, Godfrey \& Visser, 2007; Serrano, 2007). Based on these different indicators of trade liberalisation, it could be argued that trade liberalisation refers to a process of trade reforms that bring the prices of domestic imports and exports closer to world market prices (Morrissey, 1995). It is from this working definition of trade liberalisation that this research begins.

\subsection{Economic and Social Upgrading}

Trade liberalisation has various effects especially at the workplace level (SAPRIN, n.d., Solidar, ${ }^{2} 2007$ c; 2007e). It facilitates economic upgrading and social upgrading. In general, economic upgrading refers to the improvement of products or its production processes with the goal of cost-efficiency and maximising revenue (Pietrobelli \& Rabellotti, 2006). The literature has identified four methods of economic upgrading namely: 1) process upgrading which involves improvements in the production processes or the use of more advanced technology; 2) product upgrading or adding value to existing products; 3) functional upgrading which happens when the firm moves up the commodity chain; and 4) inter-sectoral upgrading which involves the entry to a new industry or sector (Gereffi, 1999; Humphrey \& Schmitz, 2002). In contrast, social upgrading is focused on improving the lives of workers and their work conditions (Milberg \& Winkler, 2008).

In relation to economic upgrading, Morrissey (1995) reports that many economists have established a strong case for trade liberalisation as a path towards economic development. As a consequence, he continues, countries have, on their own or as part of the World Bank Structural Adjustment Programme, instituted trade reforms towards liberalisation.

\footnotetext{
${ }^{2}$ Formerly International Workers Aid and is conventionally associated with workers movements. Among its current focus is the putting up of civil society policy positions at the European level. More information about Solidar can be obtained from their website www.solidar.org
} 
Due to trade liberalisation, international competitiveness has become the main focus of companies (Held, 2004). In the process, Gereffi and Korzeniewicz (1994) note that companies have resorted to segmenting their production systems and relocating sections of the system to different localities, within and outside the country, where it is cost efficient. This resulted in the creation of global commodity chains. Along the commodity chain, they explain that products may be 'producerdriven' or 'buyer-driven'. In the producer-driven industries, the main producer exercises control over small sub-manufacturing firms in the production process. In the buyer-driven industries on the other hand, the network of marketing firms that links the producer of goods to the retailers exercises influence over producers. (Gereffi \& Korzeniewicz, 1994). Furthermore, there is no significant barrier in the entry of sugar production.

Economic upgrading, represented by increases in productivity, in relation to social upgrading, has been found to increase wages (Flanagan, 2005). In addition, studies by the ILO (2006) and Deshingkar (2009) have found that buyer-driven requirements often drive social upgrading. The link between economic upgrading and buyer-requirements in relation to social upgrading implies that these issues have a direct impact on social upgrading. However, the complexity of the relationships between these variables with regard to social upgrading is better dealt with in separate research. What is relevant in relation to this present research is to recognise that the economic upgrading strategies of a firm and the buyers' influence may, in addition to trade liberalisation, shape social upgrading.

\subsection{The Promotion of Social Upgrading}

The effect of trade liberalisation with respect to workers and their conditions at work remains a heated topic of debate in the literature. According to Pereira (2010) proponents of pro-trade liberalisation argue that trade liberalisation reduces poverty and inequality. In contrast, Camdessus (1996) of the International 
Monetary Fund (IMF) contends that the opening of trade reveals real prices and hence, facilitates the efficient allocation of resources. He further maintains that competition, as a result of free trade, motivates firms to be more efficient and consequently become internationally competitive. According to the International Chamber of Commerce (ICC), the result of being internationally competitive has generated millions of jobs (Kelly \& Prokhovnik, 2004). Hence, figures from the American Foreign Policy Association (2002) for the period 1998-2000 indicate that, the more globalised a nation is, the greater the level of income compared to less globalised nations.

However, even within globalised nation, trade liberalisation has increased inequality because it tends to benefit capital significantly more than labour (Safa, 2002). Conversely, the anti-trade liberalisation view is that trade liberalisation has increased human rights violations (Pereira, 2010). In expressing the same view, O'Connell (2010) explains that human rights are facilitated by government interventions. However, the trend of trade liberalisation, deregulation and privatisation has taken social services away from government to private institutions. As a result, services have been commercialised, thereby depriving the less fortunate from being beneficiaries of these services (O'Connell, 2010). In keeping with the anti-trade liberalisation view, Ranney and Naiman (1997), reject the argument that job generation is a likely result of trade liberalisation. Ranney and Naiman contend that there is no incentive-let alone, a mandate-for employers to share the benefits of higher productivity derived from freer trade with their workers. They are therefore implying that, even if companies generate more income from trade liberalisation, this will not automatically lead to improved conditions for workers.

The WCSDG (2004) while recognising the benefits of trade liberalisation, also states that it has resulted in uneven social and economic effects among and within countries. Although trade liberalisation has been economically favourable to some countries because of market expansion, the Commission posits that some trade agreements may be biased against less developed countries that are still in the process of developing certain industries. It expressed concern that the further 
opening of global trade may have a drastic effect on those industries especially and in particular, workers in those sectors. "Global imbalances are morally unacceptable and politically unsustainable", reported the Commission (2004, p.X). Thus, to ensure that workers also benefit from trade liberalisation, the IMF has incorporated social upgrading in its programmes. However, Solidar (2007a) believes that the IMF's priority remains focused on economic development. Consequently, if budget cutbacks are taken, funds for basic social protection or services for workers are drastically affected (Solidar, 2007a).

\subsection{Decent Work}

Central to the current debate on social upgrading is the notion of 'decent work'. In investigating social upgrading, it is imperative to first determine what constitutes 'decent work'. The ILO defines decent work as work "under conditions of freedom, equity, security and dignity, in which rights are protected and adequate remuneration and social coverage is provided" (Barrientos, 2007, p.1). In relation to this, a large body of literature has examined decent work by determining its indicators.

In examining decent work, the ILO proposed the four aspects that should be given emphasis. These are known as the 'four pillars of decent work' (ILO, 2012b). ${ }^{3}$ The interdepence of these pillars or aspects must be examined in order to provide a holistic approach (Macnaughton \& Frey, 2011).

\subsubsection{Job Generation and Quality of Employment}

The ILO (2012b) identifies job generation and the quality of employment as the first aspect of decent work. This stresses that having a job is the primary consideration

\footnotetext{
${ }^{3}$ These aspects of work have been used as lenses in research that examines decent work such as Godfrey (2003), regarding the dimension of decent work; ILO, 2003, which examined decent work in agriculture; and MacNaughton \& Frey (2011) who explored decent work as a human rights approach.
} 
and followed by work conditions. Existing research (Ghai 2003, Anker, Chernyshev, Egger, Merhran \& Ritter, 2003) generally measures job generation by employment or unemployment rate. However, Ghai (2003) relays that job generation should also consider the quality of the job. He suggests that the greater challenge for job generation lies not only in having available jobs for workers but in the creation of quality employment. Several authors (Anker, Chernyshev, Egger, Merhran \& Ritter, 2003; Bonnet, Figueiredo \& Standing, 2003; Ghai, 2003; Kuruvilla, 2006) suggest that social upgrading within the quality of employment can be seen through the following indicators:

1. Adequate wages (wages should be at least above the poverty threshold of \$2 per day per person or above the national poverty line);

2. Balanced (not excessive) work hours;

3. Allowance for paid leave;

4. Provisions for training;

5. Existence of health and safety programmes;

6. Job security by determining whether work is temporary or permanent.

In examining the quality of employment, Ghai (2003) notes that it is affected by differences in the nature and structure of work, season and consumer demand (local and international). As such, some types of employment are secure, safe and well compensated while others are less secure, prone to accidents and less compensated (Ghai, 2003).

\subsubsection{Rights at Work}

The ILO (2012b) considers rights at work as the second aspect of decent work. Ghai (2003) points out that the agenda on guaranteeing rights at work facilitates that workers, especially those who are disadvantaged are provided with rights that will protect them from exploitation. Many authors recommend that social upgrading with respect to rights at work can be established by granting workers the right to form unions or associations free from harassment or discrimination (Anker, Chernyshev, Egger, Merhran \& Ritter, 2003; Bonnet et al., 2003). However, after providing these rights, Ghai (2003) stresses that the real challenge is ensuring that 
workers' rights are respected. Ghai points out that most workers are not in a position to demand their rights. He relays that this is particularly true for unskilled workers where employers can easily replace them from a supply of unemployed workers. Thus, in addition, rights at work can also be measured by determining how effective these rights are implemented as well as the existence of mechanisms and access to institutions to address redress of rights (Anker, Chernyshev, Egger, Merhran \& Ritter, 2003; Bonnet et al., 2003; Ghai, 2003; Kuruvilla, 2006). In relation to this, Barrientos (2007) and Deshingkar (2009) also emphasise the vulnerable situation of workers who are not even aware that they have demandable rights.

\subsubsection{Social Protection}

The ILO (2012b) reports that the third aspect of decent work is concerned with providing social protection. Both Saith (2004) and Ghai (2003) refer to this as the protection afforded to workers and their family from the risk of unemployment, illness or disability and old age. Saith contends that this view is justified by the principle that it is a person's basic right to be secured not only of one's life but also of one's livelihood. Yet, despite the importance of social protection, labourers especially in the informal economy have no social protection (Lund \& Srinivas, 2000). Thus, to further this agenda, several authors suggest to operationalise social upgrading with respect to social protection by identifying: 1) the existence of social protection programmes; 2) the coverage of social protection; and 3) sufficient amount of public expenditure on social security programmes, among others (Anker, Chernyshev, Egger, Merhran \& Ritter, 2003; Bonnet et al., 2003; Ghai, 2003; Kuruvilla, 2006).

\subsubsection{Social Dialogue}

The promotion of social dialogue is the fourth aspect of decent work identified by the ILO. Kuruvilla (2006) explains that social dialogue includes

all types of negotiation, consultation or simply exchange of information between, or among, representatives of governments, employers and workers, on issues of common interest relating to economic and social policy (p.178). 
Kuruvilla further states that social dialogue can be between management and labour (bipartite) or together with government's participation (tripartite). The process may be formal or informal and may take place at different levels (national, regional or at the enterprise level). It can also be on a sectoral or inter-sectoral level. In social dialogue, all parties concerned are encouraged to be involved so that a common agreement can be achieved under conditions of equal representation (Kuruvilla, 2006). Thus, social upgrading with respect to social dialogue may be measured by: 1) union density; 2) the existence of collective agreements; 3 ) collective bargaining coverage rate; and 4) the existence of tripartite consultations (Anker, Chernyshev, Egger, Merhran \& Ritter, 2003; Bonnet et al., 2003; Ghai, 2003; Kuruvilla, 2006). However, Kuruvilla (2006) cautions that these indicators have their own limitations. For instance, while collective bargaining agreements are indicators of social dialogue, some workers such as those in the informal sector, are not represented in negotiations (Kuruvilla, 2006). Likewise, Ghai (2003) further adds that bargaining agents may not effectively represent the 'voice' of the workers before employers and the government.

\subsection{The Impact of Trade Liberalisation on Decent Work}

A number of authors have examined the impact of trade liberalisation on some aspects of decent work (Balotra, 2003; Cling, Razafindrakoto \& Roubaud, 2009; Locke, Qin \& Brause, 2006; Neak \& Robertson, 2009; Solidar, 2007b, Solidar, 2007c). These were conducted in various developing countries and mostly at the national and industrial levels. A variety of empirical studies claim that trade liberalisation has: 1) led to the violations of labour laws and International Labour Law Conventions; 2) caused different impacts on employment demand and wages; 3) caused uneven effect on work conditions; and 4) brought about numerical flexibility. The next subsection briefly discusses each of these results. 


\subsubsection{The Impact of Trade Liberalisation on Labour Laws and the ILO Conventions}

A number of case studies reveal that trade liberalisation has resulted in violations of labour laws and ILO Conventions. Ghai (2003) notes that the ILO, in providing acceptable labour conditions, has mainly relied on government legislation consistent with the government ratified ILO conventions. However, others find that government laws and ratifications of ILO conventions on its own, have failed to improve work conditions (Cling et al., 2009; Solidar, 2007b).

For example, a case study in Guatemala and Nicaragua reports that these countries have ratified many ILO Conventions (Solidar, 2007b). These include among others, conventions concerning minimum age for admission to employment, discrimination in respect of employment and occupation and freedom of association and protection of the right to organise. These are rights granted to workers and theoretically are indicators in the category of rights at work. On the face of it, these are seen to provide decent work. However, information at the plant level points out violations contravening these conventions such as child labour and discrimination against migrant workers which were rampant and higher within the export processing zones (EPZ).

The study also stresses that the ratification of several ILO Conventions and the enactment of labour laws against union membership discrimination in Guatemala and Nicaragua did not stop employers from terminating workers who joined the labour union and who in fact, circulated a black-list of union members among employers (Solidar, 2007b). Similarly, the research study by Cling et al. (2009) in Madagascar discloses that despite the fact that the government has granted workers with the constitutional freedom to form association and bargain collectively with employers, union density remains very low (14\% in EPZ and $10 \%$ in the rest of Madagascar). They imply that since collective bargaining is done through the union, it means that coverage of a collective bargaining agreement (CBA) is very limited. In the same context, Wood, Harcourt and Harcourt (2004) who examined age-related questions from application forms taken from different 
companies in New Zealand, conclude that workers remained discriminated against because of being older, despite the law against age discrimination at work.

These studies suggest that the implementation of labour laws remains a problem. Thus, it can be seen from the literature that good labour laws and ratification of ILO Conventions do not guarantee decent work. In contrast, it suggests that there is a need to monitor whether these laws and conventions are actually being complied with at the workplace. Furthermore, the existence of CBAs alone does not automatically lead to decent work for all workers. Examining the existence of CBA as an indicator of decent work should be taken together with other indicators such as union density or the number of workers the agreement applies to.

Continuing with the issue on the implementation of labour laws, there are several factors that shape its effective implementation. For instance, the Venezuelan study suggests that compliance and applicability of the law may differ according to the locality and nature of work or the status of employment (Quijada, 1979). In the same line, Piore and Schrank (2006) state that in the Dominican Republic, different monitoring styles were needed to facilitate the implementation of labour standards. Locke et al. (2006) further add that even at a plant level, the companies' management monitoring style was found to have little influence on compliance with labour standards. A solution to this problem on implementation was found in the research of Solidar (2007c) and Neak and Robertson (2009). Their studies report that labour laws became effective when decent work was integrated as part requirement of the US market and this was followed by inspections made by the ILO officials. This means that for products which belong to buyer-driven industries, buyer-requirement may facilitate decent work. Thus, in exploring the impact of trade on decent work, there may be a need to highlight possible differences in the impact of labour laws and buyer-driven requirements on different types of workers within the same industry. 


\subsubsection{The Impact of Trade Liberalisation on Wages and Employment}

The impact of trade liberalisation on decent work is contingent on various factors (Revenga, 1995; Feliciano, 2001; Solidar, 2007e). This can be seen through a number of studies conducted across several sectors in different developing countries (see Table 1). These studies focused on the impact of trade liberalisation on wages and employment, the results of which paint an inconclusive picture. The disparity in results was due to the differences in the source of data, the variation in context and the indicators of trade liberalisation.

Table 1. The Impact of Trade Liberalisation on Employment and Wages

\begin{tabular}{|c|c|c|c|c|c|c|}
\hline \multirow[b]{2}{*}{ SOURCE } & \multirow[b]{2}{*}{ COUNTRY } & \multicolumn{2}{|c|}{ EFFECT ON } & \multirow{2}{*}{$\begin{array}{c}\text { SOURCE } \\
\text { OF } \\
\text { DATA }\end{array}$} & \multirow[b]{2}{*}{$\begin{array}{l}\text { SECTOR OR } \\
\text { INDUSTRY }\end{array}$} & \multirow{2}{*}{$\begin{array}{c}\text { REMARKS/ } \\
\text { OTHER } \\
\text { FINDINGS }\end{array}$} \\
\hline & & $\begin{array}{c}\text { EMPLOY- } \\
\text { MENT }\end{array}$ & WAGES & & & \\
\hline $\begin{array}{c}\text { Revenga } \\
(1995) \\
\end{array}$ & Mexico & decrease $^{*}$ & increase $^{*}$ & Firm-level & Manufacturing & $\begin{array}{l}\text { Increased } \\
\text { wage inequality }\end{array}$ \\
\hline $\begin{array}{l}\text { Feliciano } \\
(2001)\end{array}$ & Mexico & $\begin{array}{l}\text { no } \\
\text { significant } \\
\text { noffect } \\
\text { no } \\
\text { significant } \\
\text { effect* }\end{array}$ & $\begin{array}{l}\text { no } \\
\text { significant } \\
\text { effect }^{*} \\
\text { decrease }^{* *}\end{array}$ & Industry-level & & $\begin{array}{l}\text { Increased } \\
\text { wage inequality }\end{array}$ \\
\hline $\begin{array}{c}\text { Milner \& } \\
\text { Wright } \\
(1998) \\
\end{array}$ & Mauritious & Increase & & Industry-level & All sectors & \\
\hline $\begin{array}{c}\text { Cling, } \\
\text { Razafindrakoto } \\
\text { \& Raubaud } \\
\text { (2009) }\end{array}$ & Madagascar & Increase & & Industry & $\begin{array}{l}\text { Export } \\
\text { Processing } \\
\text { Zone }\end{array}$ & $\begin{array}{l}\text { wages are lower } \\
\text { compared to } \\
\text { other industrial } \\
\text { Sector }\end{array}$ \\
\hline $\begin{array}{c}\text { Bahlotra } \\
(2003)\end{array}$ & India & Decrease & increase & National-level & All sectors & \\
\hline $\begin{array}{c}\text { Bernhardt \& } \\
\text { Milberg } \\
(2011)\end{array}$ & $\begin{array}{l}\text { Africa, Asia, } \\
\text { Latin America \& } \\
\text { the Caribbean }\end{array}$ & Increase & increase & National-level & $\begin{array}{l}\text { Apparel, mobile } \\
\text { phone, agro foods } \\
\text { \& tourism sectors }\end{array}$ & $\begin{array}{l}\text { No increase in } \\
\text { wages in the } \\
\text { tourism sector }\end{array}$ \\
\hline
\end{tabular}

* In relation to tariff reduction

** In relation to reduction in import license

Source: See first column

\subsubsection{The variability of datasources}

Different sources of data can result in differences in the impact of trade liberalisation. As table 1 shows, the research by Revenga (1995) and Feliciano 
$(2001)^{4}$ both examined the effects of tariff reductions and relaxed import requirements in relation to employment demand and wages in Mexico. However, Revenga (1995) utilised data at the firm-level (involving various firms in an industry) while Feliciano used industry data (involving various industries). As a result, the two studies ended up with slightly different findings. Revenga (in the manufacturing industry) found a moderate decrease in employment as a result of reduction in tariff rates and quota coverage while in Feliciano's study, national employment was not significantly affected by tariff reduction. For wages, the Bahlotra study showed that a reduction in tariff levels resulted in an increase in average wages, while Feliciano's study reported no significant effect on wages. Justifying the differences in her findings from that of Feliciano, Revenga pointed out that changes in some industries were not significant enough to affect the aggregate industry which explains the differences in the findings when data is sourced from different levels (net industry employment versus firm-level employment). Thus, it can be implied that the aggregate impact of trade liberalisation may be dependent upon where the source of data (national, industry or workplace level) is gathered.

Similarly, among call centres in the Philippines, although increased employment was found at the industry level, the author also found a high turn-over rate (Solidar, 2007e). The workers explained that they hop from one call centre to another in search of higher salary and better working conditions. The high demand of labour at call centres and the limited quantity of qualified workers have given the workers ease in transferring from one firm to the other. Solidar therefore raises the issue as to whether the data showing increased in employment, taken from the industry level, is accurate considering that it has not taken into account the rapid resignation of workers. The high turn-over rate may therefore mean that the same workers who resigned from work have simply transferred to another firm, yet the industry data has plainly recorded it as an increase in employment. Hence, Kelly (2001) maintains that workers should not be merely seen as victims or beneficiaries of

\footnotetext{
${ }^{4}$ Feliciano's (2001) research was conducted earlier than Revenga (1995) but was published at a later date.
} 
trade liberalisation but as active players who influence the dynamics of the changing work conditions. The authors are therefore stressing that future research take into consideration the influence of key players of the industry under investigation.

\subsubsection{The influence of context}

The context of the industry or firm may also influence the impact of trade liberalisation. The influence of industry was illustrated in the cross-country analysis on the impact of trade liberalisation on wages and employment between Africa, Asia, Latin America and the Caribbean involving four industries (apparel, mobile phone, agro foods and tourism) (Bernhardt \& Milberg, 2011). The research shows that the tourism industry did not produce the same result as the other three industries which reflected an increase in employment demand and real wages due to growth in the export market. The variation in results finds explanation in arguments in literature claiming that the variable impact of trade liberalisation on decent work may be attributed to the diversity of the market environment surrounding the industry or nation under examination (Currie \& Harrison, 1997; Barrientos et al., 2010). Thus, the impact of trade liberalisation on decent work is context dependent.

\subsubsection{Indicators of trade liberalisation}

The impact of trade liberalisation also depends on global indicators of trade liberalisation. For instance, increase in export market has shown to boost employment (Cling, et al., 2009; Bhalotra, 2002). However, reductions of import protection measures produced the opposite result (Milner \& Wright, 1998; Revenga, 1995). In addition, the termination of preferential trade agreements, as an indicator of trade liberalisation, have been shown not only to stagnate wages and benefits but also workers' training in the textile industry in Indonesia (Robertson, Sitalaksmi, Ismalina \& Fitrady, 2009). This implies that liberal trade policies positively affects employment generation of the export-oriented industry while it negatively affects employment generation of protected industries. 


\subsubsection{The Impact of Trade Liberalistion on Working Conditions}

Trade liberalisation has resulted in a decline in work conditions (social downgrading) in many developing countries. This claim is substantiated in the case studies of Solidar (2007b; 2007c; 2007d; 2007e) who examined the decency of work conditions in six countries, involving different sectors which manufacture products or provide services for export. These include the asparagus industry in Peru and Chile (Solidar, 2007d) the free trade zone in Guatemala and Nicaragua (Solidar, 2007b) the textile industry in Cambodia (Solidar, 2007c) and the call centre in the Philippines (Solidar, 2007e). Table 2 summarises the findings of the Solidar case studies, indicating whether the impact of trade liberalisation on decent work is positive or negative.

Table 2. The Impact of Trade Liberalisation on Decent Work.

\begin{tabular}{|l|l|l|l|l|l|l|l|l|}
\hline $\begin{array}{c}\text { SOURCE } \\
\text { Solidar }\end{array}$ & COUNTRY & $\begin{array}{c}\text { EMPLOY- } \\
\text { MENT }\end{array}$ & WAGES & $\begin{array}{c}\text { WORK } \\
\text { HOURS }\end{array}$ & $\begin{array}{c}\text { JOB } \\
\text { SECURITY }\end{array}$ & $\begin{array}{c}\text { FREEDOM } \\
\text { OF ASSO- } \\
\text { CIATION }\end{array}$ & HEALTH & SAFETY \\
\hline $2007 \mathrm{~b}$ & Guatemala & Positive & Negative & & Negative & Negative & & \\
\hline $2007 \mathrm{~b}$ & Nicaragua & Positive & Negative & & Negative & Negative & & \\
\hline $2007 \mathrm{c}$ & Cambodia & Positive & Negative & Negative & & Negative & Negative & Negative \\
\hline $2007 \mathrm{~d}$ & Peru & Positive & Negative & Negative & Negative & Negative & & \\
\hline $2007 \mathrm{~d}$ & Chile & Positive & & & & & & \\
\hline $2007 \mathrm{e}$ & Philippines & Positive & Positive & & & & Negative & Negative \\
\hline
\end{tabular}

Source: See first column.

An increase in employment was a common impact among all the studies. This implies that employment generation is a likely result of trade liberalisation in export-oriented industries. Aside from an increase in employment (positive), the common finding across all countries and industries was poor work conditions (negative). The first indicator of poor work conditions is low wages that were found in Peru, Guatemala and Nicaragua. While there were wage increases in Cambodia, if inflation is taken into consideration, Solidar (2007c) expresses that it was still not enough when compared to the rising standard of living. This means that the wage increases have not actually improved the conditions of workers. Thus, an increase in wages on its own is not an accurate indicator of decent work. Rather, inflation or 
the cost of living shall be taken into consideration when looking at the adequacy of wages.

The second indicator of poor work conditions found by the study is the lengthening of work hours in Cambodia and Peru (Solidar, 2007c \& 2007d). It can be noted that despite the prolonged work hours in Peru, jobs were still less secure (third indicator of poor work condition) because workers were not given formal contracts. Some of the workers were not even listed on the company roll (Solidar 2007d). Similarly, job insecurity was likewise found in Guatemala and Nicaragua where the employer preferred casual workers (Solidar, 2007b). The work tenure was uncertain as it has become dependent upon product demand. Employers took full control of the terms of employment and workers have limited voice. While the case studies indicate that the law grants workers freedom of association, union membership is discouraged at the plant level due to discrimination against union members (the fourth indicator of poor work condition found). The discrimination ranged from lowering work hours to termination of work (Solidar, 2007b, 2007c, 2007d). This resulted in low union membership. Hence, even if collective bargaining exists, this indicator of decent work does not necessarily lead to better work conditions for all workers if union density is low. Thus, the existence of collective bargaining as an indicator of decent work must be interpreted alongside union density.

In addition, the freedom of association as an indicator of trade liberalisation is also rendered useless when workers are not aware of how to exercise their communal rights. In a case study in Peru (Solidar, 2007d), although workers established support groups, these groups are were limbo as to what to do to improve or strengthen their bargaining position. In addition, Solidar argued that the vulnerability of workers in Peru was aggravated by the fact that $14 \%$ of women workers were found to be illiterate. Solidar implied that the literacy of workers plays an important part in improving their work conditions. Thus, for decent work to operate, the workers' rights must be able to combine knowledge of those rights and the availability and accessibility to mechanisms that redress any violations. 
The fifth and sixth indicators of poor work conditions found in the research are issues of health and safety in the case of Cambodia (Solidar, 2007c) and the Philippines (Solidar, 2007e). In the case study on Cambodia, workers were prone to kidney infections due to restrictions on the use of the toilet. On the other hand, within call centres in the Philippines, although wages were higher than in other industries, workers developed heart ailments and other illnesses due to erratic eating and sleeping patterns. A high level of emotional stress was noted due to verbal abuses from clients and the rigidity and high demands of work and performance. Furthermore, the safety issues relating to accidents with machines (Cambodia) and going home late at night (Cambodia and Philippines) were also discovered.

The increase in employment with a corresponding decline in work conditions in the Solidar case studies indicates a trade-off between employment demand on one hand and wages, work hours, job security, employee voice and health and safety on the other. This suggests a need for research on decent work to look into possible trade-offs that may exist between the areas of decent work.

\subsubsection{Numerical Flexibility}

Increased international competition and the uncertainty of product demand brought about by trade liberalisation compel employers to improve their ability to adapt to market changes in order to stay in business. This capacity to adapt is what is referred to as labour flexibility (Roca-Puig, Beltrán-Martín, Bou-Llusar \& EscrigTena, 2008). Several researchers have broadly categorised labour flexibility into 1) internal or functional flexibility and external or numerical flexibility (Atkinson, 1984, Kalleberg, 2001; Mcllory, Marginson \& Regalia, 2004). Internal flexibility and functional flexibility is closely related in the sense that functional flexibility refers to the ability of workers to take or move on to different tasks while internal flexibility refers to the firm's capacity to facilitate functional flexibility (Looise, van Riemsdijk \& Lange, 1998; Michie \& Sheehan, 2001). Internal flexibility is usually facilitated by hiring highly qualified employees or through the firm's continuous training programmes (Roca-Puig et al., 2008). External or numerical flexibility on the other 
hand refers to the ability of the company to add or reduce the workforce to suit the changing business environment (Matusik \& Hill, 1988). This can be done by subcontracting and employing contractual ${ }^{5}$ or temporary workers (Roca-Puig et al., 2008).

Empirical research shows that trade liberalisation has caused employers to resort to numerical flexibility. For instance, Bhalotra (2002) reports that although there were increases in wages, there was a growing change from self-employment to casualisation from the 1970 s to the 1990 s (the period where most liberal trade reforms were introduced in India). Again, this reinforces the argument that an increase in wages alone does not necessarily mean that work becomes acceptable or decent. Workers' wages may be higher but as casual workers, it means that their jobs become less secure. There may be again a 'trade off' between numerical flexibility, wage increase and job security.

Similarly, a separate research on the clothing, garment and textile sectors in different countries also demonstrate that free trade (in Tunisia, Morroco and Algeria) and the end of the Multi-fibre Agreement (in Indonesia) caused a shift towards informalisation (no formal contracts with the firm) and self-employment (Hunt et al., 2007; Robertson, Sitalaksmi, Ismalina \& Fitrady, 2009). Employment became irregular as it turned out to be dependent on product demand (Hunt et al., 2007). Because work is contingent upon the duration of the orders, employers hire only contractual workers (Robertson, Sitalaksmi, Ismalina \& Fitrady, 2009), preferring those who are younger and better educated (Hunt et al., 2007). Furthermore, because of the costly termination of workers in Indonesia, some employers increased the working hours (Robertson, Sitalaksmi, Ismalina \& Fitrady, 2009). Since workers had to compete for a limited number of jobs, many have accepted employment at a lower wage (Hunt et al., 2007).

\footnotetext{
${ }^{5}$ Where the contract of employment is only within a defined period of time. Contractual workers are considered temporary workers.
} 
The employment of contractualisation and informalisation, aside from manpower flexibility, is a cost reduction measure. Employers are not mandated to provide medical benefits or company pension contributions to contractual or causal workers in contrast with permanent workers (Hunt et al., 2007).

The body of literature implies that employers are introducing different employment strategies in order to cope with growing international competition. Thus, in examining the impact of trade liberalisation on decent work, it is imperative to give attention to the employers' employment strategies as these may influence or affect the decency of work. Furthermore, it shows that trade liberalisation leads to downward pressure on working conditions.

\subsection{Effect of Trade Liberalisation in the Philippines}

The impact of trade liberalisation on decent work in the Philippines has also been examined, albeit in a limited extent. Trade liberalisation has been mostly measured by export-import figures and reduction in tariffs while work conditions on the other hand were examined in terms of increase or decrease of employment, real wages and work structure.

\subsubsection{Employment and Wages}

Research by Orbeta (2002) suggests that trade liberalisation, based on exportimport flows in relation to employment creation, resulted in an increased shift to export-orientation. As a result, it increased aggregate employment in the Philippines. On the other hand, the effect of an increase in imports has no significant effect on labour demand. To explain the insignificant effect of imports on employment, Ranney and Naiman (1997) argue that the theory of job generation as an effect of trade liberalisation using import-export figures does not apply to the Philippines where imports exceed exports by more than two to one. Ranny and Naiman are therefore implying that export-import figures may not be a good indicator of job generation in the Philippines. Thus, in Philippine research in relation 
to job generation, trade liberalisation should be operationalised using additional indicators other than the import-export data.

Another attempt to determine the impact of trade liberalisation in the Philippines is the research of Serrano (1997). Serrano maintains that trade liberalisation in the Philippines has caused unemployment and a reduction in real wages. The author emphasises the role of labour unions as important in attaining favourable working conditions for workers especially in negotiating for an increase in wages and recommends a concerted effort by labour unions towards this end. Serrano is therefore implying that the union's structure and bargaining power is a variable factor in social upgrading. Thus, research on decent work should also take into account the influence of the union's bargaining power and structure on the decency of work.

Likewise, the Structural Adjustment Participatory Review International Network (SAPRIN) (n.d.) had an occasion to explore the impact of trade liberalisation in the Philippines involving the garment, cement and sugar industries. These industries are protected by tariffs because their production costs are higher than other international competitors. Just like the other researchers, the author concludes that liberalised trade did not have any significant impact on job creation in the Philippines. For the cement industry, as many as 100 companies have closed businesses. This suggests that so far, the very few existing Philippine empirical research studies on trade liberalisation unanimously conclude that it did not have a positive impact on job creation in the Philippines particularly on protected industries.

\subsubsection{Labour Flexibility and a Shift to Skilled Work}

Research also found that trade liberalisation resulted in growing labour flexibility in terms of: (1) preference for casual and temporary workers in lieu of permanent workers; (2) subcontracting other production processes; and, (3) paying workers by piece rates (SAPRIN, n.d.). The SAPRIN study found in the garment sector, a decrease in overall employment and a shift towards subcontracting. For the sugar 
industry, the study reported that the grant of importation has reduced the income of sugar farm workers. The research however did not provide any findings as to sugar mill workers as it interviewed only one sugar mill worker out of its 142 respondents. This implies that the impact of trade liberalisation on mill workers remains unclear. As such, there is a gap in this area of research.

Research looking at the effect of trade liberalisation on workers' skills was examined using aggregate industry-level data and reported a decline in low-skilled workers with a simultaneous increase in skilled and managerial workers (Lim \& Bautista, 2002). Lim and Bautista cannot determine with certainty the reason for the change, explaining that data at the national level is usually scarce and limited and is usually available only at each establishment. They however theorise that the changes in the percentage of skilled work in the Philippines can be more seen as a shift of employment from unskilled to skilled across sectors rather than a change in the composition of skilled or unskilled workers. This stresses the limitation of using the national and industry-level data compared to information sourced from the workers. Thus, in order to understand the dynamics of the changes in skills, similar research must be conducted at the workplace-level.

The impact of trade liberalisation on decent work had also been examined in relation to the changes in human resource management (HRM) practices in the Philippines. This will be discussed in the next section.

\subsection{Changes in HRM Practices in the Philippines}

HRM practices are influenced by the government's (economic) development strategy and the degree of exposure to globalisation (Frenkel \& Kuruvilla, 2002). In the Philippines, Amante (1997) reports that the HRM practices were traditionally characterised by work assignments that are structured, specific, and regularly supervised. Wages are generally negotiated through collective bargaining agreements with no link to productivity (Amante, 1997). However, the government 
has shifted from an import substitution industrialisation (ISI) to an export-oriented industrialisation (EOI) strategy (Frenkel \& Kuruvilla, 2002). Thus, trade barriers such as quantitative importing restrictions and tariffs that used to protect domestic industries were slowly reduced or eliminated. As a result, domestic firms became more vulnerable to international competition. In response, changes to HRM practices were introduced by companies to make their firm more competitive (Skene, 2003).

The changes in HRM practices demonstrate a shift towards practices used by EOI sectors. In summarising the change in HRM practices in the Philippines, Skene (2003) has divided the practices into those employed by the import substitution industrialisation (ISI) sector and the export-oriented industrialisation (EOI) sector. These practices were generally based on a case study of seven of the largest corporations in the Philippines conducted by Amante (1997). Hence, Skene (2003) considers these as the best practices in the Philippines. Table 3 presents a summary of the changes in HRM practices. 
Table 3. Changes in HRM Practices In the Philippines

\begin{tabular}{|c|c|c|}
\hline & Pre-1997 Practices & Current Practices \\
\hline \multirow{6}{*}{$\begin{array}{l}\text { ISI } \\
\text { sector }\end{array}$} & Fairly rigid workplace structures & Fairly rigid workplace structures \\
\hline & Adherence to work rules & Adherence to work rules \\
\hline & $\begin{array}{l}\text { Rigid compensation systems with } \\
\text { no linkages to skill acquisition or } \\
\text { merit }\end{array}$ & Some efforts to link pay to merit \\
\hline & $\begin{array}{l}\text { Virtually all workers employed on } \\
\text { a regular basis }\end{array}$ & $\begin{array}{l}\text { Efforts towards greater numerical } \\
\text { flexibility through layoffs and } \\
\text { Contracting }\end{array}$ \\
\hline & $\begin{array}{l}\text { Little emphasis on training beyond } \\
\text { initial rectruitment stage }\end{array}$ & $\begin{array}{l}\text { Increasing emphasis on training and } \\
\text { skill upgrading }\end{array}$ \\
\hline & Passive attitude towards flexibility. & $\begin{array}{l}\text { Efforts towards functional flexibility } \\
\text { in some firms }\end{array}$ \\
\hline \multirow[t]{4}{*}{$\begin{array}{l}\text { EOI } \\
\text { sector }\end{array}$} & $\begin{array}{l}\text { Fairly rigid workplace structures in } \\
\text { most firms }\end{array}$ & $\begin{array}{l}\text { Fairly rigid workplace structures in } \\
\text { most firms }\end{array}$ \\
\hline & $\begin{array}{l}\text { Strong focus on numerical flexibility } \\
\text { through layoffs and contracting }\end{array}$ & $\begin{array}{l}\text { Increasing concern over cost } \\
\text { Containment } \\
\text { Widespread use of practices to } \\
\text { enhance numerical flexibility } \\
\text { including contracting and layoffs }\end{array}$ \\
\hline & $\begin{array}{l}\text { Efforts to de-link pay from skill } \\
\text { acquisition }\end{array}$ & $\begin{array}{l}\text { Efforts to de-link pay from skill } \\
\text { Acquisition }\end{array}$ \\
\hline & $\begin{array}{l}\text { Some efforts towards functional } \\
\text { flexibility in foreign owned } \\
\text { electronics firms }\end{array}$ & $\begin{array}{l}\text { Some efforts towards functional } \\
\text { flexibility in foreign owned } \\
\text { electronics firms }\end{array}$ \\
\hline
\end{tabular}

Source: Skene (2003).

Skene (2003) reported that traditionally (before 1997), in the ISI sector, compensation systems were fixed with no reference to skill or performance. Companies employed regular (permanent) workers. Training was basically on the job and limited to the skills required for the workers to perform their assigned tasks. For instance, machine operators were trained to operate machines, leaving the repair of machinery to other workers. Hence, functional flexibility was not practiced. Recent trends however suggest that current practices partly reflect some link between compensation and performance. Likewise, there is a growing trend of companies employing numerical flexibility through the reduction of the regular workers and replacing them with workers from independent contractors. There is also a conscious effort of training workers to upgrade their skills. For instance, machine operators are now trained to repair the machines they operate. This was to promote functional flexibility (Skene, 2003). 
In the EOI sector, HRM practices have minimal changes. Traditional employment strategies have already focused on numerical flexibility through lay-offs and contracting. This practice is still largely used in current years. Some companies have also practiced functional flexibility particularly in the electronics industry under foreign ownership. Unlike the ISI sector, there is an effort in the EOI sector to reduce the link between workers' skills and compensation both traditionally and currently. In summary, recent HRM practices have shown a growing pattern of cost reduction.

\subsection{Summary and Conclusion}

The summary of the literature relating to trade liberalisation in general and the social upgrading of workers signifies that the impact of trade liberalisation on the four aspects of decent work (job generation and quality of employment, rights at work, social protection and social dialogue), is influenced by several factors. A theoretical framework (Figure 3 ) is created to illustrate a summary of these factors. 
Figure 3. Theoretical Framework

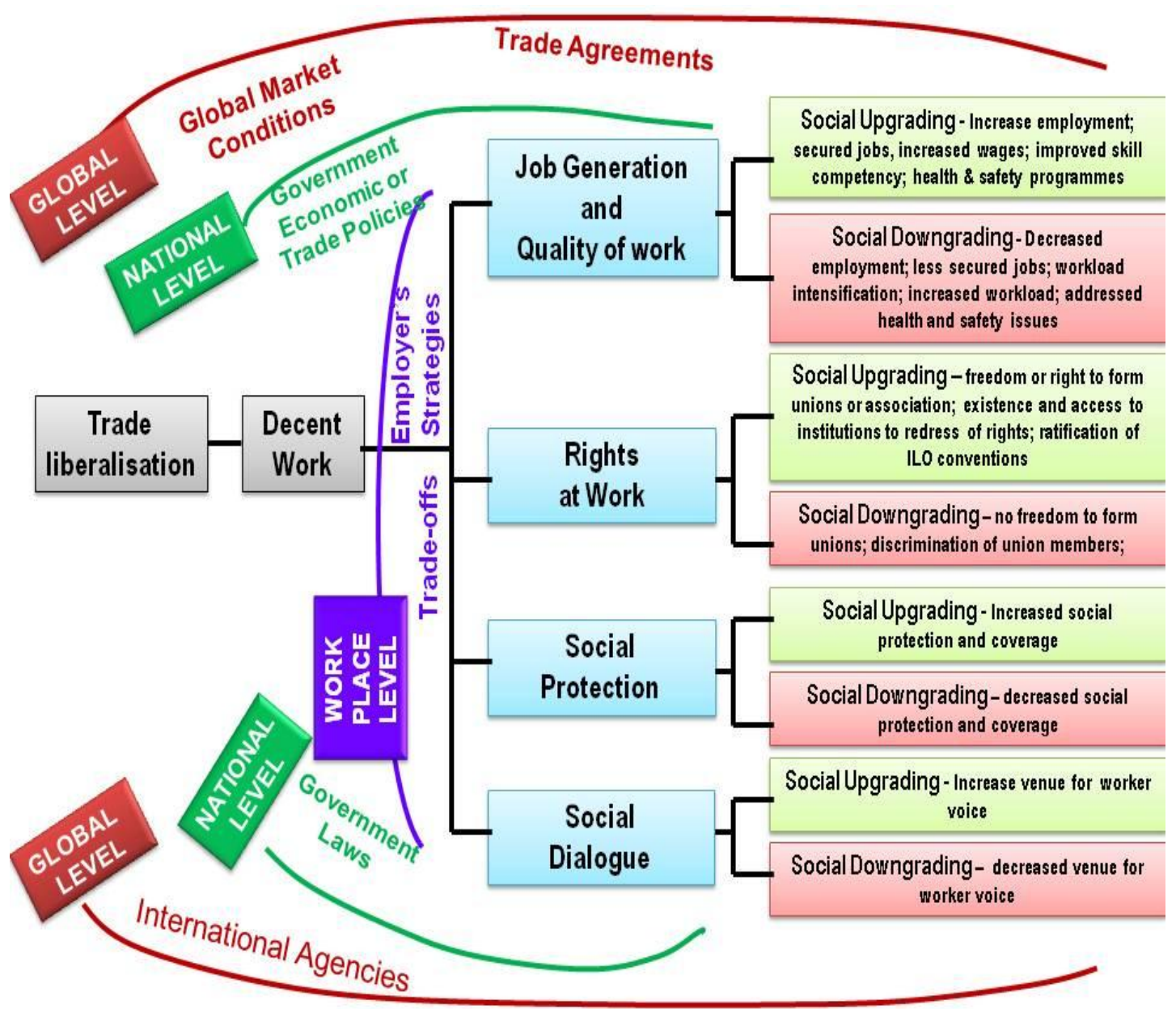

The literature demonstrates that at the global level, there are three identified factors that facilitate trade liberalisation. First is the global market condition which relates to the intensity of international competition for a particular industry. This is determined by the export and import figures. The second factor is trade agreements. This is in the form of termination of preferential agreements, tariff reductions or removal of import restrictions whether fully or partially. The third factor refers to the influence of international agencies, such as the IMF whose priority is economic development through trade liberalisation and the ILO whose main thrust is decent work for workers by promoting labour laws through ILO conventions. At the national level, the government's economic or trade policies influence the degree of exposure of industries to international trade. This creates subsequent effects on decent work. In addition, the literature stresses that government laws must be scrutinised to determine whether laws enacted in favour 
of workers are actually implemented. At the workplace level, the employers' employment strategies such as economic upgrading, and resorting to numerical flexibility to address competition have been shown to greatly affect employment demand and work conditions. Furthermore, buyer requirements from the global to the workplace level can also affect decent work.

The impact on decent work may be categorised as social upgrading or downgrading. Indicators of social upgrading include increased employment, secure job, increased wages, increased worker voice and existence of company programmes addressing health and safety issues. Social downgrading on the other hand is indicated by decreased employment, less secure job, decreased wages, work intensification, union membership discrimination, suppression of worker voice and persistent health and safety issues.

The findings in the literature on the impact of trade liberalisation among developing countries include low wages, prolonged work hours, lesser job security, union membership discrimination and health and safety issues. These were usually found in protected industries where there was a significant increase in imports, a reduction of preferential trade agreements or tariffs. On the other hand, for export oriented industries, increases in exports led to increases employment. For wages, although increases were reported, the inflation rates have also increased making some the wage increases insignificant. In addition, the literature has also reported trade-offs from different indicators of decent work which highlights the need to examine the relationships of these indicators.

The Philippine literature on trade liberalisation is also consistent with the results of research in developing countries. Generally, reduction of the workforce and decrease in wages were also reported in industries that were not cost-competitive internationally. Furthermore, trade liberalisation has resulted in changes in the HRM practices in the Philippines. The changes specifically in ISI include the employment of contractual or casual workers to create greater numerical flexibility, 
linking pay to performance and intensified training for purposes of functional flexibility as a cost reduction measure.

In conclusion, the literature suggests that the exposure to intense competition due to liberal trade policies has led firms to aim for productivity and focus on cost reduction. Hence, workers of protected industries or those whose cost of production could not compete with more cost-efficient competitors will likely experience more social downgrading than social upgrading. The only factor found in the literature to have consistently upgraded work conditions was buyerrequirement. Labour laws on the other hand can result in social upgrading only when it is successfully implemented.

The next chapter will present the research question and justify the research strategies that were used to arrive at a justifiable conclusion. 


\section{Chapter Three}

\section{Methodology}

\subsection{Introduction}

To provide transparency in this research process, this chapter outlines the methodology used in this research. It starts by presenting the research aim, the research question and the sub-questions. It states that this is an exploratory research and presents the rationale for using the qualitative approach and the single case study method. It also reveals the measures taken by the researcher in consideration for research ethics.

\subsection{The Research Aim}

As stated earlier, this study explored the impact of trade liberalisation on the social upgrading of the Philippine sugar mill workers by examining decent work at the workplace level. To attain the research aim, this study posed the research question...

How has trade liberalisation impacted on decent work among the sugar mill workers in the Philippines?

To guide the researcher in answering the research questions, the following subquestions were presented:

1. What are the effects of trade liberalisation on the level of employment and the quality of employment at the sugar mill?

2. What are the effects of trade liberalisation on the freedom of association of mill workers and their right to form labour unions?

3. What impact does trade liberalisation have on the employment protection of sugar mill workers? 
4. What impact does trade liberalisation have on the representation and negotiations between sugar mill workers, their employers and the government?

\subsection{The Research Approach}

This research is exploratory and deductive in nature. It does not seek to test a theory but instead provide a preliminary investigation. The rationale for using such an approach is that the exploratory nature of the research will serve the purpose of expanding the limited literature on the impact of trade liberalisation on decent work among sugar mill workers in the Philippines. The next sub-sections will further outline the research approach employed in this study.

\subsubsection{Taking the Qualitative Approach}

One important aspect of good research is the use of an appropriate research approach. According to $O^{\prime}$ Leary (2010), there are two basic approaches to a research project depending on the mode of analysis one uses. These are the quantitative and the qualitative approaches. $O^{\prime}$ Leary argued that a quantitative approach is typically used to find a 'single truth' derived from statistical data and analysis. This, according to O'Leary, involves a larger number of participants. However the information derived is less detailed. For instance, quantitative research on stress among postgraduate students may identify the factors that cause stress but not on how they cope with stress. On the other hand, the 'how' aspect of a research question is usually answered using the qualitative approach which allows for variety and depth of response. O' Leary (2010) pointed out that studies using this approach are usually conducted with a smaller number of the population to obtain deeper information. Researchers choose either the qualitative or quantitative approach or a combination thereof depending on which approach is suited to answer their research question (O' Leary, 2010). 
In pursuing a qualitative approach for this research, several matters were considered. First was the impact of trade liberalisation on decent work based on the literature reviewed. These were found to be varied and complex. Tensions were found to exist between different areas of decent work. Generalising the impact into one single truth through quantitative analysis would disregard other relevant data given the infrequency in responses. Furthermore, the effects on decent work may be attributed to or influenced by many factors. Hence, a detailed description of the circumstances would allow the researcher to have a deeper understanding of the variety and complexity of results rather than restricting it to specific quantitative variables. Furthermore, the use of a qualitative approach for this kind of research is supported by Denscombe (2007) who maintained that the rich data in qualitative research allows the researcher to determine linkages of information between different variables.

\subsubsection{Using the Single Case Study Method}

The qualitative approach in this research was performed in a single case study. A case study is a method of investigation through detailed explanation and analysis of a particular occurrence in a real life situation (Brannick, 1987). Yin (2003) posited that the complex nature of a phenomenon may be best examined through a case study because of the thoroughness of its approach. Case studies facilitate understanding of the cause and effect of changes in events or people over time (Berg, 2005). Considering that this research examines a phenomenon (impact of trade liberalisation) over a period of time and the researcher wants to understand how the findings of existing research apply at the sugar mill in the Philippines, the case study method is considered appropriate for this research.

When using the case study method, researchers are faced with deciding between utilising single or multiple cases (Yin, 2003). The argument against using a single case is its limitation to make conclusive generalisation because it has not been tested in an adequate number of cases. However, Yin (1989) argued that provided the study meets the requirements of qualitative method namely, providing a sufficient context, understanding and transparency of the process, a single case can 
define the conditions to allow it to be replicated in another case. Furthermore, the use of a single case study is appropriate when the aim of the researcher is for exploration (Patton, 2002) and initial determination and upon which a multiple case study may be built on (Joia, 2004). For exploration purposes, the single case study method facilitates a more flexible examination of the subject in contrast with larger cases which because of the many cases, usually has predefined topics (Townend, \& Smith, 2007). Since this study is exploratory in nature as upon review, there has been no case study conducted on the impact of trade liberalisation on the sugar mill workers of the Philippines so far, and considering the limited timeframe allowed for this thesis, under these circumstances, the use of a single case study was appropriate.

The next section outlines how this research is consistent with Yin's (1989) suggestion of providing a sufficient context, understanding and transparency in this research.

\subsection{Sources of Data}

Although the focus of this research is at the workplace level, data from the global and national levels were also gathered. This was to provide a sufficient context and a product of the reflection in the previous chapter which emphasised the importance of different sources of data.

\subsubsection{Secondary Sources}

Information from secondary sources was collected prior to conducting interviews in order to provide a background of the sugar industry, both at the global and the national level. The secondary data included among others, sugar industry policies and reports, labour statistics, legislation, and historical data on sugar trading, production and export. The data were taken from the websites of the US Department of Agriculture and various Philippine government agencies such as the Department of Labour, the Sugar Regulatory Administration and the Department of 
Tourism. Information from industry-based institutions like the Philippine Sugar Millers' Association and the Sugar Industry Foundation, Inc. were likewise gathered.

\subsubsection{Primary Sources}

To facilitate the validity of the results and the earlier requirement for an accurate understanding of the data, the main source of data were taken from face-to-face individual interviews with representatives from different sectors. At the national level, research participants were from the sugar millers, the sugar planters, labour unions and the government sectors. At the workplace level, although the bulk of the research participants were representative of the workers (referring to rank and file workers ${ }^{6}$ ), key officials (supervisors and managers) were also interviewed to represent the employer. This approach was a reflection of the theory that case studies often use triangulation or multi-method to ensure the validity of its results (Tellis, 1997). Thus, this research used what Denzin (1984) refered to as 'data source triangulation' which is utilising different sources of information to facilitate a more accurate interpretation of the environment surrounding a given phenomenon (Brannick, 1987).

The use of these mixed sources in data gathering provided the researcher with thorough information to describe the context of the sugar industry which is presented in Chapter Four and the changes at the workplace level as presented in Chapter Five.

\subsection{Constructing the Research Instrument}

To determine the impact of trade liberalisation on decent work among Philippine sugar mill workers, there is a need to operationalise the key terms: 'trade liberalisation' and 'decent work'. Following on from a review of both the literature

\footnotetext{
${ }^{6}$ Rank and file workers refer to those workers occupying the positions below assistant supervisors. Hence, their work does not include supervision of personnel. Rank and file tasks includes repair and maintenance of equipment, operating machineries, sugar bag checkers, 'scalers' and other clerical tasks.
} 
and the empirical research it was found that trade liberalisation can be seen through a reduction of tariffs and preferential agreements and an increase or decrease in exports. Thus, the research participants at the national level were asked how these indicators affected the sugar industry, employers' strategies and government labour laws.

Decent work was divided into the four aspects as reported in the literature. As suggested by the previous chapter, the first aspect which is job employment and the quality of employment was explored by looking at the effect of the indicators of trade liberalisation on employment demand, wages, work hours, workload, skills and training and health and safety issues. The second aspect, rights at work, was explored by looking at the freedom of association and the right to form unions. The third aspect, social protection, was explored by looking at the existence of social benefits and its coverage. Lastly, the fourth aspect, social dialogue, was explored by looking at the existence of collective bargaining agreements and other venues of dialogue at different levels of negotiation.

The interview questions were semi-structured to focus responses on relevant information. At the same time, it provided an opportunity for the interviewees to clarify or qualify their responses.

\subsection{Research piloting}

Pilot interviews were held for each set of questionnaires to test the clarity of the questions. Several terms (e.g. social upgrading, work conditions, etc.) were rephrased in the questionnaire or further explained to interviewees after it was determined during the pilot interview that their definitions were vague. Copies of the final interview schedules are attached as Appendices B, C, D, E and F.

The pilot interview also revealed that interviews with the national level representatives as well as the managers and supervisors could be conducted in 
English. Thus, only the interviews with the workers were conducted in Hiligaynon, the native dialect (spoken by the researcher). This was done in order to facilitate a relaxed atmosphere and free flowing conversation. The actual interviews were conducted in the months of August and October 2011. After initial coding and analysis, follow-up questions were emailed to concerned respondents and their additional responses formed part of the findings.

\subsection{Identifying and Negotiating Access to Research Site and Respondents}

For the workplace level participants, the initial step was the selection of the sugar mill for the case study. The next step was how the participants will be recruited and selected. These are the topics discussed in the following sub-sections.

\subsubsection{Selection of Study Site}

Negros Occidental had been identified as the most appropriate site for the case study for two reasons. First, this region produces half of the country's sugar production and is home to 13 out of 30 sugar mills scattered all over the Philippine islands (Sugar Regulatory Administration, 2010). Second, several research studies regarding the sugar industry and its workers have considered the Negros Occidental region as an appropriate research site (Aguilar, 1984; Ledesma, 2005; LopezGonzaga, 1983; Nagano, 1988).

Within Negros Occidental, the selection of the mill was influenced by the criteria that the mill must have initiated major changes to be internationally competitive. Hence, the identification of the sugar mill that suits these criteria was based upon the recommendations from national level representatives of different sectors 
(employers, workers and government) lealding to the identification of the sugar mill - Azucarero. $^{7}$

\subsubsection{Recruitment}

Broadhead and Rist (1976) argued that in conducting research on bureaucratic organisations, a researcher's access to data and respondents may be done by acquiring the consent of the 'gatekeeper'. Research methodology literature points out that a gatekeeper may limit or facilitate access to the research site and the participants (Burgess, 1991; Broadhead \& Rist, 1976; Wanat, 2008). In keeping with the patriarchal Philippine culture where consent is requested from the person occupying the highest position as the 'father of the family', an invitation (a copy of the letter to the Mill is attached as Appendix G) was sent to the company president of a sugar mill located in Negros Occidental to participate in the research. After a meeting with the researcher, the company president granted permission to interview the mill's officials and workers at the mill site.

\subsubsection{Sampling Strategy}

According to Arber (2008), probability and purposive (or non-probability) sampling are the main categories of sampling strategies. In probability sampling, every individual in the population has the same chance of being selected. Arber explained that this sampling strategy is used when a researcher wants to get a common response from a population and derive inferences from the findings with a definite margin of error. Purposive sampling on the other hand, is used when the purpose is to formulate a theory, explore social interactions, or when selecting a small sample in the initial unit (e.g. three local government units within a state). In this case, lesser importance is placed on representatives of a population (Arber, 2008).

Arber (2008) further stated that among the examples of the purposive sampling method is judgmental sampling where samples are judged based on the knowledge

\footnotetext{
${ }^{7}$ A fictitious name was used to hide the identity of the sugar mill in compliance with ethical requirements. Considering the Spanish influence over Filipinos, the Spanish word for sugar mill was used in place of the real name of the mill.
} 
they possess which is relevant to the subject under investigation. Many researchers agree that participants in research may be chosen when they are in a better position to provide more information relative to the research issue (Arber, 2008; O' Leary, 2010; Shank \& Brown, 2007). Table 4 outlines the sample frame and the criteria used to identify the research sample.

Table 4. Sampling Frame

\begin{tabular}{|c|c|c|c|}
\hline \multicolumn{3}{|c|}{ NATIONAL-LEVEL RESPONDENTS (identified through purposive sampling) } \\
\hline CRITERIA & WORKERS & EMPLOYERS & GOVERNMENT \\
\hline Key official in ... & $\begin{array}{c}\text { A national level } \\
\text { Labour Federation }\end{array}$ & $\begin{array}{c}\text { The Philippine Sugar } \\
\text { Millers' Association } \\
\text { \& CONFED }\end{array}$ & $\begin{array}{c}\text { The Sugar } \\
\text { Regulatory } \\
\text { Administration }\end{array}$ \\
\hline NUMBER OF RESPONDENTS & 1 & 2 & 2 \\
\hline $\begin{array}{c}\text { KEY INFORMANT: Known in the industry to possess } \\
\text { historical knowledge about the sugar industry } \\
\text { and its workers }\end{array}$ & $\begin{array}{c}\text { Number of } \\
\text { Respondent }\end{array}$ & 1 \\
\hline \multicolumn{2}{|c|}{ TOTAL NUMBER OF RESPONDENTS } & 6 \\
\hline
\end{tabular}

\begin{tabular}{|c|c|c|}
\hline \multicolumn{3}{|c|}{ PLANT-LEVEL RESPONDENTS } \\
\hline \multicolumn{3}{|c|}{ Workers' Representatives (identified through random sampling) } \\
\hline \multicolumn{2}{|c|}{ CRITERIA } & $\begin{array}{l}\text { TOTAL } \\
\text { RESPONDENTS }\end{array}$ \\
\hline $\begin{array}{l}\text { 1. A permanent employee } \\
\text { 2. Have been working in } \\
\text { the sugar mill for at } \\
\text { least ten years }\end{array}$ & $\begin{array}{l}\text { at least } 10 \% \text { of the } \\
\text { permanent } \\
\text { workforce } \\
\text { (Total permanent } \\
\text { workers }=278 \text { ) } \\
\end{array}$ & 30 \\
\hline \multicolumn{3}{|c|}{ Employer's Representatives (identified through purposive sampling) } \\
\hline & Position/Designation & TOTAL RESPONDENTS \\
\hline \multirow{2}{*}{$\begin{array}{l}\text { Have been working in the } \\
\text { sugar mill for at least ten } \\
\text { years }\end{array}$} & Senior Manager & 1 \\
\hline & Line Managers & 2 \\
\hline \multicolumn{2}{|c|}{ TOTAL NUMBER OF RESPONDENTS } & 33 \\
\hline
\end{tabular}

\subsubsection{Purposive sampling}

O' Leary (2010) explained that in exploratory research, it is appropriate to select key informants who have a deeper understanding of a particular situation rather than resorting to representative samples. Consistent with this reasoning, at the national level, six participants were identified based on their knowledge of the industry and their position in the sector they represent. The respondents were officials belonging to the top level management of their affiliated organisations. The 
respondent who was chosen to represent the workers is an official from a national labour union. For the employers' representative, the sugar industry has two types of employer: the miller and the sugar planter. Hence each type of employer was represented. The miller's representative was identified from the Philippine Millers' Association, a national organisation representing a large majority of the millers. With respect to the sugar planters/farmers, the representative is an official of the Confederation of Sugar Producers' Association (CONFED) which is the largest sugar planter federation in the Philippines. The government sector is represented by a senior management official and a line manager. To gather relevant historical information, a key informant who, based on the interviews from the representatives of the national level, was known to possess historical knowledge about the sugar industry and its workers, was also included as a respondent.

Likewise, purposive sampling was also used in determining the representatives of the employer at the workplace level. At the workplace level, in order to gather information as to the rationale for the changes in employment strategies employed by the sugar mill, a senior management official was interviewed. Furthermore, a plant manager and the human resource manager were also interviewed in order to gather data on human resource programmes and changes to work structure as well as the changes in technology and tasks at the sugar factory.

\subsubsection{Random sampling}

The chosen sugar mill has 350 employees, 278 of which are rank and file workers. In terms of contractual arrangements, 24 contractual workers supplement the workforce. Since these contractual workers were employees of an independent contractor, they were not made participants in this study. In order to get a variety of responses as to the changes of work conditions among employees, random sampling was employed. In doing so, the sugar mill was requested for a list of all its employees who have worked for the mill for at least ten years. The length of service requirement was set because participants were asked to describe changes in their

working conditions over a period of time. Random sampling using the lottery method was used to draw 30 rank and file workers. However, it was ensured that 
respondents came from different departments, divisions or sections to facilitate a variety of responses (stratified random sampling). This included the different sections of the factory and the administrative divisions. Additionally, four supervisors/heads representing different departments and sections were also purposively selected to supplement and verify the information provided by the workers. Table 5 illustrates that respondents were drawn from across the workforce population.

Table 5. The Mill's Workforce Composition

\begin{tabular}{|l|r|r|}
\hline & Population & \multicolumn{1}{|c|}{ Sample } \\
\hline Senior \& Line Managers & 5 & 3 \\
\hline Department Heads & 8 & 0 \\
\hline Supervisors & 39 & 4 \\
\hline Assistant Supervisors & 25 & 0 \\
\hline Rank and File Workers & 278 & 30 \\
\hline TOTAL Permanent Workers & 350 & 37 \\
\hline Contractual Workers & 24 & 0 \\
\hline Total & 374 & 37 \\
\hline
\end{tabular}

Table 6 presents the respondent workers' profile categorised according to their years of service in the mill and their educational background. The figure shows that six of the respondents have been working at the sugar mill for 30 years or more while almost half (16) of the respondents have been employed by the sugar mill for 20 to 29 years. The remaining eight have been in the company for ten to 19 years. Being with the mill for ten years or more, respondents were able to recount changes to their work situation as far back as the 1980s. On the other hand, the educational background of the respondent workers ranged from those with secondary education to holding a degree. One of the respondents had a secondary education while ten have finished a technical or vocational diploma. Technical or vocational skills included carpentry, welding, automotive repair, electronics and the like. Thirteen respondents have reached tertiary level and six of them hold a 
bachelor's degree. This data is provided in relation to skills training in the analysis chapter.

Table 6. Profile of Participants

\begin{tabular}{|c|l|r|}
\hline \multirow{3}{*}{$\begin{array}{c}\text { Respondents' } \\
\text { Years in Service }\end{array}$} & 30 years and over & 6 \\
\cline { 2 - 3 } & 20 to 29 years & 16 \\
\cline { 2 - 3 } & 10 to 19 years & 8 \\
\cline { 2 - 3 } $\begin{array}{c}\text { Background } \\
\text { Educational }\end{array}$ & TOTAL & 30 \\
\cline { 2 - 3 } & Secondary education & 1 \\
\cline { 2 - 3 } & Tertiary Level (university) & 10 \\
\cline { 2 - 3 } & Bachelor's Degree & 30 \\
\cline { 2 - 3 } & TOTAL & 6 \\
\hline
\end{tabular}

\subsection{Analytical tools}

This research mainly uses thematic exploration as an analytical tool. Following the suggestion of Aronson (1994) and Spradley (1979) in conducting interviews and thematic analysis, the interviews were voice recorded and a summary transcript of the discussion was made every five minutes of each interview. The transcripts were then plotted into a summary and coding chart in Microsoft Excel format. Themes were identified following several readings and colour coding the summary and coding sheet was implemented. The common themes were then drawn and became the materials for the findings and presented in Chapters Four and Five.

\subsection{Ethical Considerations}

In consideration of ethical requirements, all participants, including the management of the selected sugar mill were provided with information on the research topic and how they will be affected by the project before consent was obtained. After which, a consent form was requested to be signed by the participants. Participants were also given opportunity to withdraw their 
participation or any piece of information they had provided that they felt was incriminating. Confidentiality was strictly enforced and the final write up is presented in aggregate form. Fictitious names were used when respondents were quoted. For some participants (particularly government officials), it was explained that it may be difficult to keep their identity anonymous. They were made aware that their participation was voluntary and they were given a period to withdraw their participation and the information they had provided. The raw data (recorded interview and transcript) was kept in a password protected file, is only accessible to the researcher and will be destroyed a year after the interview took place. A copy of the Information Sheets and Consent Forms are attached as Appendices $\mathrm{H}, \mathrm{I}, \mathrm{J}$ and K. This study sought and was granted approval by the Human Ethics Committee of Victoria University of Wellington.

Using the methodology outlined, the next two chapters present the findings from the data gathered. Chapter Four provides the sugar industry context while Chapter Five presents the data gathered at a workplace level. 


\section{Chapter Four}

\section{The Philippine Sugar Industry in Context}

\subsection{Introduction}

The purpose of this chapter is to provide a background of the Philippine sugar industry; keeping the view that the impact of trade liberalisation is context dependent. As such, the chapter starts by briefly describing the global set up of sugar and situating the Philippine sugar industry in the global context. It provides the historical background of the Philippine sugar industry in order to highlight the current challenges in the industry. Moreover, the chapter also emphasises the responses of the Philippine government to the changes in the international market. Furthermore, it illustrates the governance structure of the industry to show the relationships among its key actors. Lastly, the chapter outlines the current plan of the industry players to address future global competition.

\subsection{The History of the Philippine Sugar Industry}

Agriculture is one of the major industries in the Philippines. Among the agricultural crops, sugar is considered a high value crop for export. It contributes about Php70 Billion per year to the country's gross national product (Coscolluela, R. in Amarra, A. Personal Communication, May 17, 2011).

The latest data from the SRA (2010) reported that about 1.97 million metric tons of raw sugar was produced from 30 sugar mills in the crop year 2009-2010. Seven of these mills were located within Luzon, 19 from Visayas and four from Mindanao. For refined sugar, production was around 984,000 metric tons. ${ }^{8}$ Out of the 13 sugar refineries, four were from Luzon, seven were from Visayas and two from Mindanao.

\footnotetext{
${ }^{8}$ The equivalent of $19,684,065$ 50-kilo bags as reported in the SRA Sugar Bulletin No. 52-a, Week ending August 31, 2010.
} 
A map of the Philippines indicating the location of sugar mills has been attached as Appendix L.

The following subsections outline the history of the sugar industry and the interventions of government that favoured the industry.

\subsubsection{Phase I: The Development of the Sugar Industry (1500-1800)}

Before the Philippines was colonised by Spain, sugar production was already established in the country, albeit in small quantities using crude equipment (Billig, 1993). When it was colonised in $1521,{ }^{9}$ the influx of Spaniards coming to Manila ${ }^{10}$ resulted in the shortage of several commodities including sugar. Sugar came from Chinese traders and exports were prohibited. Meanwhile, sugarcane growing expanded to other provinces and by the 1770s, there was enough sugar for domestic needs. In 1755, the country started exporting sugar to other Asian countries. Sugar export continued to increase and between 1755-1779, the Philippines became the largest sugar exporter in Asia (SRA, 2012c).

The SRA (2012c) reported that in the Visayas region, sugarcane planting gained its momentum sometime in 1850 when British Vice-Consul Nicolas Loney pushed his company to finance sugarcane planting in Iloilo. Crop loans were introduced, sugarcane cuttings were imported, and modern machinery from England and Scotland were offered under easy installments. Loney made it possible to export his sugar from the Visayas to British colonies such as Australia and New Zealand which were feasible markets for raw sugar (commonly referred to as brown sugar). When world sugar prices continued to increasd in 1857, Loney promoted the expansion of sugarcane growing to the neighboring island, Negros. Since land was then cheaper in Negros, many wealthy families from Iloilo transferred to Negros and planted sugarcane in larger farms. Soon, the Visayas islands particularly Negros, ${ }^{11}$ exceeded

\footnotetext{
${ }^{9}$ Spanish colonisation lasted for more than 300 years.

${ }^{10}$ Manila is the capital of the Philippines and is located in the Luzon area.

${ }^{11}$ Negros until now still produces more than half of the country's total sugar production per SRA records.
} 
the sugar production of Manila and became the source of sugar exports to the US, England and Australia. At that time, Manila remained the source of sugar exports to Spain. However, the 1899-1901 war damaged many of the sugar plantations resulting in a significant drop in production and the industry had a slow recovery after the war (SRA, 2012c).

\subsubsection{Phase II: US Dependency (1900-1973)}

The SRA (2012c) records revealed how the Philippines became dependent on the U.S. market. The years between 1900-1973 showed that the sustainability of the Philippine sugar industry had mainly depended on the US TRQ. The growth of the Philippine sugar production started picking up again during the American regime (1898-1946) when it allowed the Philippines to export sugar to the US under preferential treatment. The SRA records (2012c) revealed that in 1902, the US allowed sugar imports from the Philippines with only $75 \%$ duties. This preferential treatment was amended in 1909 by the US Congress under the Payne-Adlrich Tariff Act which allowed $100 \%$ tariff free sugar imports from the Philippines of up to 300,000 tons. In 1913 , the quantitative limitation was lifted by the UnderwoodSimons Tariff Law, hence sugar from the Philippines was then freely exported to the US tariff free. This triggered an increase in sugar production by $500 \%$ from the crop year 1912-1913 (206,000 tons) to crop year 1933-1934 (1,565,405 tons). There were about 47 sugar mills during that time. However, the US later restricted its sugar programme, cutting imports in 1934. When the Philippines lost its major market, sugar production became less feasible and some sugar mills terminated operation. The Philippine legislature issued the Sugar Limitation Law of 1934. It restricted sugar production according to existing quota. Meanwhile, the Philippines continued to lobby for the increase of its sugar quota with the US. This resulted in the Philippines receiving a sugar quota under the amended US Sugar Act of 1960. Further increases were added in the 1965 US Sugar Act. From a basic quota of 70,000 short tons in 1962 , this was increased to $1,050,000$ short tons with further quota increases in whenever consumption increased in the US or there existed shortages in its domestic production. Once again, Philippine sugar production 
expanded. The 24 sugar mills in the crop year 1960-1961 increased to 37 mills, producing a record high production of 2.3 million short tons (SRA, 2012c).

\subsubsection{Phase III: Government Interventions (1974-1985)}

The industry again struggled during the period 1974-1985. Appendix L presents a historical account of the Philippine export to the US in comparison with its total raw sugar production between 1980-2010. It shows a general trend of declining sugar exports to the US. This led the Philippine government to intervene to sustain the profitability of sugar farming.

\subsubsection{Market structure}

The SRA (2012c) records revealed that in 1974, the Sugar Act expired leading to a drastic reduction in the preferential treatment of Philippine sugar. The drop in world sugar prices from 65 cents per pound in 1975 to six cents per pound in 1977 further aggravated the situation. With 42 sugar mills operating in the crop year 1977-1978 and having lost its major market, the Philippines was forced to compete in the international market. Faced with oversupply and deteriorating sugar stocks, sugar production dropped from 2,879,909 metric tons in the crop year 1975-1976 to 2,289,335 in the crop year 1978-1979 (Philippine Sugar Millers' Association (PSMA), 2011a).

\subsubsection{Government interventions}

To address the issues faced by the sugar industry, several agencies and institutions were created by the government. In 1977, President Ferdinand Marcos created the Philippine Sugar Commission (PHILSUCOM), a government agency mandated to oversee sugar production and set up protective policies. To shelter the sugar producers from the fluctuations of world sugar prices, PHILSUCOM entered into a '4-year-long term export contracts' involving $50 \%$ of the country's sugar production at a price lower than the prevailing prices at that time. This further led to the creation of the National Sugar Trading Corporation (NASUTRA) which became the country's single sugar buying and trading agency. NASUTRA handled the export of sugar and dictated the prices to be liquidated to the sugar farmers. Meanwhile, 
sugar prices in the world market continued to drop and while the long-term contract had shielded the sugar industry, many of the sugar farmers benefited less from the contract. This led to some sugar producers to demand free enterprise of sugar trading, allowing them to sell their sugar to buyers other than the NASTURA. This was granted under Presidential Decree No. 1905 in February 1984. However, its implementation was cut short because of the lobbying of the Philippine Sugar Association, the members of which were also sugar producers. The export of sugar was again given back to NASUTRA in June 1984. Further, to appease the sugar producers, in 1985, President Marcos ordered the re-organisation of the PHILSUCOM. But before its re-organisation was completed, a bloodless revolution ousted Marcos from the presidency. He was replaced by President Corazon Aquino (SRA, 2012c) and PHILSUCOM was abolished.

It was also within this period that a major labour legislation was enacted. The Labor Code of 1974 (Republic of the Philippines, 1974) codifies and strengthens existing labour laws. It prescribe labour standards such as the minimum wage, hours of work, service incentive leave, payment for overtime and holiday pay and mandates no diminution of existing benefits. The services of permanent or regular workers can not be terminated except for any of the grounds stated in Article 282-284 of the Labour Code (e.g. serious misconduct, gross habitual neglect of duties, commission of a crime against the employer, etc.). In cases where termination is allowed (e.g. due to installation of saving devices) the law requires payment of separation which is usually based on the length of service of the worker with the company. The law also mandates employers to provide workers with advance notice in case of termination. It requires employers or workers to present a 30-day notice in case of strikes or lock-outs. It also prescribes the rules and procedures in the violation of the Labor Code, either by the employer or employee (Republic of the Philippines, 1974). However, the provision of this law mainly covers permanent or regular employees.

Pursuant to the said law, tripartism was declared a state policy where employers and workers are to be represented in decision and policy making bodies of the 
government. Towards this end, the head of the Department of Labour and Employment may call upon the representatives of the employers and workers for policy consultation. To ensure that the concerns and requirements of each region are considered, a regional tripartite council was also established. One of their functions is to establish the appropriate minimum wage in their respective regions.

About a year after the enactment of the Labor Code, the 13 Month Pay Law was passed. This statute requires all employers to pay their employees a thirteenth month pay equivalent to not less than one-twelfth of the total basic salary earned by an employee within a calendar year (Republic of the Philippines, 1975).

\subsubsection{Phase IV: Liberalisation and Worker Protectionism (1986-2004)}

When Corazon Aquino (1986-1992) succeeded Ferdinand Marcos as president of the Philippines, she attempted to improve the economy with the assistance from the International Monetary Fund (IMF). This also meant following the IMF's required structural adjustment policies. These policies pushed the government to trade liberalisation in the form of tariff reductions, privatisation and capital account liberalisation (Lim \& Bautista, 2002).

In the Fourth ASEAN Summit in 1992, the Philippines, along with other ASEAN members, agreed to establish an ASEAN Free Trade Area (AFTA) by 2008. The commitments were basically to reduce tariffs. For sugar, the Philippines committed to reduce tariff to $5 \%$ by 2010 (which as earlier mentioned, was later rescheduled to 2015). In 1994, when the World Trade Organization was created, the Philippines became a founding member.

To revitalise the sugar industry, President Aquino created the SRA which took over the PHILSUCOM in 1986. It was mandated to establish a production and marketing system that would be profitable to sugar producers and fair to consumers. The NASUTRA was abolished and all its assets including those of PHILSUCOM were given to SRA. In comparison, the PHILSUCOM was governed by the Commissioner and Associate Commissioners who were all appointed by the president while the SRA is 
governed by the Sugar Board composed of the SRA Administrator as chairman and two board members. Although all of the board members are still appointed by the president, the two board members should represent the sugar planters and the sugar millers. Most importantly, these representatives must be nominated by their respective sectors (Republic of the Philippines, 1986). A year after, the Secretary of the Department of Agriculture (a presidential appointee) became the ex-officio chairman by virtue of The Revised Administrative Code of 1987 (Republic of the Philippines, 1987a).

The SRA Administrator remains as a board member and heads the day to day operation of the SRA according to the policies set and the programmes approved by the Sugar Board. The administrator is assisted by permanent government employees of the SRA. The SRA has three main departments: 1) the Administrative and Finance which handles the administrative work; 2) the Regulation which records, processes and monitors domestic sugar transactions and sugar imports and exports; and 3) the Research Development and Extension whose function is to promote efficient sugar farming through research and knowledge and technology transfer to the sugar farmers (Republic of the Philippines, 1986). Figure 4 shows the SRA's organisational structure. 
Figure 4. The SRA's Organisational Structure

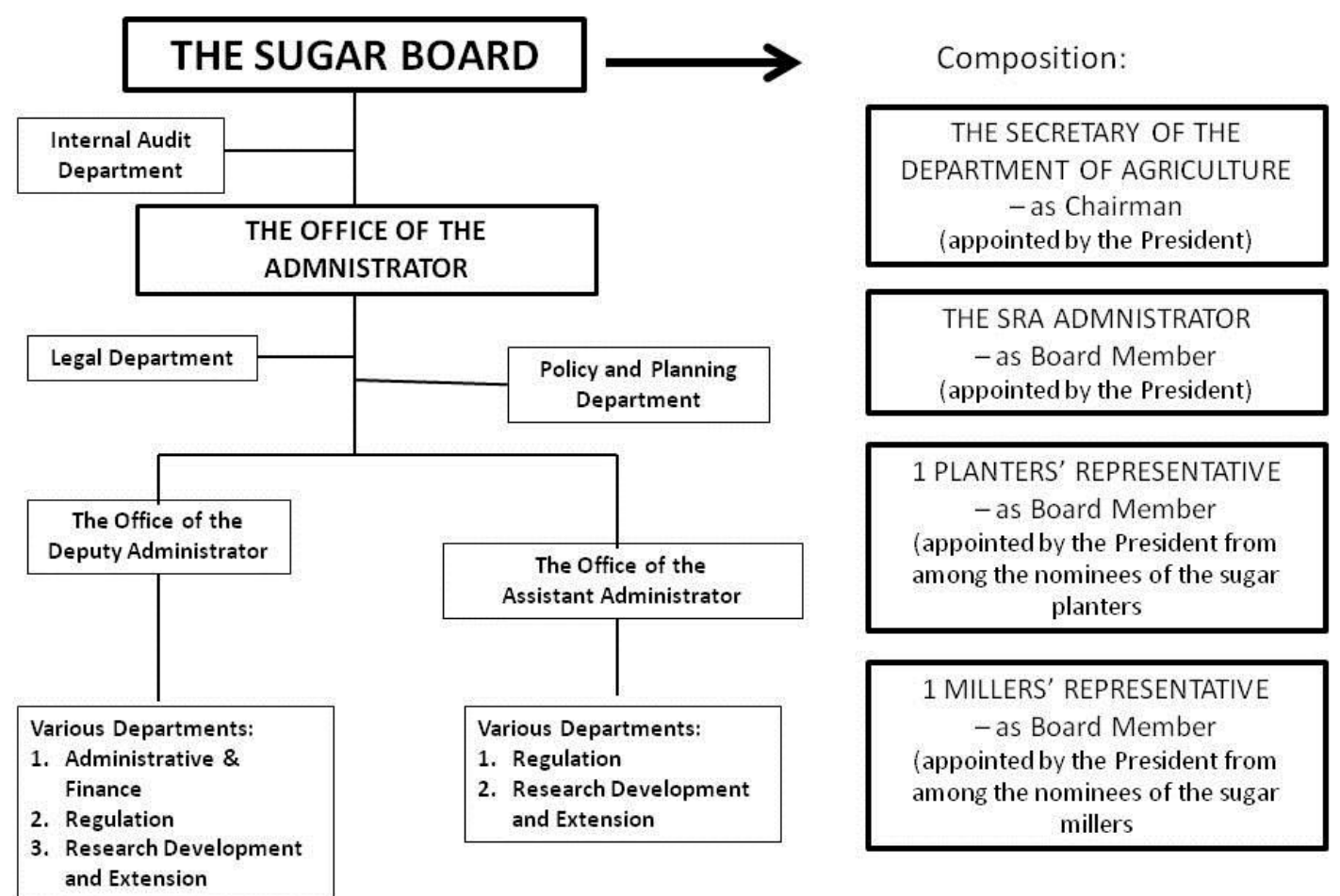

Source: Adapted from the SRA (2012b).

Although the declaration of policy in the SRA charter states that it is the states' policy "to improve the working condition of laborers" (Republic of the Philippines, 1986, Section 1), it does not provide the Sugar Board the function directly related to the workers or improve their work conditions. Chart 1 also reveals that the workers are neither represented on the Sugar Board nor there is any department that caters to their welfare.

However, the current (1986) Constitution of the Philippines recognises labour as a "primary social economic force" (Republic of the Philippines, 1987b, Section 18, Article 2). According to Bitonio (2008), Philippine laws have been based on equity and social justice and labour standards have been largely influenced by the International Labour Organisation (ILO) since it became a member in 1948. Currently, ILO records (ILO, 2012c) show that the Philippines ratified 35 ILO conventions, 34 of which are in force. Eleven of these conventions were ratified 
between 1990-2012. These are the freedom of association and protection of the right to organise in 1953), tripartite consultation in 1991, the equality of treatment (Accident Compensation) in 1994, and the Maintenance of Social Security Rights in 1994. Furthermore, during the period 1986-2000, two important labor laws (listed below) were passed to provide protection to sugar workers.

\subsubsection{The Comprehensive Agrarian Reform Law (CARL)}

The state has declared that

The welfare of the landless farmers and farm workers will receive the highest consideration to promote social justice and to move the nation towards sound rural development and industrialization, and the establishment of owner cultivatorship of economic-sized farms as the basis of Philippine agriculture (Republic of the Philippines, 1988. Section 2).

Pursuant to this, the CARL was passed in 1988 to minimise the inequitable distribution of land. Under this programme, individuals are only allowed to own a maximum of five hectares plus three hectares per child over 15 years of age who is also working on the farm. Any excess area shall be bought by the government and distributed (by means of long term purchase agreements) to the existing farm workers (Republic of the Philippines, 1988). While there were those who have voluntarily offered to sell their farms to the government, there were sugar farms which were subjected to compulsory acquisition under the CARL programme. This fragmented large sugar farms to small ones. A representative from the sugar planters (Personal communication, August 2, 2010) claimed that this prevented some sugar planters from capitalising on economies of scale while some sugar planters hesitated to further invest in the mechanisation of their farms.

\subsubsection{The Social Security Act of 1997}

The Social Security Act of 1997 strengthened the provisions of the old Social Security Law of 1954 as amended by Presidential Degree 1973. It increased the amount of contribution and benefits and extended the coverage to self-employed individuals (Republic of the Philippines, 1997). As in the old law, it mandates the compulsory social security coverage of all workers not over 60 years of age who 
work in the private sector. It requires employers to remit to the Social Security System (SSS) their joint (both employer and workers) monthly contribution in an amount set by the SSS to a provident fund (Republic of the Philippines, 1997). This provident fund is the source for the payment of benefits of the employees which includes:

(1) A monthly pension in case of disability resulting in the cessation of work or to the worker's survivors in case of death, for workers who have at least made 36 monthly contribution with SSS prior to the disability or death, or

(2) A monthly pension for retirees at the age of 60 for workers who have at least made 120 monthly contributions.

(3) Daily sickness benefit to workers confined in a hospital for more than three days in an amount equivalent to $90 \%$ of his average daily salary credit but not to exceed 120 days within a calendar year, for workers who have at least had three monthly contributions in the 12-month period immediately before the semester of the sickness.

(4) Maternity leave pay of $100 \%$ of her average daily salary credit for 60 days

(70 days in case of caesarean) for female workers who have at least made three monthly contributions with the SSS for her first four deliveries or miscarriages.

(5) Financial assistance for the funeral expenses upon the death of a member including a permanently disabled member or retiree.

\subsubsection{The Republic Act 6982 or the Sugar Amelioration Act of 1991}

The Sugar Amelioration Act mandates a lien ${ }^{12}$ of PhP10.00 per picul or PhP7.9051 per 50 kilo-bag of sugar from the sugar produced for the social amelioration fund (Republic of the Philippines, 1991). Eighty percent of the fund is distributed to the sugarcane workers through their employers at the end of every crop year as financial assistance to the sugarcane workers during the off-milling season. The $20 \%$ balance is intended for socio-economic projects to fund the sugar workers

\footnotetext{
${ }^{12}$ Liens are mandated or voluntary amounts written on the face of the warehouse receipt which must be paid before sugar can be withdrawn from the sugar mill. The Philippine National Bank and the Sugar Regulatory Administration are the usual collecting agents of these liens.
} 
maternity benefit, sugar workers death benefit, socio-economic projects (e.g. through the Sugar Industry Foundation, Inc.'s housing, livelihood, scholarship and training programmes, among others), and for administrative expenses. The Department of Labor and Employment (DOLE) is the depository agency of this fund. It facilitates the distribution of the funds to sugar farm workers. The amount distributed is based upon the production of the sugar planters (based on mill records) and the number of their workers. To facilitate release of the fund, the sugar planters are required to provide the DOLE of a list of their workers during the crop year (Republic of the Philippines, 1991). However, based on the Fourth Quarter of 2010 report of the Bureau of Labour Relation (2010), more than 52.6 million Philippine peso (more than US\$1.23Million) ${ }^{13}$ remained undistributed to sugar workers. This implies a problem in the implementation of the law.

It is evident that the sugar industry had been greatly affected by the international trading of sugar even before the Philippine government subscribed to trade liberalisation policies. Fluctuations in the sugar export demand, specifically from the US mainly caused the growth or decline of sugar production. However, trade liberalisation evidently affected the sugar industry in 1992 when the Philippine government joined AFTA and agreed to reduce its sugar tariffs. It was within this period (1990s) that the Philippines' rank six among the world's top sugar producers and later dropped to 11 .

During the times when sugar production became less profitable, government intervened by creating an agency now called the Sugar Regualtory Administration (SRA). The Sugar Board of the SRA has two employers' representatives; however, there no workers' representation. So workers' welfare is pushed through legislation.

The next section provides differences between the employers and the workers in terms of governance structure of the sugar industry.

\footnotetext{
${ }^{13}$ The actual amount is $52,638,589.10$ Philippine pesos. The conversion rate used is US\$1:Php42.772 as on 23 February 2012 (Bangko Central ng Pilipinas, 2012).
} 


\subsection{The Governance Structure of the Sugar Industry}

In the Philippine sugar industry, the main actors are the employers, the workers, and the government and its agencies and instrumentalities. The actions of the government which were discussed in the previous sections mainly focused on the creation and re-shaping of agencies and the issuance of laws for the protection of the workers. Thus, this section will focus on the two other actors: the employers and the workers. It will describe the structure of the employers and the workers as well as the implications of such a structure.

\subsubsection{The Employers' Structure}

There are two types of employers in the sugarcane industry. The first type is the owner of the sugarcane farms who is commonly referred to in the Philippines as 'the sugar planters'. With regard to the milling contract, the sugar mills generally require a sugar planter to affiliate with one of the sugar associations before it accepts the sugarcane for milling. Hence, the sugar planters become members of a planters' association which serves as their representative body to the sugar mill. The workers of the planters' association then serve as the watchdog for the sugar planters, seeing to it that their canes are weighed correctly and that they get their correct share of the sugar produced. A large majority of these planters' associations also form federations which represent the sugar planters at the national level.

The second type is the owner of the sugar mills who is commonly known as 'the sugar millers'. Sugar mills may either be stand-alone ${ }^{14}$ or with refinery. ${ }^{15}$ According to a representative of the sugar millers, the majority of the sugar mills have also organised themselves and form associations at the national level. The Philippine Sugar Millers' Association (PSMA) represents the most number of sugar mill members (PSMA, 2011b) while the Philippine Sugar Refineries (PASRI) represents the sugar refineries (Mike, personal communication, 2011).

\footnotetext{
${ }^{14}$ Stand alone mills are those that do not have an adjunct refinery and therefore produces only raw sugar.

${ }^{15}$ Refers to mills that have an adjunct refinery and therefore also process raw to refined sugar.
} 
Currently, there exist approximately five sugar planters' federations covering more than $80 \%$ of the sugar planters. Together with the PSMA and the PASRI, they formed the Sugar Alliance of the Philippines (SAP) whose total membership comprises about $90 \%$ of all the sugar producers (employers) (Peter, personal communication, August 2, 2011). The SAP is an umbrella organisation of sugar producers established to promote the common interest of sugar producers amongst which is the need to address the viability and survival of the sugar industry. It serves as the consultative body to the government especially in the formulation of sugar policies issued by the SRA. The funds of this organisation come from contributions of its members from their sugar produce. Its lobbying arm extends not only in the Philippines but in other countries (Peter, personal communication, August 2, 2011). This reflects a united, hence strong employers' structure when it comes to bargaining. Figure 5 illustrates the employers' organisational structure for policy consultations.

Figure 5. The Employers' Policy Consultation Structure

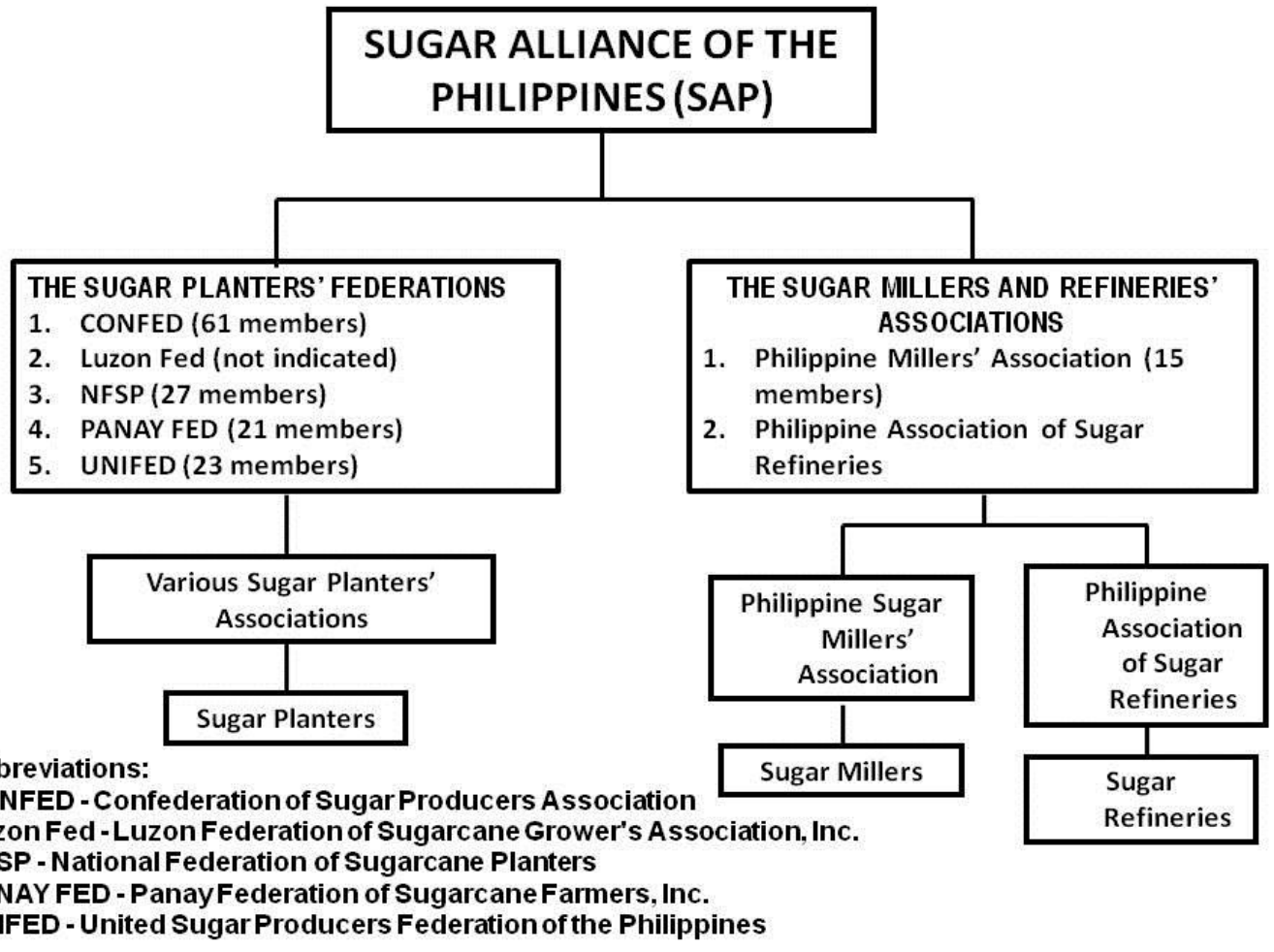

Source: Illustration based on interview with the government sector representative. Number of members was taken from SRA (2012a) and PSMA (2011b) websites. 
According to a representative from the planters' federation, most sugar planters voluntarily contribute to the social projects for their workers. These projects include among others, scholarship of the workers' children and supplementary livelihood programmes through their chosen industry specific non-government organisations such as the Sugar Industry Foundation, Inc., the NFSP and the UNIFED foundations. The employers' representative added that whenever sugar prices are high, most sugar planters give additional monetary benefits to their workers during Christmas season (Peter, personal communication, August 2, 2010). This means that part of the social benefits of the workers is dependent upon the profits of their employer. This makes the granting of these benefits uncertain.

\subsubsection{The Labour Union Structure}

The workers' right to organise, form labour unions and associations and exercise these rights are provided in the law. The Philippine Constitution declares that the state "shall guarantee the rights of all workers to self-organization, collective bargaining and negotiations" (Republic of the Philippines, 1987). Under the Philippine Labor Code however, a labour union acquires legal personality only after successful registration with the Department of Labor and Employment (DOLE) and upon proof that its members comprise at least $20 \%$ of the workers of an establishment. Once duly registered, the labour union then acquires the right to bargain with the employer. If a company has two or more unions, the unions have to compete in a certification election. The union which receives the majority votes of the workers becomes the sole bargaining agent for all the workers (Republic of the Philippines, 1974).

According to the DOLE, there are different types of labour unions. At the enterprise or local level, unions may either be an independent union or a local chapter (a branch of a national union or union federation). An independent union is one which has registered with the DOLE independently from an existing national or federation union. A local union on the other hand is an extension of a registered union federation or national union which issued it a charter certificate. The law requires a 
minimum of ten enterprise-level unions to form a union federation or national union. Trade union centres on the other hand comprise of union federations and national unions. They were organised for policy consultations to protect and aid its members. Unions may cater specifically to a single sector or industry or a multisector. Based on this information, the trade union structure is illustrated in Figure 6 with the corresponding number of unions taken from the Bureau of Labour Relations' (BLR) records.

Figure 6. Trade Union Structure Based on Affiliation

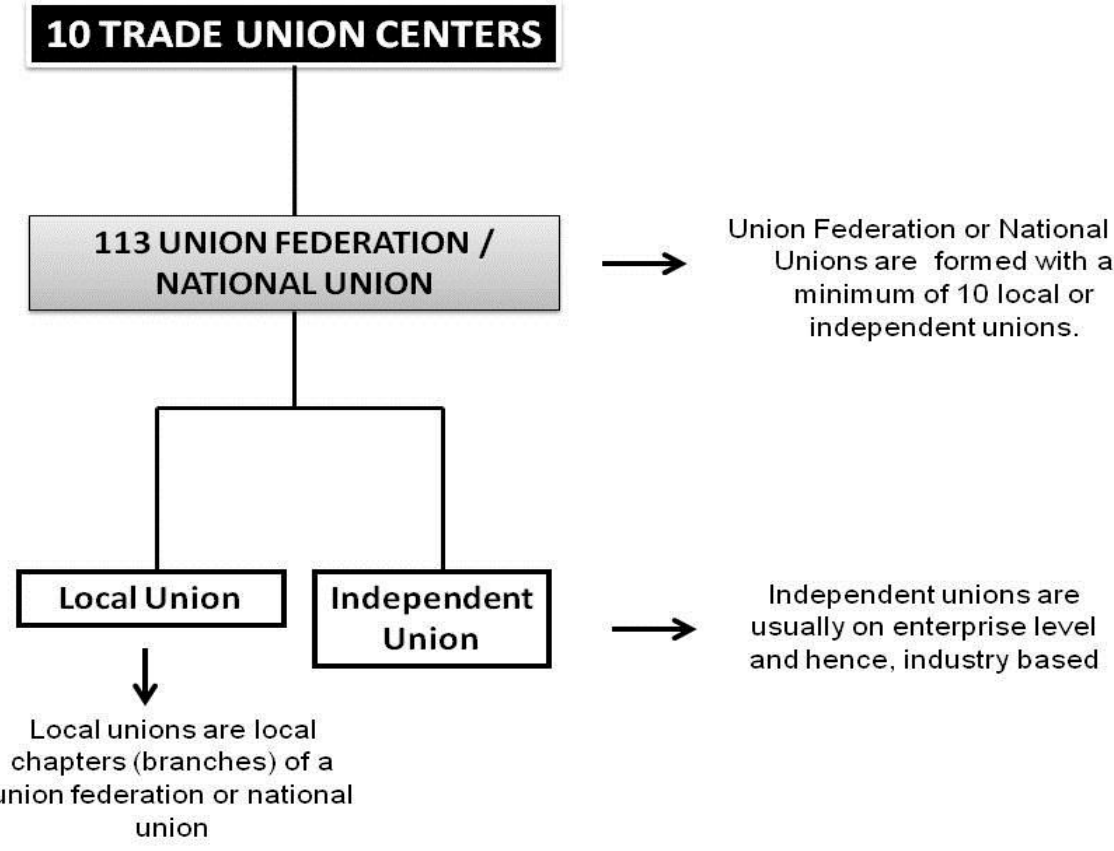

Source: Illustration based on affiliation of unions per records of BLR (2012a; 2012b).

Workers have representatives both at the workplace and at the national level. According to a national level union representative, sugar mill workers are generally unionised (Urbano, personal communication, September 24, 2011). They receive regular legal advice from lawyers of their affiliated national-level union. The workplace-level or enterprise-level union activities, however, are concentrated on collective bargaining agreements. The national issues of workers are generally left to their affiliated union federations or national unions to resolve. In addition, the welfare of workers in all sectors may also be pushed in Congress by elected labour 
party-list representatives. Every national election, marginal sectors, which include labour, may run as party-list representatives and, upon garnering the required minimum number of votes, become elected members of Congress. According to the trade union representation, there are numerous labour parties who run for partylist representatives every election. In fact, in the May 2010 election, out of more than 180 party-list candidates competing for about 52 seats in Congress, there were at least 12 party-list groups that came from the workers of various sectors (Philippine Commission on Election, 2010). This meant that the workers' votes were split, thereby weakening the chances of labour parties of being elected. Hence, to gather more votes, the labour parties do not limit its membership to a single industry (Urbano, personal communication, September 24, 2011). This implies an absence or limited workers' representation on a sectoral basis.

\subsubsection{The Sugar Industry Labour Force}

Sugar farm workers significantly outnumbered sugar mill workers. The latest available Bureau of Rural Workers (2010) report revealed that the sugar industry employed a total of 700,000 workers in $2007-2008$. Of these, almost 692,000 or more than $98 \%$ are field or farm workers and the rest are sugar mill workers. Hence, when talking about the sugar industry workers, it is generally attributed to farm workers.

Sugar production is seasonal in nature. The sugar crop year officially starts in September and ends in August. The period from October to May is considered the milling season while the period from June to September is referred to as the 'dead season'. It is called the dead season because in sugar farms, about $90 \%$ of the workforce has no work. This is the time when the sugarcane awaits its maturity for harvest. However, for mill workers, work continues during off-milling season. A mill manager (Anton, Personal communication, September 7, 2011) relayed that repairs and maintenance of equipment are being carried out for the next milling season. This means that the seasonal nature of sugar farming has no significant effect on the workload of sugar mill workers. 
In general, this section demonstrates that the employers have a structured and united organisation as evidenced by the formation of the SAP, the employers' umbrella organisation covering about $90 \%$ of all the sugar producers. Hence, they are well represented in the formulation of government policies and have the financial means to pursue and secure their interests. On the workers' side, the large number of trade union centres at the national level shows a divisive structure. Despite the presence of labour leaders in the government through the party-list representatives, the election process has promoted multi-sectoral interests hence, there is limited industry-specific or sectoral representation at a national level. However, in the aspect of improving their welfare, it is also worth noting that the employers have organisations and foundations that provide programmes and activities for the welfare of their workers and their dependents. This implies that the employers play an important role in improving the work conditions of their workers.

\subsection{The Sugar Production Process, Classification and Distribution}

This section describes the sugar production process, the sugar classification and distribution system. The purpose of this section is to show the uniqueness of the Philippine sugar industry which has shaped the production and trading of sugar as well as the roles played by the different actors in the industry.

\subsubsection{The Sugar Production Process}

Figure 7 shows the raw sugar production process from land preparation to sugar production. 
Figure 7. The Raw Sugar Production Process
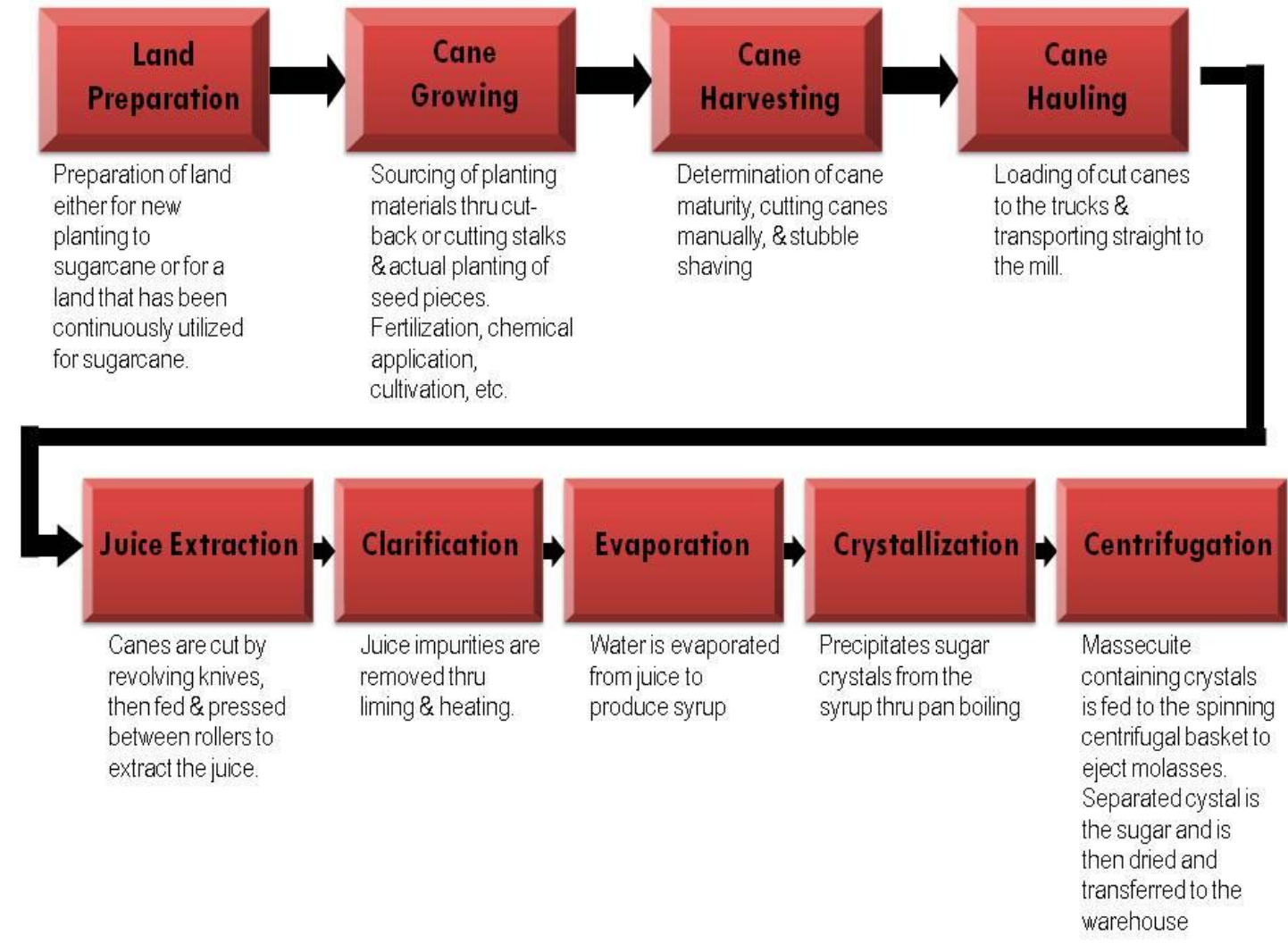

Source: Amarra, personal communication, July 11, 2011.

From the sugar farms, sugarcane is delivered either by a train cart using the sugarcane railway (railways cut across many sugar farms) or by delivery trucks taking the regular roads. The canes received are weighed and later shredded. The shredded cane is then crushed to extract the juice. A small portion of the juice is analysed to determine the sugar content. ${ }^{16}$ It is heated and limed and the advances to the clarifier for the dirt removal. The clear juice proceeds to the evaporator where the water is removed through steam to form the syrup. Next, the syrup goes to the vacuum pan where sugar crystals are produced. After that, the sugar is separated from the (molasses) syrup then dried and transferred to the warehouse where it is either stored in bulk or bagged in 50-kilo bags.

\footnotetext{
${ }^{16}$ The weight of the sugarcane and the sugar content are the major factors that determine the total sugar produced from the sugarcane delivered by a sugar planter
} 


\subsubsection{The Sharing System}

The sugar mills in the Philippines generally (with very few exceptions) do not purchase sugarcanes. When sugarcanes are received by the mill, in lieu of payment, the sugar mill receives a share of the sugar produced. The sugar planters' share is around $70 \%$ while the sugar millers receive the remaining $30 \%$. This allows the sugar millers to accommodate as much cane as it can without regard to capitalisation for the purchase of cane (Amarra, personal communication, July 21, 2011).

\subsubsection{Sugar Trading}

The sugar produced is not directly and physically handed to sugar planters. The share of the produce of the miller and the sugar planter is recorded on the day the sugarcane is processed and a report is distributed every week. The sugar remains at the mill warehouse ${ }^{17}$ and the owners are issued a sugar quedan (Amarra, personal communication, July 11, 2011). A picture of a sugar quedan is attached in Appendix M.

The sugar quedan (see Appendix $\mathrm{N}$ for a photo of a sugar quedan) is a type of warehouse receipt which specifies the volume and classification or market destination of the sugar stored in favour of someone. This quedan is the instrument used for trading sugar. To receive the physical sugar, the holder of the sugar quedan ${ }^{18}$ first has to pay specified liens on the quedans (e.g. storage fee, insurance fee, social amelioration fee, etc.), then surrenders the quedans at the sugar mill and the mill will then release the physical sugar (Amarra, personal communication, May 17, 2011). This raw or brown sugar is generally sold to a sugar trader for export overseas or processing in a refinery for domestic consumption. Figure 8 illustrates the sugar commodity flow from farm to market.

\footnotetext{
${ }^{17}$ Storage is free for the first 60 days and a minimum fee is charged thereafter.

${ }^{18}$ Holders of sugar quedans are usually sugar traders purchasing quedans in volume through planters' associations or from mills.
} 
Figure 8. The Sugar Commodity Flow (Farm to Market)

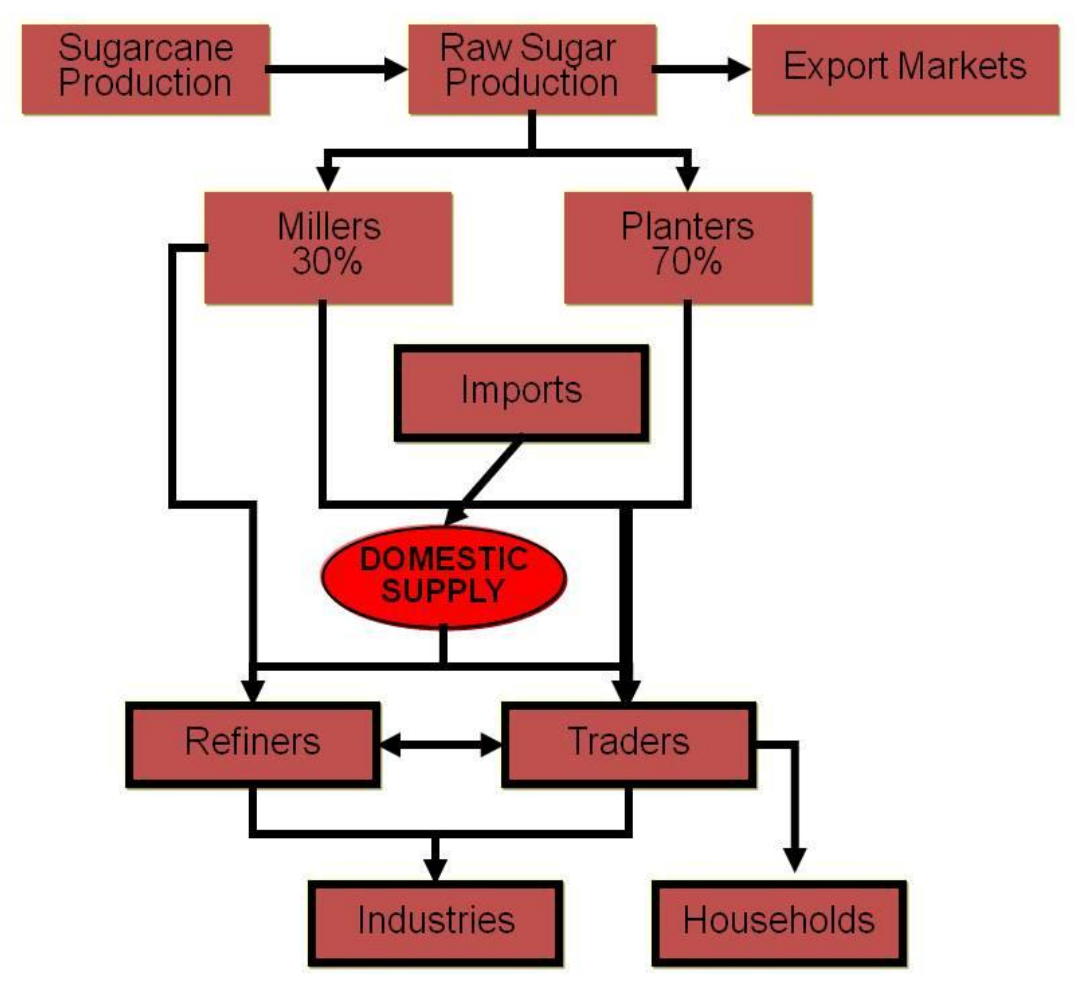

Source: Amarra, A. Personal communication, July 11, 2011.

As shown in the illustrated commodity flow diagram, the sugar industry is a buyerdriven industry. The role of sugar traders becomes important in establishing linkages with production networks in different areas (Gereffi, 2001). The sugar producers have no greater or lesser leverage over forward linkages. Sugar is supplied by local manufacturers and is distributed to the traders who distribute it to retailers or ship it for export. Furthermore, as in buyer-driven commodities there is a low barrier of entry to sugar production (Gereffi, 2001).

\subsubsection{The Sugar Classification System}

Sugar prices vary according to market destinations. However, sugar mills do not compete for markets (domestic or international). Amarra (Personal communication, May 17, 2011) explained that at the beginning of the crop year, the government, through the SRA, estimates the total production and consumption for the year. Based on its estimates and after consultation with sugar producers (millers and 
farmers), it issues an order mandating the sugar percentage classification according to market destination. Sugar produced by each mill and farmer is quedanned according to this mandated percentage classification. This percentage allocation may be revised at certain periods depending upon supply and demand. Basically, Philippine sugar has four classifications. The first classification is the ' $A$ ' or 'US quota sugar' which is allocated for export to the US under the US quota system. The volume of this sugar is based upon the quota granted by the US to the Philippines and is announced before the start of the crop year. Under this agreement, Philippine sugar enters the US tariff-free. ' $A$ ' or US quota sugar prices are generally higher than world market prices. The second classification is the ' $B$ ' or 'Domestic sugar' which is allocated for domestic (Philippine) consumption. 'B' or Domestic sugar prices are generally higher than world market prices. The third classification is the ' $C$ ' or 'Reserved sugar'. This sugar cannot be withdrawn from the sugar warehouse unless the SRA declares its final classification, thus the term 'reserved'. ' $C$ ' sugar is usually issued during peak production periods in order to regulate sugar supply. The expected surplus of production (net of estimated domestic supply needed and the US quota) is the fourth classification, ' $D$ ' or 'World market sugar'. This is allocated for world market export other than the US under the US quota system. Figure 9 illustrates the sugar classification system applied to a sugar planters' raw sugar production of 100 50-kilo bags. ${ }^{19}$

\footnotetext{
${ }^{19}$ Sugar is generally bagged in 50 kilo lots.
} 
Figure 9. Illustration of the Sugar Classification System.

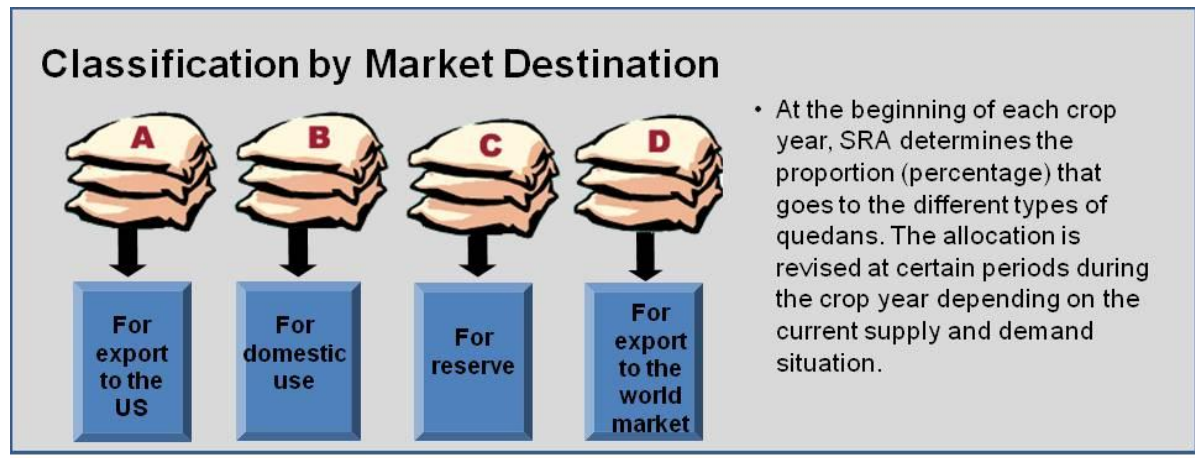

Illustration of the quedanning of 10050 -kilo bags produced by a sugar planter (representing his $70 \%$ share) where the allocation is :
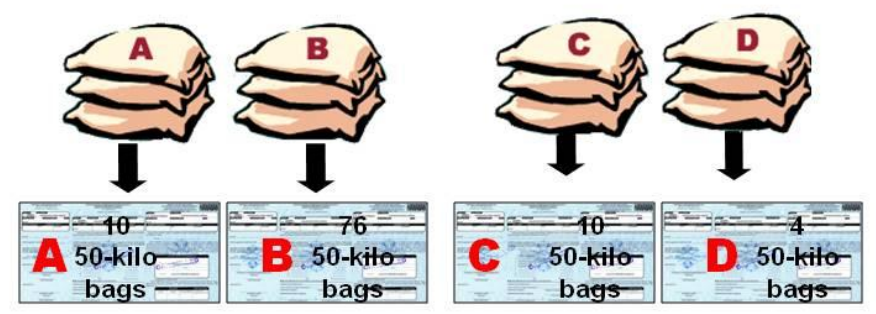

$$
\begin{aligned}
& \text { A- } 10 \% \\
& B-76 \% \\
& C-10 \% \\
& D-4 \%
\end{aligned}
$$

Source: Amarra, A. Personal communication, May 17, 2011.

Only sugar traders registered with the SRA are allowed to trade sugar unless sugar is withdrawn by the sugar planter himself/herself. In the latter case however, withdrawal of sugar is only considered for personal or family consumption, hence only at a minimum quantity. A government sector representative (Gabriel, Personal communication, August 9, 2011), explained that for logistic purposes, sugar traders are allowed to swap the classification of the quedans to position their sugar to specific market destinations. For instance, a trader has 10 tons of ' $A$ ' (US quota sugar) and 10 tons of ' $B$ ' (Domestic sugar) quedans from Visayas Mill which is located in the centre island of the Philippines. This mill is nearer to a loading port for export. Likewise, the trader has 10 tons of ' $A$ ' and 10 tons of ' $B$ ' sugar quedans from Luzon Mill which is located in the northern island of the country where most of the ' $\mathrm{B}$ ' sugar (domestic) is consumed. The trader wishes to export to the US his/her 20 tons of ' $A$ ' sugar (note that only ' $A$ ' sugar can be used to withdraw sugar for the US market). As illustrated in Figure 10, the trader will swap his/her 10 tons of 'B' Sugar Visayas Mill to 'A' Sugar of Luzon Mill. The trader then ends up with two 10 tons (a total of 20 tons) ' $A$ ' Sugar all in Visayas Mill and two 10 tons (a total of 20 tons) 'B' Sugar all in Luzon Mill. It is now easier for the trader to ship the sugar to 
the US because he/she can now withdraw the whole 20 tons of ' $A$ ' sugar from a single mill, Visayas Mill. Likewise, the trader can also sell all his/her ' $B$ ' or 'Domestic sugar' to the north island which is a larger market for domestic sugar.

Figure 10. Illustration of Sugar Swapping

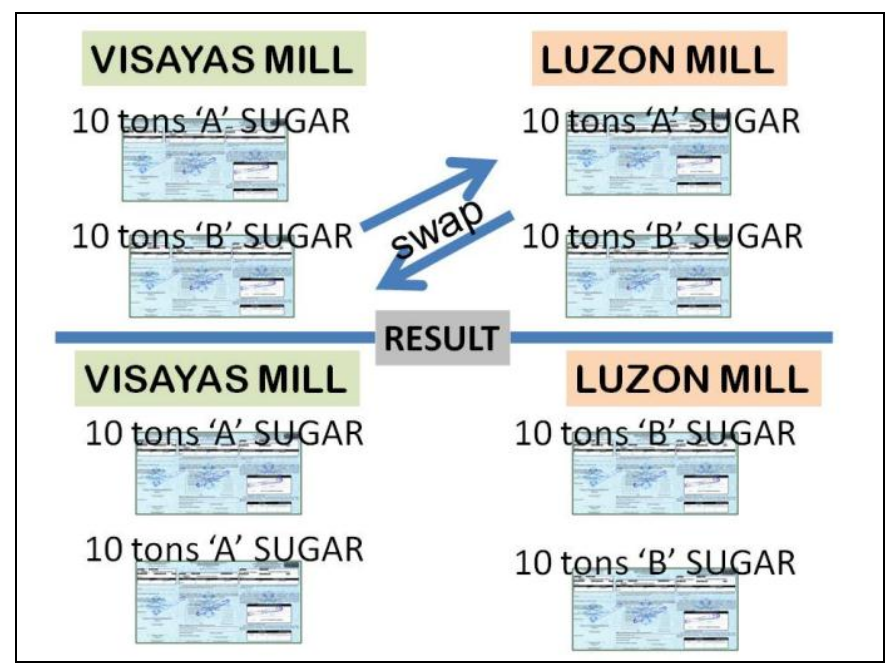

Source: Gabriel, personal communication, August 9, 2011.

On one hand, the sugar allocation system ensures that sugar producers get equal share in the different market destinations (domestic, US and world export). However, the volume of a mill's production is the only factor in classifying the sugar market destination while sugar quality is not taken into consideration. On the other hand, the provision of the reserve sugar (' $C$ ' sugar) prevents the overflooding of supply in the local market. All these show that the Philippine sugar industry is a government regulated and protected industry with the SRA playing an important role.

\subsection{The Philippine Sugar Industry in the Global Setting}

Sugarcane and sugar beet plants are the primary sources of sugar for commercial production. But there is no significant difference between sugar sourced from sugarcane and from sugar beet (New World Encyclopedia, n.d.). Nyberg (n.d.) reported that about $75-80 \%$ of the world's commercially produced sugar is from 
sugarcane and only about $20-25 \%$ is sourced from sugar beet. This research is focused on sugar sourced from sugarcane.

To situate the Philippine sugar industry in the global setting, the latest Food and Agricultural Organisation Statistics (FAOS) (2012) record of the top 15 sugar producers from 1984-2009 with a five-year interval is presented in Table 7. It shows that the Philippine's ranking had declined from six in 1984 to 11 or 12 in the 1990s. The Philippines' rank had again shown signs of improvement in 2004 and had gained rank 8 in 2009.

Table 7. Top 15 Sugar (cane) Producers

\begin{tabular}{|l|r|r|r|r|r|r|r|}
\hline \multicolumn{1}{|c|}{ COUNTRY } & $\mathbf{1 9 8 4}$ & \multicolumn{1}{|c|}{$\mathbf{1 9 9 0}$} & $\mathbf{1 9 9 4}$ & $\mathbf{1 9 9 9}$ & $\mathbf{2 0 0 0}$ & $\mathbf{2 0 0 4}$ & $\mathbf{2 0 0 9}$ \\
\hline Argentina & 14 & 14 & 14 & & 14 & 13 & 10 \\
\hline Australia & 8 & 12 & 9 & 7 & 7 & 8 & 9 \\
\hline Brazil & 1 & 1 & 1 & 1 & 1 & 1 & 1 \\
\hline China & 4 & 4 & 3 & 3 & 3 & 3 & 3 \\
\hline Colombia & 11 & 9 & 10 & 9 & 10 & 7 & 7 \\
\hline Cuba & 3 & 3 & 5 & 8 & 8 & 12 & 17 \\
\hline Dominican Republic & 15 & & & & & & \\
\hline Egypt & & 15 & 15 & & & & \\
\hline Guatemala & & & & 15 & 15 & 14 & 14 \\
\hline India & 2 & 2 & 2 & 2 & 2 & 2 & 2 \\
\hline Indonesia & 12 & 8 & 8 & 12 & 12 & 11 & 12 \\
\hline Mexico & 5 & 5 & 6 & 6 & 6 & 6 & 6 \\
\hline Pakistan & 7 & 6 & 4 & 4 & 5 & 5 & 5 \\
\hline Philippines & 6 & 11 & 12 & 11 & 11 & 9 & 8 \\
\hline South Africa & 13 & 13 & 13 & 13 & 13 & 15 & 13 \\
\hline Thailand & 10 & 7 & 7 & 5 & 4 & 4 & 4 \\
\hline U.S.A. & 9 & 10 & 11 & 10 & 9 & 10 & 11 \\
\hline Vietnam & & & & 14 & & & 15 \\
\hline Source: FAOS & & & & & &
\end{tabular}

Source: FAOS (2012)

Generally, the world is producing more sugar than it consumes. The Foreign Agriculture Services (FAS) (2010) projected that for the crop year 2010-2011, world sugar production will reach 164 million tons raw value while consumption will be about 158 million tons. The FAS estimated that most of the sugar will come from 
Brazil, contributing to about $25 \%$ of the world's production while Asia will provide about 38\% (FAS, 2010). The Philippines belongs to the top ten sugar (from sugarcane) producing countries according to the 2005 report (which is the latest year posted) of the FAO (2011). However, world sugar production may decrease because of climatic changes and natural disasters. For instance, hurricane Katrina in 2005 which hit Louisiana resulted in the closure of some sugar refineries in that area (Economic Research Service, 2006). Tropical cyclone Yasi likewise caused damage to the sugar producing areas in Queensland, Australia (Foreign Agricultural Service, 2011). These climatic disasters caused the decrease in world sugar production which resulted in soaring world sugar prices. This implies that sugar in the world market is characterised by fluctuations in sugar supply and prices.

\subsubsection{Trade Distorting Practices}

Sugar price volatility is not only caused by the fluctuation of sugar supply. Distortion is also caused by government support to farmers in the form of guaranteed minimum prices, production and marketing controls and high tariff rates among others (Nyberg, n.d.). Furthermore, sugar trading is not only determined by costefficiency but also by preferential trade agreements. Among the main trade agreements are those of the European Union (EU) and the United States (US). For instance, the EU preferential trade agreement with Fiji has been the major reason for Fiji's sugar industry profitability whereby the EU pays a subsidy on imported Fijian sugar (Szmedra, 2004). This raises the purchase cost of Fijian sugar at levels higher than world market prices. Likewise, the US, which is among the major importers of sugar, also practices preferential treatments through a Tariff Rate Quota (TRQ) system. US domestic sugar prices are generally much higher than the world market prices. Hence the US government imposes very high tariff rates to protect its local producers. However, sugar under the TRQ enters the US with no or relatively low tariff rates (Skully, 1998). Among the beneficiaries of these TRQ is the Philippines, a former colony of the US. This is favourable to the Philippine sugar industry because it has a steady market although its cost of production could not compete with other more efficient sugar producing countries such as Thailand, Brazil and Australia. 


\subsubsection{The Challenge Faced by the Philippine Sugar Industry}

The Philippines produces more than enough sugar for domestic consumption (Sugar Regulatory Administration, (SRA) 2010). For the crop year 2009-2010, about $10 \%$ of the Philippines' total raw sugar production of 1.97 million metric tons had been allocated for export (SRA, 2010). A government official (Gustav, personal communication, November 4,2011 ) related that due to the high cost of production, the local sugar producers are currently threatened by cheap sugar imports. For now, the tariff on imported sugar imposed by the Philippine government sustains the level of prices which are profitable to farmers when their sugar is sold at the domestic market. This is so because although sugar prices at world market are lower than domestic prices, when sugar is imported, the tariff adds up to the cost of imported sugar, thereby making domestic sugar prices competitive.

The government official (Gustav, personal communication, November 4, 2011) also reported that the sugar industry leaders and the SRA performs anti-smuggling activities. Nevertheless, cheaper sugar from other countries still enter illegally into the Philippines and further pushes the sugar prices down (Gustav, personal communication, November 4,2011$)$. Hence, even tariff rates does not seem to be enough to combat the entry of imported sugar. Sugar smuggling is also one of the problems facing the sugar industry

The Philippine government had initially committed to reduce its sugar tariffs to $5 \%$ in 2010 in the Association of Southeast Asian Nations (ASEAN) Fair Trade Area (AFTA). However, domestic sugar prices remain significantly higher compared to other countries. As a government sector representative explained:

We still cannot compete with world sugar prices.... most of the sugar smuggled caught by our anti-smuggling team comes from Thailand. Which means that Thai sugar prices are much cheaper even if you have to add all those expenses for smuggling.... We are not yet ready for a $5 \%$ to $0 \%$ sugar tariff

(Gabriel, personal communication, August 9, 2011).

Hence, a representative from the sugar planters relayed that the sugar industry lobbied with the government to renegotiate its position in the AFTA on sugar tariff 
reduction. As a result, the Philippines' sugar tariff reduction had been re-scheduled and reduced to $5 \%$ on 1 January, 2015. Table 7 presents the schedule of sugar tariff reductions since 1985. It shows that the reduction of sugar tariffs began in 2004.

Table 8. Schedule of Philippine Sugar Tariffs

\begin{tabular}{|l|l|r|r|}
\hline \multicolumn{2}{|c|}{ Source } & \multicolumn{1}{c|}{$\begin{array}{c}\text { Effective } \\
\text { Year }\end{array}$} & $\begin{array}{c}\text { Tariff } \\
\text { Rate }\end{array}$ \\
\hline Executive Order No. 470 & (Philippine Government, 2004) & 1985 & $50 \%$ \\
\hline Executive Order No. 295 & (Philippine Government, 1991) & 2004 & $48 \%$ \\
\hline Executive Order No. 892 & (Philippine Government, 2010) & 2010 & $38 \%$ \\
\hline Executive Order No. 892 & (Philippine Government, 2010) & 2012 & $28 \%$ \\
\hline Executive Order No. 892 & (Philippine Government, 2010) & 2013 & $18 \%$ \\
\hline Executive Order No. 892 & (Philippine Government, 2010) & 2014 & $10 \%$ \\
\hline Executive Order No. 892 & (Philippine Government, 2010) & 2015 & $5 \%$ \\
\hline
\end{tabular}

In summary, the world has more than enough sugar. Sugar prices at the world market are highly affected by fluctuations in sugar production caused by natural disasters as well as by the trade distorting practices of some countries. Trade distorting practices include trade agreements and domestic control schemes. One of those who benefit from the trade agreement is the Philippines whose sugar enters the US with minimal tariffs. This has been one of the factors that keeps sugar production profitable in the Philippines considering that its cost of production could not yet compete with other more efficient sugar producing countries. Presently, the local industry's major threat is the reduction of the sugar tariff that protects the local sugar industry.

\subsection{The Philippine Sugar Industry's Roadmap to Global Competition}

The SAP designed a strategic programme to prepare the local sugar industry for the reduction of the sugar tariff (Amarra, personal communication, May 17, 2011). It is hoped that the activities and projects will be adopted (adoption is voluntary) by both the sugar farmers and the millers. The programmes which are relevant to this study can be categorised into four areas: 1 ) mill upgrading; 2) tapping other sources 
of revenue from sugarcane; 3) sugar farm expansion; and 4) increasing farm productivity. Each of these strategies is discussed in the next subsections.

\subsubsection{Mill Upgrading}

A government official (Gustav, personal communication, November 4, 2011) argued that most sugar mills were established more than 50 years ago. In order to become globally competitive, these sugar mills must upgrade their technology to increase sugar extraction and recovery, maximise their milling capacity and produce sugar at qualities acceptable to the world market.

\subsubsection{Tapping Other Sources of Revenue of Sugarcane}

The government official also claimed that another strategy to improve costefficiency is to tap other revenues from sugarcane. Sugarcane maybe used for purposes other than sugar production (Figure 11 shows 3 other uses of sugarcane). One of these is ethanol production which is encouraged under the government's biofuel programme. In this programme, the government mandates a required percentage of ethanol to be blended with gasoline. In this connection, a privatelyowned ethanol plant had been built in Negros for this purpose. However, according to a key informant, prices of sugar went up making it unfeasible to buy sugarcane for ethanol production at such high prices. Still, this is a possible alternative market for sugarcane if sugar prices are declining and/or when gasoline prices are soaring. A representative from the government sector explained that the sugar industry must provide a steady supply of sugarcane as feedstock for ethanol in order to sustain the ethanol plant's operation (Gustav, personal communication, November $4,2011)$. If this is supported by other investors, the mills have to compete with the acquisition of raw material (such as sugarcane) which may subsequently affect the mills' volume of production.

Another source of revenue from sugarcane is co-generationm, the government official reported. Bagasse, the fibre left over after the juice has been squeezed out of sugarcane stalks, may be used to produce heat energy. In fact, mills usually 
supply their own power generated from bagasse. This way, the mills will have sources of revenue other than sugar.

Figure 11. Other uses of sugarcane

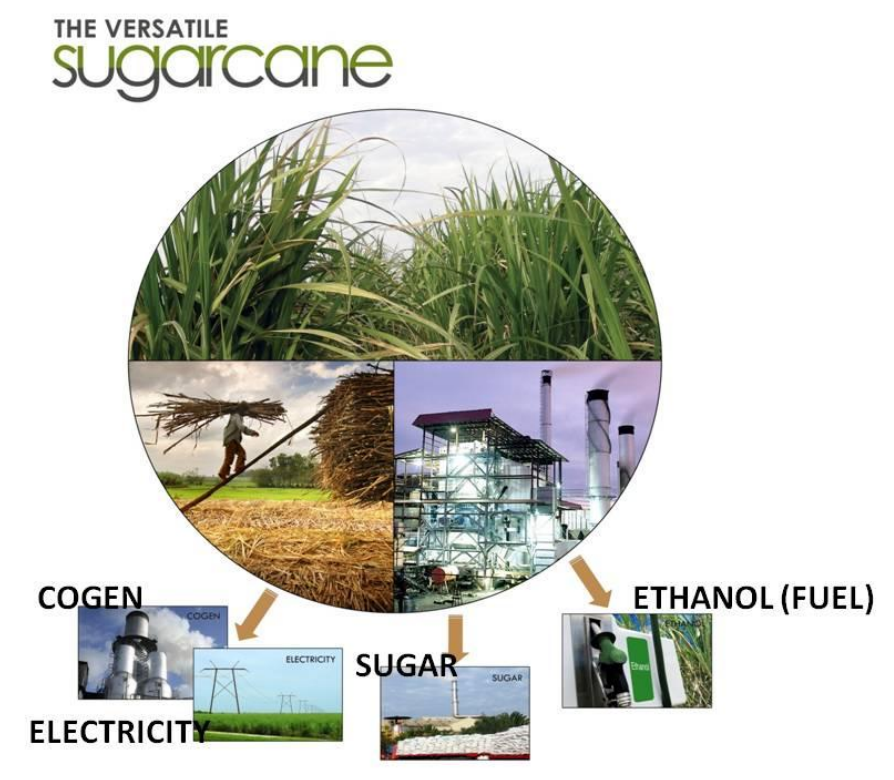

Source: Amarra, personal communication, July 11, 2011.

\subsubsection{Sugar Farm Expansion and Increasing Farm Productivity}

A government official (Gustav, personal communication, November 4, 2011) opined that a steady supply of sugar for export and a cost-efficient production are essential for Philippine sugar to be able to compete globally. She explained that in order for the Philippines to attract sugar buyers from other countries, it has to be able to produce a steady supply of sugar. Hence, one of the industry's strategies is to expand the areas for sugar production. A government sector representative reported that for sustainability, the industry's goal is to have about 400,000 hectares devoted to sugar production and another 50,000 hectares for bio-ethanol use (Gustav, personal communication, November 4, 2011).

The Sugar Alliance of the Philippines pointed out the hindrances to global competition. These are: small farm sizes preventing farm mechanisation, not enough sugar farm areas for both sugar and ethanol production and the high cost 
of production. Likewise, it stated the measures necessary to address these. While some sugar farms and mills had already taken steps to be more competitive (some sugar farms are already using modern farm implements while some sugar mills have upgraded their technology and machinery), these are not enough to improve the productivity and cost efficiency level of the whole industry. These activities must be adapted by all the sugar farms and mills (Gustav, personal communication, November 4, 2011).

\subsection{Summary of Key Findings}

In summary, the Philippine sugar industry has always been affected by the trade interactions between and among nations. It is highly susceptible to fluctuations in the world sugar prices and preferential trade agreements. A large part of its history recorded its dependence on US preferential treatment. The sugar industry evidently is a government protected industry. Protection is generally in terms of sugar tariffs. Furthermore, the SRA also plays a key role in the production and trading of sugar.

The high cost of sugar production became a growing concern in the sugar industry when the government committed to reduce its sugar tariffs in the ASEAN Summit of 1992 as a trade liberalisation reform. In preparation, the sugar producers, through the Sugar Alliance of the Philippines, had mapped out their road to global competitiveness. These strategies include mill upgrading, tapping other sources of revenue from sugarcane, sugar farm expansion, and increasing farm productivity. For now, partial farm and mill mechanisation has been put in place.

With respect to the employers, it is noted that they have a well-structured and wellfinanced organisation for policy consultation. Both the miller and the sugar planters are represented in the SRA Sugar Board. For their social action programmes, the employers established industry specific organisations to improve the welfare of their workers. As far as the workers are concerned, their welfare is generally promoted through legislation. Philippine law prescribes labour standards and procedures from hiring to termination. In the aspect of representation, the findings 
reported that further improvements to workers' conditions are undermined by institutional and structural constraints. For instance, the workers are not represented at the SRA Sugar Board. In addition, the certification election and the party-list representative voting system promote a divisive structure and limited sectoral representation.

The next chapter will look at the workplace and discuss how the changes in the sugar industry have affected decent work in a sugar mill. 


\section{Chapter Five \\ Findings: The Azucarero Sugar Mill}

\subsection{Introduction}

The purpose of this chapter is to reveal the impact of trade liberalisation on the nature and structure of work in a Philippine sugar mill, the Azucarero sugar mill. It focuses on the changes introduced by the mill in their drive towards costeffectiveness. The chapter begins by providing some background to the mill. It describes the traditional set up at the mill before the influence of trade liberalisation. The succeeding sections then highlight the changes at the mill that occurred in response to the government's commitment to reduce sugar tariffs. Primarily, it outlines the technological changes that have taken place and the changes in work structure, the quality of employment, rights at work and avenues of negotiation.

\subsection{Background ${ }^{20}$}

The Azucarero sugar mill was established as a raw sugar mill around 1918 . With the exception of the war years ${ }^{21}$, it has been in continuous production since 1921. A summary of the mill's profile is provided in Table 9.

\footnotetext{
${ }^{20}$ In compliance with the researcher's commitment to a confidentiality agreement with the mill's management, only a limited description of the sugar mill is provided.

${ }^{21}$ Japanese invaded the Philippines in 1942 until 1945 (Zaide, 1994).
} 
Table 9. The Mill Profile

\begin{tabular}{|l|l|l|}
\hline Location & \multicolumn{2}{|c|}{ North-western part of Negros Island, Visayas area } \\
\hline Land area & 45 hectares & 45 hectares \\
\hline $\begin{array}{l}\text { Milling capacity\{1\} } \\
\text { in } \\
\text { tons of cane per day }\end{array}$ & 6,200 until 1992 & $\begin{array}{l}7,500 \text { starting crop year } \\
2008-2009\end{array}$ \\
\hline $\begin{array}{l}\text { Type of workers } \\
\text { Number of } \\
\text { workforce }\end{array}$ & $\begin{array}{l}\text { Started with wholly } \\
\text { employees) workers }\end{array}$ & $\begin{array}{l}\text { In } 2000-350 \text { permanent } \\
24 \text { contractual }\end{array}$ \\
\hline $\begin{array}{l}\text { Nermant (direct } \\
\text { Source: Anton, personal communication, September 7, 2011. }\end{array}$ \\
$\begin{array}{l}\text { \{1\}- Nationwide, for crop year 2008-2009, smallest is 2,000 and biggest is 18,000 } \\
\text { (Amarra, personal communication, May 17, 2011). }\end{array}$ \\
\hline
\end{tabular}

The mill is situated in the Visayas area, in the north-western part of the Negros Island. It is located on a 45-hectare land and is less than nine kilometres away from the heart of the city. ${ }^{22}$ It is accessible to a seaport that is used for bulk loading of sugar for export or for delivery to other areas in the country. The mill had an estimated milling capacity of 6,200 tons of cane per day until 1992. Its present milling capacity was increased to 7,500 tons of cane per day. Its nearest competitors are two sugar mills which are within a 50-kilometre radius. Considering that swapping of sugar quedans (as discussed in the previous chapter) from different mills are practiced, some of the bulk of raw sugar from the mill is withdrawn and transferred for refining or export; others are bought by industrial users and some are bought for domestic use.

\footnotetext{
${ }^{22}$ The name of the city is also fictitious in keeping with the researcher's ethical obligation to keep the name of the mill confidential.
} 


\subsection{The Impact of Trade Liberalisation}

One of the significant factors that prompted the Azucarero mill to initiate changes was the Philippine government's commitment to the reduction of sugar tariffs in the early 1990s. According to a management representative, the reduction of sugar tariffs has a significant effect on the mills' profitability hence, "the mill has to introduce changes in order to keep up with the growing competition (Anton, personal communication, September 7, 2011)". The next sub-sections report on the strategies undertaken by the Azucarero to address the increasing competition.

\subsubsection{Technological Changes}

Initially, technological changes in the mill consisted of the replacement of old machinery. This was followed by a series of upgrades and improvements in the mill's efficiency. As a local manager explained, in more recent years, the mill has "embarked upon a modernisation and improvement programme to put its facilities into world class condition (Anton, personal communication, November 28, 2011)." Furthermore, according to local management, the modernisation and improvement programme introduced several changes which have consequently affected the structure and nature of work.

For example, in 1997, the mill installed one medium pressure boiler which replaced nine units of semi-manual-operated low pressure boilers. This boiler is fully automatic (controlled by an operator inside an air-conditioned room) and has low maintenance cost. A local manager claimed that the automated feature has resulted in reduced workload, work hours and overtime, which reduced the workforce requirement from 30 to nine workers. The affected workers were reassigned to other jobs. Early retirement compensation with higher separation pay were given as incentive to employees who opt to resign, but resignation is subject to approval by management. Although a mechanical engineer was assigned to every shift, additional training was required to operate it. That required training was provided in-house at the mill's expense. This new technology was introduced to improve both overall efficiency and meet government requirements. It was 
installed as part requirement of the "The Clean Air Act of 1997" because it came with anti-pollution devices.

Another technological change introduced was within the cane preparation process. Before, the mill utilised unigrator which uses fixed hammers that caused more breakdowns. During breakdowns, the hammers need to be replaced immediately so that the mill can continue operating. In 2005, the Azucarero mill shifted from using unigrator to using a shredder. Unlike the fixed hammers, the shredder uses swinging hammers which are more flexible. Consequently, it has fewer breakdowns. Hence, the local manager claimed that this new equipment has also reduced the workload.

Furthermore, in 2009, a boiler economiser was installed at the mill. This increased the maximum continuous rating capacity of the boiler from 200 tons per hour to 224 tons per hour without increasing the furnace loading. It improved steam generation per unit of bagasse fuel thereby reducing bagasse consumption to run the normal operation. Thus, the mill was able to save more bagasse which may be sold or used for other purposes. Unlike the old boiler which required manpower for cleaning, the new boiler has automatic cleaning capabilities. Thus, the impact of this machine also reduced workload.

Finally, in 2011, a new turbo-generator was installed to replace the old units. It has low maintenance and better power to fuel ratio. It allowed the Azucarero to generate excess power. In addition, this new unit has the capability to export power by two to three mega watts to the electrical power grid which can be a potential source of income.

In general, the introduction of technology has increased in recent years. New technology was introduced primarily to improve the efficiency of the mill's operation. However, it was also introduced in part compliance of government requirements on environmental law. The impacts of the introduction of these technologies were the reduction of workload and manpower. The new equipment 
also demanded higher skills which pushed the company to provide additional training to concerned factory workers.

The next sub-section describes how the introduction of technology has affected the structure of work.

\subsubsection{Changes in the Structure of Work and the Conditions of Employment}

The mill then and until now operates 24 hours a day, seven days a week, requiring workers to work additional hours and on weekends. Overtime work is welcomed by a significant number of workers (12 out of the 30 respondents). The Philippine law directs company to pay workers $125 \%$ of their salary for work performed in excess of eight hours (Republic of the Philippines, 1974). Even with that incentive, the premium pay for overtime work granted by the mill is higher than what the Philippine law mandates.

Sugar mills until now compete for sugarcane deliveries. As stated in the previous chapter, the general practice is that sugar mills do not pay for the sugarcane to be delivered by sugar planters. The mills get a share of the sugar produced from it. Thus, the more sugarcane is delivered to a mill, the greater is its revenue. The delivery of sugarcanes until now is partly facilitated by a railway that cuts across neighbouring sugarcane farms and some are delivered by trucks. As with the traditional practice of some mills, the railway had long been constructed by the Azucarero mill within its milling district. This type of hauling of canes cost cheaper compared to the use of delivery trucks leased from independent truck operators. However, with the use of delivery trucks, sugar planters have the ability to choose which sugar mill they will deliver their sugarcane to. Hence, it is imperative that the sugar mill maintains the sugarcane railway in order to gather more sugarcane. To ensure this, the mill used to maintain a pool of workers for its transport and railway services section. 
Including the workers in the transport and railway services section, the mill had a workforce of more than 650 workers until 1996, all of whom were directly employed by the mill. Prior to significant changes that were introduced by the mill in the $1990 s^{23}$ traditionally, a lot of work in the sugar factory involved manual labour which was performed by a pool of workers, referred to as the 'Regular Labour Pool' (RLP). They were considered regular employees of the mill. In keeping with the high demand for manual work, 15 out of $30^{24}$ workers reported that when they started working at the mill, they traditionally spent a significant part of their working time engaged with the careful piling of 50-kilo sugar bags. Other tasks included carpentry, gardening, cleaning the company surroundings and clerical tasks.

During off-milling season, workers from the RLP were re-distributed to complement the workforce of other divisions/departments. Some were assigned to assist semiskilled and skilled workers in the cleaning and repair of factory equipment; others were given clerical tasks. Often, work at the sugar factory extended to more than eight hours per day (during milling season) to ensure that any broken equipment was fixed right away or (during off-milling season) that it was ready for the next milling season. Hence, majority of the workers agree that work before was literally heavily loaded. As one worker noted, "work before was really physically tiring \{ka kapoy gid sang obra sang una\}" (Ernie, personal communication, September 13, 2011). Another worker added that "work was more tiring and demanding before \{mas kapoy kag trabahoso ang obra sg una\}" (Isko, personal communication, September 14, 2011).

The mill's modernisation programme has changed the nature of work at the mill. The piling of sugar bags became partly automated. Conveyors are now used to transport sugar bags and the many sugar pilers were replaced by a few checkers stationed at strategic areas of the conveyor. The checkers work is to see to it that

\footnotetext{
${ }^{23}$ Changes were gradually introduced over the years.

${ }^{24}$ As stated in the methodology, 30 is the total number of respondents representing the workers.
} 
the sugar bags remained aligned on the conveyor especially where the conveyor makes a turn. Thus, the sugar pilers now perform different tasks. A majority of the 30 repondents claimed that their work now involves the use of more cognitive skills such as the trouble shooting and repair of new factory equipment. This is in contrast with the purely physical work they used to perform during sugar piling. Others expressed relief that some areas of the factory can now be conveniently overseen through cameras and operated automatically. Hence, they no longer have to walk back and forth between factory areas. Work is done faster. In addition, a factory worker reported that his/her work formerly revolved around one area of the factory and now another area has been added to his/her responsibility. Management maintained that with automation and the lighter workload, workers can accommodate more tasks.

Workers seemed to approve of the changes. Some of the workers' reactions included:

It is not really that there is more work because work can be done faster and it is lighter now than before. \{Indi man gid nga nagdamu ang obra kay madasig kag mamag-an na ang obra subong sg sa una.\} (Dexter, personal communication, September 13, 2011).

It is okay. Work is almost the same but it is not too tiring \{Ok man lang. Daw amo man gyapon ang obra pero indi na tam an ka kapoy\}

(Santiago, personal communication, September 15, 2011).

It's good. We learned new tasks \{Mayo man. Nakatu-on kami iban nga obra\}

(Akim, personal communication, September 13, 2011).

It seems the same. Some tasks were reduced in here, some tasks were added in there. It's just that it is not too tiring as it was before \{Daw amoamo amo man Ing ah. May iban diri nga obra, may dugang dra. Amo Ing na galing indi gid tam-an ka kapoy sg sa una\}

(Aljo, personal communication, September 13, 2011).

The workers' responses show non-preference to physical work. However, in the change process, overtime was reduced for workers who were no longer assigned at the factory and this was considered by workers as a loss of additional income. 
In effect, technology has made work less physically demanding but now more cognitively demanding. While work can be performed faster, additional tasks were added to some workers. Overtime work has reduced for some resulting in a decreased in income.

\subsubsection{Job Security}

The introduction of technology has drastically reduced employment levels at the mill. With the change from the manual sugar piling to the use of conveyors and the semi-automatic boilers to the fully automated boiler, tasks can now be carried out by fewer workers. As a result, the company gradually abolished the RLP. Other services that were not directly related to the operation of the mill were terminated or merged. These were the air-conditioning, rewinding and auto-diesel sections, and the sanitation and ground maintenance. Furthermore, the management and operation of the transport/railway services was transferred to the sugar planters who formed a cooperative for this purpose. Mill workers in this area of work were 'absorbed' by the new management. Hence, with respect to these workers, there was a change of employer from the mill to the sugar planters. All these resulted in the reduction of the workforce from 667 in 1996 to 350 in 2000 - a reduction of almost $50 \%$ in four years. Presently, the mill maintains an average workforce size of 350. In addition, the Azucarero's workforce is now supplemented with workers from an independent contractor. Some of these contract workers were former workers of the mill performing the same functions such as air condition repair and janitorial services. However, there are differences in benefits between the regular mill worker and that of the contractor. In differentiating it, one mill worker explained...

We all work at the mill. But we regular workers have benefits that they don't have. Like medical benefits, educational loan, housing allowance, and other bonuses given by the mill. ... Because they are not really employees of the mill but of the contractor. \{Parehos man Ing kami naga-obra sa central. Pero kami ya nga regular, may ara sg mga benepisyo nga wala sila. Parehos sg medical benefits, educational loan, housing allowance, kag iban pa nga mga benepisyo nga ginahatag sa central. Kay sila ya indi gid trabahador sg central kon di sg contractor\} 
(Ernie, personal communication, September 13, 2011).

Technological changes have in effect led to jobs such as air conditioning repair and janitorial jobs being outsourced. Hence, some former permanent workers of the mill after retirement from the mill became contractual workers. In effect, it has segmented the mill workers into permanent and contractual. It also means that a portion of the workforce (the contractual workers) is no longer under the direct employ of the mill. Thus, it is evident that the mill has employed numerical flexibility as it may easily reduce the contractual workers compared to the regular workers. Furthermore, it has also created differences when it comes to workers' benefits.

\subsubsection{Skills Training and Hiring Qualifications}

The practice of re-distributing workers from the RLP to other divisions or departments allowed workers to acquire new technical skills. Less than a third of respondents $(n=8)$ claimed that they have acquired knowledge of technical skills such as welding, electronics and repair of factory equipment and vehicles while assisting in the repairs. This was acquired through on the job learning from semiskilled and skilled workers. This implies that the improvement in workers' skills was traditionally a natural result of performing one's tasks.

With the significant reduction of the workforce, the mill was able to continue its operation with a lean manpower because of workers' upgraded competency. As mentioned before, the RLP was abolished and workers therein have been promoted or assigned to different departments depending on their skill qualifications which were initially acquired on the job. In addition to on the job training, the workers also reported that the Azucarero held more training beginning in the 1990s. A representative from the mill reported that company-sponsored skills training were conducted in cooperation with the Technical Education and Skills Development Authority (TESDA). ${ }^{25}$ The company provides for the financial expenses for the

\footnotetext{
${ }^{25}$ TESDA is a Philippine government agency whose mandate is to facilitate the technical education and skills of the country's manpower (TESDA, n.d.).
} 
training while the lecturers/teachers were from the TESDA. Skills trained were generic which included electrical, welding, automotive and diesel mechanic.

A labour union official also revealed that in the process of re-structuring, some union officials, together with a few technical supervisors and managers, were sent to Australia to learn from the operations of more efficient sugar mills overseas. For the mill, management explained that the trip was not only for bench marking but to facilitate a paradigm shift in the perspective of workers . In addition, workers in charge with machinery were sent to product presentations given by domestic and foreign companies. Training was also conducted for the operation and repair of newly installed equipment. All these training were at the mill's expense. The training were conducted with the intent that workers can be given more work. As one mill manager explained:

Multi-skilling was a strategy to enable the lean manpower to do all the jobs.... we have a constant upgrade of machinery and equipment which require new sets of skills ${ }^{26}$

(Ben, personal communication, January 26, 2012).

Twenty three of the 30 respondents revealed that when they started working with the mill, they were assigned unskilled work, specifically sugar piling. Currently 21 of these respondents are now assigned semi-skilled work (i.e. repairs and maintenance of machinery and vehicles). This shows that the nature of work at the mill has shifted from unskilled to semi-skilled work.

In regard to hiring qualifications, with the increase in the workers' skill level, the mill has now elevated its hiring qualification to skilled workers for its factory workers. In differentiating the hiring practices of the mill, some mill worker stated:

Before, even if you don't have enough education, you can still be hired by the central (referring to the sugar mill). Now, you need to have a degree or at least a TESDA certificate. \{Sang una, biskan wala ka mayo tinun-an, pwede ka ma hire sg central. Subong kinanlan college graduate ka ukon may TESDA certificate.\}

(Frank, personal communication, September 14, 2011).

\footnotetext{
${ }^{26}$ No translation included since the manager's reply was in English.
} 
It was easier to join the mill before than nowadays. Now, you already need to know welding or electronics or others. Before, you can learn these when you are already working \{Mas hapos magsulod sa central sang una sg sa subong eh. Subong ya kinanlan kabalo ka na mag welding or may know-how ka sa electronics or kon ano pa. Sang una ya pwede Ing nga matudlu an ka kon naga obra ka na\}

(Manuel, personal communication, September 14, 2011).

It is evident that there was an upward push on employee competency, thus the improvement in workers' skill levels in the latter years has been initiated deliberately by the mill management. This is in contrast to traditional on the job training. Training was conducted to prepare workers to perform more complicated tasks. Some of the skills learned were mostly generic (welding, automotive, electronic). This allowed management to transfer workers from one factory area to another. Hence, with respect to these workers, the company has increased its functional flexibility. However, other skills acquired were more industry specific such as the operation and repair of new factory machinery and equipment. Hence, only these workers have the skills to operate and repair these industry specific machinery and equipment. Thus, with respect to these workers, the company has partly restricted its functional flexibility.

Furthermore, as a consequence of the increased skill competency of the workforce, the company's hiring policy has made preference to skilled workers. This means that unskilled workers have lost their opportunity to be employed at the sugar mill.

\subsubsection{Remuneration}

In terms of remuneration, the sugar mill workers received both wages and benefits (monetary and non-monetary). A manager at the mill revealed that when a worker is hired, part of the stipulations in the employment contract is the regular basic pay that the worker will receive. The amount of daily basic pay/wage is fixed and does not depend on the mill's profit. However, the computation of mandatory benefits such as the $13^{\text {th }}$ month pay and overtime pay is usually a percentage of the basic pay. 
The labour union president claimed that the sugar mill workers receive higher wages compared to the minimum wage (which is considerably higher than the poverty threshold of \$2 per person per day) set by the Regional Wage and Productivity Board (RWPB). ${ }^{27}$ He explained that it has been a practice that the collective bargaining agreement (CBA) between the mill management and the labour union stipulates in advance (generally a period of five years) the yearly percentage salary increases for the workers. The yearly wage increase is a percentage based on the sugar mill workers' basic pay from the preceding year. He added that the minimum wage set by the RWPB is lower compared to what the workers are receiving at the mill. The available data regarding the percentage of yearly salary increases based on the CBA is presented in Table 10. The headline inflation rate is additionally provided to determine the 'real wage increase ${ }^{28}$. The headline inflation rate refers to the fluctuations of the cost of living based on a group of goods that are normally consumed by a Filipino family (The National Statistical Commission Board, 2012b).

Table 10. Increase in Workers' Wage Versus Average Headline Inflation Rate

\begin{tabular}{|c|c|c|}
\hline YEAR & $\begin{array}{c}\text { Percentage Yearly } \\
\text { Salary Increase } \\
\text { Per CBA }\end{array}$ & $\begin{array}{c}\text { Headline } \\
\text { Inflation Rate } \\
\text { Year 2000 as base }\{1\}\end{array}$ \\
\hline 2000 & $5.00 \%$ & No available data \\
\hline 2001 & $4.00 \%$ & No available data \\
\hline 2002 & $4.25 \%$ & No available data \\
\hline 2003 & $4.50 \%$ & No available data \\
\hline 2004 & $5.00 \%$ & $7.20 \%$ \\
\hline 2005 & $4.00 \%$ & $2.00 \%$ \\
\hline 2006 & $4.00 \%$ & $10.40 \%$ \\
\hline 2007 & $5.00 \%$ & $3.90 \%$ \\
\hline 2008 & $3.00 \%$ & $3.70 \%$ \\
\hline 2009 & $5.00 \%$ & $4.00 \%$ \\
\hline 2010 & $5.00 \%$ & \\
\hline 2011 & $4.00 \%$ & \\
\hline$\{1\}$ Figures apply to areas outside the & \\
\hline National Capital Region & \\
\hline
\end{tabular}

\footnotetext{
${ }^{27}$ A tripartite body which prescribes the minimum wage of workers.

${ }^{28}$ Refers to the rate of wages after considering inflation rate.
} 
Source: Data in column two was sourced from the Human Resource Department of the Azucarero sugar mill; Data in column three was taken from the National Statistics Office (National Statistical Commission Board, 2012a).

In relation to the headline inflation rate, considering that the study site is located in Negros which is outside the National Capital Region, the figures that are applicable outside the National Capital Region were used in the table. The table shows that in the years 2005, 2006 and 2008, the headline inflation rates were higher than the salary increases. This means that despite the increase in salary, it is not enought because during those times the costs of goods were higher.

In regard to the benefits received by the sugar mill workers, the mill traditionally provided its workers with benefits which are not granted to workers in other industries. The problem of medical expenses (the state do not provide free hospitalisation nor subsidise medicines) and crowded public hospitals were not a problem to the Azucarero's workers. The mill had its own hospital that catered to the medical needs of its employees despite the presence of private hospitals located about $20 \mathrm{kms}$ from the sugar mill. However, in the early 1980s, the hospital was abandoned. Only a clinic remains with one nurse (with an eight hour duty) and a doctor who reports for a few hours to serve the employees. In lieu of the hospital, the company reimburses the workers and their dependents' medical expenses. However, medicines may be purchased on credit with the guarantee of payment from the mill. Reimbursement is generally in full except the medicines and hospital expenses under the care of specialists such as the eyes, ear, nose and throat specialists, and the cardiogram and CT scan expenses which have a maximum amount for reimbursement in a year. This means that workers now need to provide the initial payment in contrast to a no-cash-out system in the company hospital. Furthermore, traditionally, the policy that parents of workers who are receiving pensions from the government should not be part beneficiary of the workers' medical benefits was overlooked. Now, it is strictly enforced. This implies that the accessibility and the coverage of workers' health benefits have decreased. 
In the old practice, workers were allowed to live within the premises of the company. The mill provided them with free water ${ }^{29}$ and power. In the early 1980 s, the mill increased its operating area for waste and railing bond yard. Consequently, some workers had to relocate their houses far from the company premises. The housing provisions of free power and water were replaced with monthly housing allowances except those who occupy higher ranks in the company who continue to enjoy free housing privileges.

The tradition of granting educational loans to workers is still being practiced. The state does not provide student loans. However, the sugar mill used to pay in advance the full tuition fee of their workers' children (from primary to tertiary) every school year. In turn, these 'cash advances' were deducted in installments from the worker's salary. In recent years, the amount of educational loan has been regulated by the mill management depending on the workers' outstanding obligation.

When it comes to transportation, the Azucarero had at least two company buses which, for a minimal cost, transported the employees and their dependents to and from the neighbouring cities. In the process of restructuring, the mill made an offer to former drivers to form a cooperative to operate the busses independently. Currently, the bus drivers' cooperative continues the bus services charging a minimal rate to workers and their dependents.

In addition to the workers' benefits, a performance bonus scheme has recently been introduced by senior management in the mill. The performance bonus is given by the mill to workers at the end of every crop year. Basically this was initiated to encourage productivity among workers. The mill management established a pointsystem formula for the computation of the bonus which depended on three factors: 1) the mills' profit; 2) the worker's department performance; and 3) the worker's

\footnotetext{
${ }^{29}$ Free water is not provided by the government.
} 
individual performance. This however means that this incentive is partly dependent on factors outside the control of the workers, making it unpredictable.

In summary, driven by cost saving measures, the mill has reduced its commitments to the workers' benefits. Furthermore, it has partly shifted its incentives from nonmonetary to monetary (e.g. free housing provisions such as water and electricity to housing allowance) and non-performance related to performance related bonuses. This has made the total remuneration of workers more variable. On the other hand, although yearly increases in wages of workers covered by the CBA (permanent workers) were found, when the increase of the cost of goods is considered, three years represents no increase in real wages while another three years showed an increase (See Table 10). This signifies a need to link wage increases with inflation rates.

\subsubsection{Health and Safety}

Working at the sugar mill has its health hazards. For example, the sugar mill factory exposed people within the neighbouring area to air pollution. A dark gray smoke emitted from the factory and workers recalled that fine black ash used to reach residences located in the heart of the city. Furthermore, workers claimed that people within the sugar mill compound were prone to inhale very fine ashes and bagasse. Workers reported that in the 1970s, not all factory workers had safety (hard) hats, gloves and masks. Workers sometimes used their clothes to cover their noses. According to one worker, others who were issued gloves and hats by the company did not wear them (Dexter, personal communication, September 14, 2011). Dexter explained that traditionally, workers did not feel comfortable wearing hard hats. They found it inconvenient to wear gloves because it slows down their work (they have an accurate grip with their bare hands). He further stated that workers assigned in the laboratory were exposed to chemicals. A few accidents had happened to those dealing with machinery. He added that workers then had little awareness of the long term danger of being exposed to chemicals or took serious consideration of the consequences of accidents. All they cared was having a job. As 
a mill worker expressed, "the risk is already part of the job. What is important is you have a job \{daw parte na na guro sg obra ang risgo. Ang importante may obra\}" (Dexter, personal communication, September 14, 2011). In addition, another worker stated that "in any work, there is always some risks \{biskan diin nga obra may ara man gid risgo ah\}" (John, personal communication, September 14, 2011). It appears that workers traditionally trade health and safety issues for employment.

In recent years, the mill has improved its health and safety programme. Hard hats, gloves and masks are now available for employees working in the factory and even for other employees and visitors who enter the sugar factory. Safety procedures for operating machines and equipment are posted at strategic areas in the factory. A mill representative claimed that labour inspectors have expressed that the mill more than adequately meets the health, safety and environmental requirements mandated by Philippine laws (health, safety and welfare requirements set by the Labour Code and the Department of Labour). The mill representative also stated that the Department of Labour and Employment has actively campaigned for a "Zero Accident Programme" and the mill has made it as part of its corporate social responsibility agenda. Seminars on safety were conducted among workers, making them fully aware of the necessity of following safety procedures. Furthermore, safety was introduced as part of the performance-related bonus. As a mill manager explained, the "department with lesser accidents has more points on safety. These points are translated into monetary values (Ben, personal communication, January 26, 2012)"

As a consequence, workers are now diligently abiding by the mill's health and safety procedures. The worker's representatives are actively involved in an 'employee safety committee' initiated by the management. It regularly convenes to review the safety policies and procedures of the Azucarero and facilitates its strict implementation.

A majority of the respondents believed that being more informed about the risks in their work and the consequences of not following the safety procedures plus the 
company's strict implementation of the rules resulted in a change in the attitude of workers with regard to safety measures. Furthermore, the consequence of accidents to their performance bonus also made them more cautious. Thus, if before workers traded safety for employment, now, an increase in performance bonus has become an incentive to their safety.

In addition, the new boiler has changed the smoke emission of the factory from black into white smoke which is more health and environmentally friendly. It is compliant to environmental laws. Furthermore, a worker stated that commercial buyers of sugar such as cola companies have in recent years, inspected factory premises to check whether the mill observes satisfactory safety and sanitary procedures.

In general, four factors can be pointed out which led to the Azucarero's improved workers' safety programme, namely: 1) government laws; 2) buyer requirements; 3) workers' better understanding of the implications of safety measures to their health and safety and; 4) their performance bonus.

\subsubsection{Product and Inter-sectoral Upgrading}

Another economic upgrading strategy of the mill was product upgrading. In 1986, the Azucarero mill established a process to produce 'blanco directo', a plantation crystalline white sugar which has a substantial premium in comparison to raw sugar prices. More recently, the mill has begun producing muscovado. ${ }^{30}$ This sugar commands a much higher price than the raw, blanco directo and refined sugar. However, muscovado production is not considered by the management as a major economic venture. A mill representative reported that while there is a viable market for organic muscovado (to be considered organic, this means that no chemicals were used from the start of production which includes the soil), a lot of chemicals have already been introduced to sugar lands making it unfit for organic

\footnotetext{
${ }^{30}$ Muscovado is an unrefined sugar which, because it is less processed, retains all cane sugar nutrients and is considered to have more health benefits than raw or refined sugar.
} 
production. Moreover, the land needs to rest for several years before it will become chemical free. Thus, the mill is only producing muscovado in limited quantities.

A local manager added that the production processes of blanco directo and muscovado have a slight difference compared to raw sugar production. Hence, these have not significantly affected manpower requirements or the nature of work. This revealed an example where economic upgrading in the form of product upgrading has no significant impact on decent work.

Inter-sectoral upgrading in the form of diversification is another economic upgrading strategy being envisioned by the mill. As earlier stated (Section 5.2 D and E), the mill has saved on bagasse because of the installation of the boiler economiser and turbo generator. As an additional source of revenue, the mill sells its excess bagasse. Lately however, the excess bagasse is contemplated for energy generation. Currently, the company has excess electricity sourced from bagasse and commercial sale of this excess power is now seriously being considered. If this plan pushed through, the local manager foresees that there will still be no significant increase in personnel.

In short, the Azucarero employed product and intersectoral upgrading strategies. It produced 'blanco directo' and 'muscovado' sugars which both have higher values than the raw sugar that mills traditionally produced. Moreover, the Azucarero also plans to diversify by utilising its excess bagasse for power generation, instead of merely selling it to other mills. All these increased the Azucarero's financial resources and revenue, making it more competitive. However, these do not result in substantial changes on employment generation or the quality of employment.

To sum up, permanent workers at the mill were significantly reduced while a few contractual workers were hired (numerical flexibility). Work at the mill has shifted from physical to cognitive. Skills training has changed from on the job to formal 
training because of the upward pressure on workers' skills in pursuit of functional flexibility. Consequently, manpower entry requirements have also changed as a result of recent changes. It has limited the job opportunity of unskilled workers at sugar factory. In relation to remuneration, yearly increases in workers' wages were stipulated in the collective bargaining agreement but did not reflect inflation rates. There was also a reduction in non-monetary benefits. On the other hand, a performance bonus was introduced which made the determination of remuneration more variable. Additionally, the mill has improved their health and safety programmes which were partly caused by government laws and buyerrequirements.

\subsection{Summary of Key Findings}

To summarise, the findings in the case study show that tighter competition, both internationally and domestically, led the Azucarero sugar mill to introduce cost competitive changes. Mainly, these were the introduction of new technology and by moving up in the value added chain through the production of blanco directo and muscovado. In addition, it plans to diversify by selling its excess power generated.

One of the significant impacts of trade libaralisation on the mill was numerical flexibility as evident by a significant reduction in permanent workers while resorting to sub-contracting. The introduction of advanced technology was the major driver in the change of the structure of work at the mill. Work at the mill has shifted from physical to cognitive. Skills training has changed from on the job to formal training because of the upward pressure on workers' skills in pursuit of functional flexibility so that the mill can operate with leaner manpower. Consequently, skill requirements for job seekers have increased. In relation to remuneration, yearly increases in workers' wages were stipulated in the CBA every five years hence, did not reflect changes in inflation rates. There was also a reduction in non-monetary benefits. On the other hand, a performance bonus was introduced which made the 
determination of remuneration more variable. The mill has improved their health and safety programmes which were partly caused by government laws and buyerrequirements. In general, the overall-perception of workers is that their work conditions have improved as a result of these changes.

The next chapter will discuss and analyse the changes in the work conditions of the workers in relation to the developments in the sugar industry reported in Chapter Four and the literature cited in Chapter Two. 


\section{CHAPTER SIX \\ Discussion and Analysis}

\subsection{Introduction}

This chapter revisits the aim of this research which is to explore the impact of trade liberalisation on decent work among the sugar mill workers in the Philippines. It does so with a view to identify this study's contributions to existing trade liberalisation and decent work literature. This chapter discusses and analyses the findings in relation to the literature reviewed. The chapter is structured according to the four aspects of decent work and in the process addresses the research question - How has trade liberalisation impacted on decent work among the sugar mill workers in the Philippines?

\subsection{The Impact of Trade Liberalisation on Decent Work}

As illustrated in Figure 12, decent work has four aspects: 1) job generation and the quality of employment, 2) rights at work, 3) social protection and 4) social dialogue (ILO, 2012b). 
Figure 12. Developed Theoretical Framework

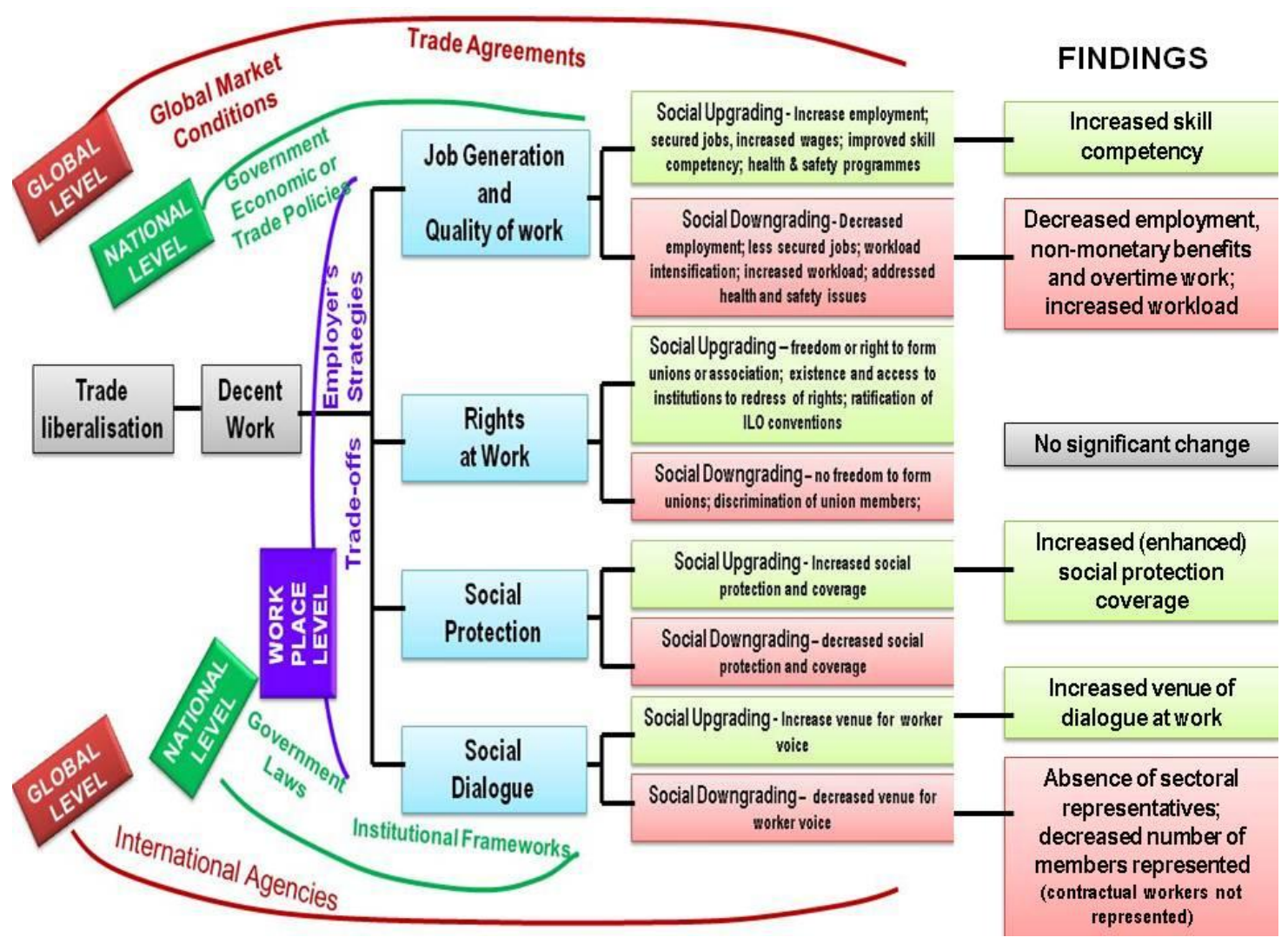

\subsubsection{Job Generation and Quality of Employment}

As previously outlined, according to the ILO, one of the primary objectives of decent work is job creations and an improvement in the quality of employment (ILO, 2012b). The next subsections examine the indicators of this objective as identified in the literature (Anker, Chernyshev, Egger, Merhran \& Ritter, 2003; Bonnet, Figueiredo \& Standing, 2003; Ghai, 2003).

\section{Employment/Unemployment}

This study provides contrary evidence on the employment generation theory advanced by trade liberalisation proponents as reported by Kelly and Prokhovnik (1996). This study found that employment levels in the mill dropped by almost 50\%.

It was largely a result of labour-saving technology and outsourcing (contractualisation) in response to the growing competition due to the decreasing sugar tariffs. The sugar industry is a protected industry in the Philippines because its 
cost of production cannot compete with other more cost-efficient sugar producing countries. Thus, this result is consistent with several studies conducted in protected (less cost-efficient) industries in developing countries which also found a decrease in employment as a result of tighter competition brought by trade liberalisation (SAPRIN, n.d.; Serrano, 1997; Revenga, 1995). While the Solidar (2007b, 2007c; 2007d; 2007e) case studies have commonly shown an increase in employment levels, this study does not entirely contradict the Solidar findings since the industries examined by Solidar were export-oriented industries. Thus, there is strong indication that the employment generation theory of trade liberalisation only applies to export-oriented industries and not to protected industries. This supports the World Commission on the Social Dimension of Globalisation (2007) claim that trade liberalisation produces uneven results among industries.

This study further supports the theory that export is relative to employment demand. When the mill started reducing its manpower from 667 in 1996 to 350 in 2000, the percentage of sugar production exported to the US (the Philippines' major export market), was in the decline (12.8\% in crop year $1995-1996$ to $4.95 \%$ in crop year 2000-2001 as reported in Appendix M). The decrease in export coupled with a decrease in employment is reversely analogous to some research (Orbeta, 2002; Bhalotra, 2003; Cling et al., 2009) which found an increase in aggregate employment as a result of increase in export. Thus, indicating a strong relationship between export and employment demand.

\section{Wages}

In general, in this study, the impact of trade liberalisation on wages remains unclear. This is because this study found an increase in real wages in three years (2007, 2009 and 2010) and a decrease in real wages in another three years (2005, 2006 and 2008). The different impacts on wages are consistent with the different results in existing literature. Some literature reports that trade liberalisation leads to increased wages (Bernhardt \& Milberg, 2011; Bhalotra, 2003; Revenga, 1995) while others reported reduced real wages (SAPRIN, n.d; Serrano, 1997) or it has no significant effect (Feliciano, 2001). Thus, it invites future research to determine the 
factors that influence the impact of trade liberalisation on wages. Furthermore, what is commonly evident is that although wage increases were seen, there is still greater focus on profitability and productivity.

In relation to wages, this study emphasises the importance of taking account of inflation rates. As the findings reveal, although wage increases were provided in the collective bargaining agreement, in the years 2005, 2006 and 2008 (three years out of six years or $50 \%$ of the available headline inflation rate data), the headline inflation rates (increase in the cost of goods) were higher than the percentage of wage increases. This follows the interpretation and affirms the finding of Solidar (2007c) in the textile industry in Cambodia that although wages were increased, it was not enough to cover the increase in the cost of goods. Hence, in such instances, despite the wage increase, there was actually a reduction in the value of wages. The decrease in the value of wages can be partly attributed to the fact that wage increases are based on CBA stipulated three to five years in advance and hence do not take into account future inflation rates. Thus, this study directs the attention of union representatives towards the alignment of the provisions of workers' wage increases in the CBA with inflation rates.

\section{Benefits}

This study highlights the relevance of examining workers benefits in the discussion of cost-cutting measures. This study supports claims that indicate the likelihood of reduced workers' benefits when the industry opens up more fully to international competition (Robertson, Sitalaksmi, Ismalina \& Fitrady, 2009). Hence, evaluating wages alone as most research studies have (Bhalotra, 2002; Feliciano, 2001; Hunt et al., 2007), including those conducted in the Philippines (Orbeta, 2002; SAPRIN, n.d.; Serrano, 2007), is a narrow way of determining the value of workers' remuneration in relation to the decent work agenda. This is in view of Mugisha (2003) and Rudman's (1999) defining remuneration to include not only (monetary) pay but also non-monetary benefits. This research clearly shows that there has been a reduction in worker benefits. These include: the refund of medical expenses whereas traditionally, free services were offered by the company hospital (which stopped 
operation); reductions in the coverage of medical refunds (limiting the amount of refund on special treatments and excluding parents with pensions from the medical coverage); and the provision of fixed amount of housing allowance instead of free housing provisions (unlimited use of electricity and water). The reduction of these non-performance-related benefits coupled with the introduction of the performance bonus suggests a shift in granting benefits towards performancerelated pay. However, the inclusion of these (monetary and non-monetary) benefits in determining remuneration under the decent work agenda will increase the difficulty in making cross-industry comparison of wages as the grant of these benefits may differ between industries and even among establishments. Furthermore, this will create a need to develop a standard in determining the value of non-monetary benefits.

The findings on remuneration have also provided an instance that disproves the argument of Ranney and Naiman (1997) who stated that profits from trade liberalisation do not automatically ripple down to workers' benefits. The introduction of the performance incentive bonus where the amount is partly contingent on the mill's profits has established a direct relationship between profitability and wages. Thus, this part of the findings supports the positive view of trade liberalisation that the benefits from free trade will result in an increase in the level of income (American Foreign Policy Association, 2002).

\section{Job Security}

This study affirms literature which suggests that increasingly, employers seek greater numerical flexibility in response to trade liberalisation. Several studies have found that employers prefer hiring contractual (Robertson Sitalaksmi, Ismalina \& Fitrady, 2009; SAPRIN, n.d) and casual workers (Bhalotra, 2002; Hunt et al., 2007; Solidar, 2007b). In this study, the reduction of permanent workers coupled with the employment of contractual workers (subcontracting) in the mill is, as explained by Roca-Puig et al. (2008), also an evidence of a shift towards numerical flexibility. 
The implication of contractualisation in the sugar mill is that some jobs are becoming less secure. Although the mill was able to retain the services of the contractual workers (also former mill workers), the obligations of an employer have been passed on to the contractor. There is no employer-employee relationship between the mill and the workers of the contractor. Considering the Philippine Labour Code provisions apply only when there is an employer-employee relationship (Republic of the Philippines, 1974), the services of the contractual workers are dependent upon the contract between the mill and the contractor. Furthermore, because of the absence of an employer-employee relationship, neither termination nor separation benefits may be demanded from the mill unlike with permanent mill workers. Thus, trade liberalisation has resulted in less secured jobs to some (former) sugar mill workers (contractual workers). The challenge is therefore for government to expand the protection coverage of law to more vulnerable workers such as the contractual workers.

\section{Health and Safety}

According to the ILO (2006), buyer requirement proves to be an effective way of promoting decent work. This research adds to that literature where better working conditions were introduced in compliance with buyer requirements. In this research, multi-national companies that commercially use sugar require that the sugar factory maintain some sanitary and safety standards. Furthermore, the government launched the Zero-Accident Programme. These have encouraged the mill to create an employee safety committee which ensures the strict implementation of the mill's health and safety programme. Considering that buyer and government requirements prove to be an effective way of promoting beter work conditions, promoters of decent work is therefore invited to rally both government and the civil society (consumers) in demanding from producers that products are produced under decent work conditions.

\section{Work Hours}

Empirical research suggests that work hours were lengthened without substantial increase in pay as a way to reduce cost (Solidar, 2007c). This means there was work 
intensification and hence a form of social downgrading. This study affirms that trade liberalisation results in social downgrading in relation to work hours. However, instead of lengthened work hours, overtime work (work beyond eight hours per day) for some workers was reduced (due to automated machines). This was also a form of cost reduction because the mill has to pay $125 \%$ of the worker's basic salary (Republic of the Philippines, 1974) for every hour of work done beyond eight hours per day. This implies a reduction in 'take home' pay. Thus, the drive towards cost efficiency as a result of trade liberalisation can lead to either an increase or decrease in work hours. However, what is constant is the emphasis on cost reduction.

\section{Skills, Training and Workload}

This study indicates that trade liberalisation in the Philippines reduces employment opportunities for unskilled workers. As the findings reported, there was a shift of employment demand towards more skilled workers. In pursuing economic upgrading, the mill was compelled to train its workers to keep up with advanced technologies. This also resulted in the mill's hiring preference moving to skilled workers. This supports the study of Lim and Bautista (2002) also conducted in the Philippines which found a swing in employment opportunities in favour of skilled workers. In addition, Solidar (2007e) also reported a demand for call centre agents (English speaking skills) in the Philippines. Thus, the continued trend of declining demand for unskilled workers creates an added challenge for employment generation in the Philippines in terms of improving the skills of its workforce.

The study also reveals that trade liberalisation can push firms towards functional flexibility leading to skill upgrades for workers. However, the downside may be work intensification. As revealed in the findings, workers' competency needed to improve to enable workers to multi-tasks, consistent with the mill's cost-efficiency measures. This is in line with the strategy on functional flexibility (Roca-Puig et al., 2008). However it indicates a trade-off between improvement in workers' competency and workload. Although the reviewed literature has signified that there can be trade-offs between indicators of decent work, the trade-offs 
discovered were by large, in favour of retaining employment as against freedom of association and absence of workers' voice (Solidar, 2007b; 2007c; 2007d), or issues on health and safety (Solidar, 2007c; 2007e). As such, these trade-offs all result in social downgrading. Thus, adding to literature on trade-offs among decent work indicators, this research has found that trade-offs could also exist between indicators of social upgrading in the form of improved skills and social downgrading in the form of workload intensification.

In relation to the human resource (HR) practices of employers, it is observed that the change in the HR practices of the mill follows that of the ISI sector which is slowly shifting towards following the practices of EOI sectors (Skene, 2003). This can be partly attributed to the fact like the ISI sector, that the lowering of sugar tariffs makes the mill vulnerable to cheaper sugar imports. Hence, there is also greater numerical flexibility through layoffs and contracting, emphasis on training and skill upgrading, some efforts on functional flexibility and linking payment to performance (through the performance bonus).

In summary, in relation to job generation and the quality of employment, the discussion and analysis point out that trade liberalisation has resulted in the change of the mill's HR practices, specifically the reduction of employment, non-monetary benefits and (to some workers) work hours and an increase in workload. These all reflect social downgrading. On the other hand, social upgrading is evident in terms of increased employee competency. Lastly, the effect of trade liberalisation on wages remains undetermined.

\subsubsection{Rights at Work}

\section{Freedom of Association and the Right to Form Labour Union}

Rights at work may be evident when workers are given the freedom of association or to form unions (Anker, Chernyshev, Egger, Merhran \& Ritter, 2003; Bonnet, Figueiredo \& Standing, 2003). According to Ghai (2003), the issue is whether these rights are respected. 
This study shows that the key to ensuring that workers are provided rights at work through legislation and ratification of ILO conventions is its effective implementation. Various countries ratified ILO Conventions regarding the freedom of association and protection of workers' right to organise (Solidar, 2007b; 2007c). Others grant the right to form labour unions as a constitutional freedom (Cling et al., 2009). Yet, studies in these countries revealed that union membership is damaging to their employment (Solidar, 2007b; 2007c; Cling et al., 2009). The Philippines likewise have granted the workers with the constitutional freedom to form unions (Republic of the Philippines, 1987). The government's policy regarding these rights is further strengthened by the ratification of ILO conventions governing these matters. Further, the grant to these rights are reiterated in the Philippine Labor Code (Republic of the Philippines, 1974) which further provides procedures for union certification, strikes, lock-outs and redress of grievances. In addition, the implementation of the rights at work is facilitated by the fact that the labour union officials have a general knowledge of labour laws and they have regular legal counsel advice from their affiliated union federation. Thus, the right to form union free from discrimination has always been practiced at the mill. This substantiates results from Solidar's (2007c) study that the continued enjoyment of the rights at work are ensured by workers' knowledge of their rights and the existence of procedures to enforce their rights. This means that laws and ratification of the ILO convention pave the way for decent work. Hence, there is basis for research claims that laws and ratifications of ILO conventions promote decent (Theron et al., 2007). However implementation is an important aspect in ensuring its efficacy.

One major hindrance in providing decent work through legislation is the absence of a body that ensures its implementation. In addition to the cases of violation of workers' rights cited above, the Philippines has also overlooked the implementation of one significant law in relation to workers. The Social Amelioration Law (SAL) (Republic of the Philippines, 1991) sets aside a fund to be distributed to sugar workers to supplement their income. However, the findings reveal that more than US\$1.23 million remains undistributed as of the Fourth Quarterly Report of the Bureau of Labour Relations (2010). Although this law does not necessarily fall within 
the aspect of rights at work as defined in this research, it is nevertheless drawn on here to highlight the need for promoters of decent work to direct their focus on ensuring that these laws or agreements are implemented.

Thus, in relation to workers' rights, the right to freedom of association of sugar mill workers and to form labour unions had been enshrined by law and trade liberalisation has not caused a significant change. However, the imposition of their right to better work conditions is partly hindered by ineffective implementation of some laws such as the SAL.

\subsubsection{Social Protection}

Social protection as an aspect of decent work is measured in this study by the existence and coverage of social or employment protection as suggested by other researchers (Anker, Chernyshev, Egger, Merhran \& Ritter, 2003; Bonnet, Figueiredo \& Standing, 2003; Ghai, 2003).

In relation to social protection, again, labour laws have facilitated decent work. In the Philippines, employers are mandated to contribute equally with the workers to the Social Security System (SSS) to cover the social protection of workers in the amount specified in the schedule of payment provided by the SSS (Republic of the Philippines, 1997). Thus, sugar mill workers or their beneficiaries have a social security provident fund where they or their beneficiaries can obtain financial assistance in cases of retirement, disability, pregnancy, sickness and even death. This law has been in place since 1954 and amendments to the law in 1997 have increased its benefits in light of inflation and have extended the coverage to selfemployed individuals. Hence, as long as a worker is employed, the worker's employer contributes $50 \%$ for the worker's social protection coverage premiums. Thus, we can say that trade liberalisation generally has minimal effect on the social protection of workers in this respect.

However, in addition to legislation, this research also suggests to consider industry social programmes as another indicator of social protection. It is recalled that the 
sugar industry has social programmes provided by the sugar producers for the sugar workers. The programmes which include livelihood and generic skills trainings provide mill workers an alternative income and increase their chances for employment in case of job loss or retirement. However, the programme is funded from voluntary contributions of the employers. Thus, another challenge for the decent work agenda is the promotion of social responsibility among employers with respect to their workers.

Hence, trade liberalisation through the strengthening of laws and industry social programmes have enhanced the social protection coverage of sugar mill workers an evidence of social upgrading.

\subsubsection{Social Dialogue}

Social dialogue refers to the consultations and negotiations that exist between labour, employer and management (Kuruvilla, 2006). This research found that social dialogue is largely available through a number of avenues. At the workplace level these include the collective bargaining and the employee-safety committee and the labour party-list representative in Congress at the national level.

In this study, social dialogue was both enhanced and hindered by institutional frameworks. At the national level, enhancement of social dialogue is illustrated in the Philippine legislative framework where representatives from the labour sector may run as party-list representatives in Congress. The 1987 Philippine Constitution (Republic of the Philippines, 1987) provides a venue where workers can be represented in the national legislative process. However, this same framework also hinders the promotion of sectoral dialogue. The process of electing congressional labour representatives discourages sectoral representation in order to gather more votes. This results in a weak sectoral representatives at the national level. Consequently, dialogues at the national level seldom focus on (sugar) industryspecific issues. Furthermore, the fragmented union structure (with ten trade union centres covering 113 union federation or national federation with each union 
federation having at least 10 local unions) at the national level also diminishes workers' bargaining power.

However, venues for workers' voice may also be limited by beliefs that workers participation is only required in labour issues. As the findings of this research report, government introduced employer participation in the Sugar Board at the Sugar Regulatory Administration (an agency created in part due to trade liberalisation) (Republic of the Philippines, 1986). However, it has disregarded worker representation despite the government's thrust for tripartism. One possible explanation is that the agency's main mandate is to ensure the survival of the sugar industry under fair conditions to consumers. Apparently, this does not concern the workers. Thus, there could be an erroneous belief that the workers' participation is not necessary in economic policy formulation. This diminishes worker's voice as social dialogue covers all types of negotiations at all levels relating to both social and economic policies, among others (Kuruvilla, 2006).

Furthermore, this research suggests that labour unions are limited in their ability to represent the voice of all workers at the workplace level. The limitation is demonstrated in the findings revealing that enterprise-based labour unions compete in a certification election to be the exclusive bargaining agent for all the permanent workers. This can create division among workers hence, impeding effective worker representation. Thus, this study emphasises Ghai's (2003) challenge of finding a representative that will effectively represent all the workers.

Furthermore, trade liberalisation has deprived part of the workforce of their voice at the workplace level. This is true with respect to contractual workers whose employee status changed (from permanent workers) due to the numerical flexibility employed by the mill. While Philippine law (Republic of the Philippines, 1974) has mandated employers to bargain with labour unions, contractual workers are not members of the union nor do they benefit from the union's negotiations. Being employees of an independent contractor, it is their employer, the contractor, who negotiates with the mill management. Thus, the segmentation of workers to 
permanent and contractual has reduced union membership, thereby diminishing worker voice.

In relation to worker voice, buyer-requirements have triggered an increase in workers' participation. The findings of this research reveal that buyers have required a standard of safety and sanitation at the factory. To enhance the mill's safety programme, the management created an employee-safety committee which is composed of management and workers' representatives. Thus, it is an added worker dialogue venue.

In summary with regard to social dialogue, trade liberalisation has led to more social downgrading than upgrading. Social upgrading was facilitated through buyerrequirements which increased the permanent workers' participation in health and safety issues at work. However, more downgrading indicators were seen such as the deprivation of contractual workers of voice at work (in CBA negotiations) and absence of sectoral representation both in Congress and in the SRA.

\subsection{Factors That Shape Decent Work}

To sum, trade liberalisation in this study, is facilitated at the global level by exports (global market conditions) and ILO conventions (international agencies) which have partly shaped decent work. However, the sugar tariff reduction (from 50\% in 1986 to the initial commitment of $5 \%$ in 2010), has the most influence on decent work. It has triggered the mill to initiate new strategies in order to counter the growing competition, both in the local and international market. These strategies, as discussed earlier have affected decent work. This finding is comparable to the textile industry in Indonesia. Changes in employment and work structure have been observed during the termination of the multi-fibre agreement which gives preference to its Indonesian producers (Solidar, 2007c). This supports the argument of Frenkel and Kuruvilla's (2002) that the degree of the firm's exposure to free trade determines employment strategies. 
Relevant to the investigation of decent work are the factors that shape it. The discussions in the earlier sections highlight the factors that have shaped decent work at the sugar mill. These factors, are employer strategies (through economic upgrading), labour and environment (new indicator) laws and institutional frameworks (additional factor) (see Figure 13).

\subsubsection{Economic upgrading}

Economic upgrading, as an employer strategy, has been found to be an effective response to tighter competition brought on by trade liberalisation. The mill resorted to three methods of economic upgrading as identified in the literature (Humphrey \& Schmitz, 2002). These are 'process upgrading' through the introduction of technology, 'product upgrading' through the production of muscovado and blanco directo sugars and 'inter-sectoral' upgrading through commercial power generation. As a result of this economic upgrading, the mill was able to save on costs by using labour-saving technology and increase its revenue from higher valued products. This supports Held's (2004) argument that trade liberalisation compels firms to become efficient and thus affirms the cost-efficiency theory of pro-trade liberalisation (Ghai, 2003). However, the drive for costefficiency through the introduction of advanced technologies, as earlier discussed, has resulted in a major revamp in employment demand, work hours, workers' competency (skills training) and workload.

\subsubsection{Segmentation of Workers and Numerical Flexibility}

Another employer strategy which the discussion has stressed is the use of numerical flexibility. This was in terms of employing contractual workers in lieu of permanent workers. The employer's strategy of segmenting workers to permanent and contractual resulted in greater inequality in decent work among workers. The findings indicate that the segmentation of workers has reduced some former mill workers' (contractual) wages and benefits, made their job less secure and diminished their employee voice. Hence, the use of numerical flexibility refutes the 'reduction of inequality' theory of trade liberalisation advanced by its proponents 
as reported by Periera (2010). On the other hand, it expands Safa's (2002) theory that trade liberalisation creates inequality (between labour and capital) within nations by providing evidence that inequality is also created among workers. Thus, this study strengthens Ghai's (2003) argument that the impact of trade liberalisation may depend upon the type of worker or the nature of work.

\subsubsection{Laws}

Existing laws also determine employers' strategies. The employment of contractual workers is also an employer's way of getting part of their workforce out of the employment-income protective nature of existing laws as these exist for permanent workers. This substantiates Frenkel and Kuruvilla's (2002) theory that employment strategies are affected by the intensity of exposure of the industry to global competition and government laws. As the findings of this study record, the Philippine Labour Code (Republic of the Philippines, 1974) is more protective of permanent workers. Thus, the mill could get away with providing lesser benefits to contractual workers (e.g. separation pay, contribution for social coverage). The challenge therefore in relation to decent work is for government to include under the laws' protection the more vulnerable workers such as contractual workers.

Further, other than labour laws, non-labour laws can also advance decent work. Although existing research has mainly examined labour-related laws in relation to decent work (Cling et al., 2009; Solidar, 2007b; Quijada, 1979; Wood et al., 2004), this study has provided evidence that decent work can also be promoted in nonlabour laws. In this study, when the sugar mill introduced the new boiler to reduce factory smoke emissions in compliance with The Clean Air Act of 1997, it also improved the health of workers.

However, it is equally relevant to note that the improvement in the health of workers was easily facilitated through technology that serves both the interest of the employer and the worker. This is because the findings also note that the primary purpose for the installation of the new boiler was to improve the mill's 
efficiency. Hence, the availability of technology that can both improved efficiency and promote better work conditions becomes important in striving for decent work.

\subsubsection{Institutional Frameworks}

These findings in relation to institutional frameworks highlight Kelly's (2001) argument that workers have active roles to play in improving their own working conditions. As discussed in the social dialogue section, generally, existing institutional frameworks (fragmented labour unions and no sectoral representation at the national level) have diminished worker voice. Thus, the advancement of decent work in the Philippines creates a need for a united labour union that will tear down the frameworks that hinders the promotion of decent work.

\subsection{Trade-Offs Between and Amongst Indicators and Aspects of Decent Work}

As cited in the literature review, it is important to investigate the relationships between indicators of decent work. This is equally relevant in this study as trade liberalisation is creating a pattern showing that workers are trading the quality of their employment or some rights at work for job retention. Trade-offs between and among the different indicators and aspects of decent work can be implied from the earlier discussions on the impact of trade liberalisation. These trade-offs echo the findings of other research studies showing trade-offs between the quality of employment, rights at work and social dialogue on the one hand and employment on the other hand (Solidar, 2007c; 2007d; 2007e). Table 11 summarises and compares the trade-offs in existing literature and this study. 
Table 11. Trade-offs Between and Among Aspects of Decent Work

\begin{tabular}{|c|c|c|c|}
\hline & \multicolumn{3}{|c|}{ In favour of } \\
\hline Aspects/Indicators of Decent Work & \multicolumn{2}{|c|}{$\begin{array}{c}\text { Employment } \\
\text { (Solidar cases) Existing Trade-offs }\end{array}$} & New Trade-offs \\
\hline \multicolumn{4}{|l|}{ Employment \& Quality of Employment } \\
\hline Decrease in wages & 2007b; 2007c; 2007d & \multirow{2}{*}{$\begin{array}{l}\text { affirmed } \\
\text { affirmed }\end{array}$} & \\
\hline Lesser job security & $2007 b$ & & \\
\hline Health \& safety issues & 2007c; 2007e & not applicable & \\
\hline Non-monetary benefits & & & $\begin{array}{l}\text { monetary } \\
\text { benefits }\end{array}$ \\
\hline $\begin{array}{l}\text { Increased work hours } \\
\text { Workload intensification }\end{array}$ & & & $\begin{array}{l}\text { Increased pay } \\
\text { skill } \\
\text { competency } \\
\end{array}$ \\
\hline \multicolumn{4}{|l|}{ Rights at Work } \\
\hline Freedom of association & $2007 b ; 2007 c ; 2007 d$ & not applicable & \\
\hline \multicolumn{4}{|l|}{ Social Dialogue } \\
\hline Venue for dialogue & 2007b; 2007c; 2007d & affirmed & \\
\hline \multicolumn{4}{|l|}{ Legend: } \\
\hline \multicolumn{4}{|c|}{ Green - refers to trade-offs found by existing literature and affirmed by this study } \\
\hline \multicolumn{4}{|c|}{ Yellow - refers to trade-offs found in literature but not found in this study } \\
\hline
\end{tabular}

The table shows that this study has affirmed trade-offs found in existing literature (marked in green boxes) namely, decrease in wages, lesser job security and venue for social dialogue in exchange for employment on the part of the contractual workers. However, the trade-off in the freedom of association in lieu of employment established in the literature reviewed does not apply to this study (marked in yellow).

On the other hand, as a contribution to the literature on the impact of trade liberalisation, this study discovers three new trade-offs (marked in red boxes) which the literature reviewed thus far, has not established. First, is the trade-off between the reduction of non-monetary benefits and the introduction of new monetary benefits (performance bonus). Second, for some workers, there was a trade-off of more work hours (overtime work) for increase in pay. Third, is the trade-off between increased skill competencies and workload intensification. 
Generally, these indicate that workers are trading the quality of employment to remain being employed. This strengthens Ghai's (2003) challenge to create jobs coupled with quality employment.

In summary, the varied impact of trade liberalisation shows its multi-effect on the different aspects of decent work. Its impact is influenced by several factors at global, national and workplace levels. Furthermore, the kind of worker (permanent or contractual) and the level of negotiations (national or workplace level) has greatly shape impacted on decent work.

The next chapter will provide a brief summary of the key points made in this chapter and the conclusion to this research study. 


\section{CHAPTER SEVEN \\ CONCLUSION AND IMPLICATIONS}

\subsection{Introduction}

The purpose of this chapter is to summarise and highlight the key findings of this study. It enumerates the contributions of this study and concludes by identifying the research implications and future research agenda, the policy implications and the limitations of these findings. Lastly, the researcher leaves her personal thoughts in the concluding remarks.

\subsection{Summary of Key Findings}

In summary, this study suggests that in protected industries, decent work will be negatively affected by trade liberalisation. Consistent with the positive view of trade liberalisation, it has compelled the mill to become cost effective. However, the drive for cost-effectiveness has resulted in greater social costs than benefits which are borne primarily by the workers (in terms of declining decent work). For the Phillipinne sugar industry, trade liberalisation has mainly taken the form of a reduction of sugar tariffs. This increase in competition prompted the mill to initiate changes in their manufacturing processes and employment strategies. The outcome of which resulted in both the social upgrading (improvement) and the downgrading (decline) of decent work. Improvement in the aspect of job generation and the quality of work was found among existing sugar mill workers. This is indicated by the increased level of skills among workers and improved safety programmes. At the same time, there is a decline of decent work in terms of reduction of workers. This discredits the employment generation theory of trade liberalisation. Furthermore, work intensification and a reduction of workers' benefits were also evident. With respect to remuneration, the finding is not conclusive. There were years when there were increases in real wages and there were years when the increases in nominal wages were not enough to cover the increase in headline 
inflation rate. It was discovered that the determination of remuneration of workers has become dependent on several factors other than the workers' performance. These include team productivity and company profitability. In relation to worker rights, while sugar mill workers were found to enjoy the right to organise and bargain, these were mainly a result of law rather than of trade liberalisation. Hence, it has not created a significant change. In the aspect of social protection, trade liberalisation has resulted in social upgrading in the form of increased social protection for mill workers through the industry-specific social programme. With regard to the aspect of social dialogue, at the workplace level, social upgrading was found in terms of increase in workers' participation through the creation of the employee safety committee where both workers and management are represented. However, social downgrading is also evident where a part of the workforce (contractual workers) is no longer represented by the union. Further, at the national level, there is an absence of worker representation in the sugar industry policy formulation (in SRA) and in Congress.

The above changes to decent work were found to have been largely shaped by employer strategies. One employer strategy introduced was economic upgrading largely through 'process of upgrading' by installing efficient and cost-saving technology which caused the most change in decent work. Other economic upgrading strategies such as the production of higher valued products (blanco directo and muscovado sugars) and the intended 'inter-sectoral upgrading' by commercially producing power generation did not or will not result significant changes in relation to employment and work conditions. Another employer strategy was cost reduction measures through the rationalisation of worker benefits. The segmentation of workers to permanent and contractual also allowed the employer to employ numerical flexibility as a strategy. As a result, contractual workers have lost their right to be represented in the collective bargaining agreement (CBA) and earn the benefits from negotiation. Furthermore, they have been excluded from the protection of the law for permanent workers. Hence, while the positive view of trade liberalisation argues that it reduces inequality among nations, this study provides evidence of increased inequality among workers. 
The second factor that shaped the nature of decent work was the effective implementation of government (labour and environment) laws and ILO conventions which have also facilitated decent work. These include the 'Zero-Accident Program' initiated by the government and The Clean Air Act of 1997. The third factor that promoted decent work is buyer-requirements on health and safety. This has motivated the mill to improve its health and safety programme. Lastly, the fourth factor that influences decent work is the institutional framework. This has both caused social upgrading (increase) and downgrading (decrease) in the venues for social dialogue of sugar mill workers.

In conclusion, this study shows that while trade liberalisation provides some economic and social benefits, more generally, it has resulted in a decline in decent work at a workplace level. Furthermore, this study provides some interesting insights into trade liberalisation and the decent work agenda. This is summarised in the next section.

\subsection{Contributions of the Study}

This study's contributions to literature are as follows:

First, it highlights (new) trade-offs between indicators of decent work. Existing literature reports that there could be trade-offs between decrease in wages, job security, freedom of association and venue for social dialogue as against employment. As an addition, this study has discovered new trade-offs between non-performance related (non-monetary) benefits as against performance related (monetary) benefits and skills training as against workload intensification.

Second, this study reveals that institutional frameworks, both at the workplace and national levels also affect decent work. In this study, it has largely affected the 
aspect of social dialogue. Thus, it invites future research on decent work to consider institutional frameworks as a factor that shape decent work.

Third, this study also noted that in addition to labour laws, environmental laws can also shape decent work by mandating employers to provide an environmentfriendly atmosphere. This shows that the decent work agenda may be incorporated in non-labour laws.

The findings and the contributions of this research also provide some significant implications both in research and in practical application. This will be the subject of the next sections.

\subsection{Research Implications and Future Research Agenda}

There is more nuance to the impact of trade liberalisation than a mere determination as to whether it has improved decent work or not. As earlier stated, one of the key findings of this research is that it reveals the trade-offs between the indicators of decent work. Hence, part of the complexity of the impact of trade liberalisation is lost when only a few indicators or aspects of decent work are investigated. Thus, in understanding the effect of trade liberalisation, future research should consider the relationships between indicators or aspects of decent work. For instance, how one indicator of decent work complements the interpretation of another indicator (union density and the $\mathrm{CBA}$ ) or makes possible the existence of another indicator (skills training paving the way to workload intensification).

Another research implication of this study is that it invites future research to focus on contractual workers. This invitation springs from the revelation that there is a growing trend of contractualisation. The significance of further research is emphasised by the inequality of treatment both by the employer and by law between contractual and permanent workers. Considering that this research has 
only provided a partial determination that contractual workers are less benefited by trade liberalisation, the extent of effect of trade liberalisation on these groups of workers and its general applicability is an interesting topic in future research.

Furthermore, several differences were observed on the impact of trade liberalisation on sugar farm workers (SAPRIN, n.d.) and mill workers (this study) such as the difference in wages and skills. Future research may therefore consider consolidated research on the impact of trade liberalisation on these two kinds of sugar industry workers particularly on the factors that brought about the differences in results.

Lastly, agenda for future research may also include multiple case study research (amongst several sugar mills) or cross sectoral research (amongst other industries) on the impact of trade liberalisation on decent work at the workplace level.

\subsection{Policy Implications}

The thrust for decent work is a continuous positive change of the workers' condition. As such, although a certain level of improvement on decent work has been found, the findings also presented some implications and problems that may be addressed to continue improving the work conditions of sugar mill workers. These implications and recommendations are presented below.

\subsubsection{Implications for Workers}

The workers' voice is undermined by institutional frameworks. At the national level, its fragmented union structure diminishes the workers' bargaining power. At the industry level, the sugar industry workers' lack of sectoral representation means that work-related issues particualr to the sugar industry can be easily overlooked. Thus, unless the workers unite at the national level through a sectoral union and tear down the frameworks that impede the promotion of decent work, the workers bargaining power remains weak. Furthermore, the sugar industry workers will 
continue to have difficulty in addressing national issues which only concern sugar workers.

In addition, the findings that there were wage increases which were not enough to cover the increase of inflation rates also implies the need for union representatives to connect the provisions on wage increases to inflation rates in their CBA.

\subsubsection{Implications for Employers}

The reduction of sugar tariffs shows that the government's primary concern has shifted from employment-income protection to economic efficiency. Hence, trade liberalisation policies of government will continue to expose the sugar industry to international competition. This implies that sugar producers should focus in developing a more cost-efficient sugar production process to keep up with the growing competition.

\subsubsection{Implications for Government}

This study has provided evidence that workers of protected industries are negatively affected by trade liberalisation. This points out that in the pursuit for economic development through trade liberalisation, the government should consider providing measures to lessen the negative effects on workers in protected industries. Furthermore, considering that there is a growing shift towards semiskilled and skilled work opportunities, in line with the goal for employment generation, a need is created for government policy that upgrades the workforce skills of its country.

\subsubsection{Implications for the Decent Work Agenda}

The following implications for the decent work agenda have been identified:

1) Decent work may be promoted simultaneously to economic upgrading. As this study has shown, the new boiler has improved the smoke emissions of the mill which consequently improved the health of the workers. Hence, one effective way 
of promoting decent work is through the use of new technology that serves to increase profitability but at the same time improves working conditions of workers.

2) Good labour laws are not enough to ensure decent work. This fact is found in existing literature and is reiterated in this study. Laws will not produce the good results intended unless implementation is ensured. Therefore, promoters of decent work, such as the ILO, should go beyond requiring governments to enact labour laws and ratify ILO conventions. It should become involved with programmes that ensure the effective implementation of laws enacted for the benefit of workers.

3) Buyer and government requirements in this study, as indicated in other literature, have consistently been found to facilitate decent work. The implication is that it is an effective way of promoting decent work. Furthermore, government requirements have also shown to produce positive results in promoting decent work. Thus, promoters of trade liberalisation should rally the involvement of governments (in trade agreements) and civil groups (as end users) to integrate decent work as part of buyer requirements.

4) The sugar producers' social programme, as part of their industry social responsibility, has also improved the lives of sugar workers. In line with this, another challenge for the decent work agenda is how to motivate employers to be socially responsible with respect to their workers.

\subsection{Limitations of Findings}

As a single case study, findings of this study hold true only to the particular sugar mill chosen and thus only presents an initial determination with respect to the whole industry. Furthermore, the study has focused mainly on existing workers. Although it has partly discussed former workers who were separated from work (contractual workers and bus owner-operators) and whose present state of condition may be equally relevant to provide a more holistic view of the impact of 
trade liberalisation, their full story is left for future research to reveal. Additionally, sugar tariffs continue to decline and global market situations are changing. Thus the findings of this research only capture the situation at a specific point in time (as of 2011) and future changes in the mill, the industry and labour laws may modify these results.

\section{Concluding Remark}

Over all, this study highlights that trade liberalisation is disadvantageous to workers of protected industries whose cost of production could not compete with other global competitors such as the Philippine sugar mill workers. Trade liberalisation leads employers to resort to subcontracting, numerical flexibility and cost reduction measures which results in lay-offs, lesser job security and declining work conditions. Thus, this research shows that there are workers who are 'paying the price' for company efficiency and more accessible and affordable goods which are claimed to be the positive results of trade liberalisation. 


\section{References}

Aguilar, F. (1984). The making of cane sugar: Crisis and change in Negros Occidental. La Salle Social Research Center, Bacolod City, Negros Occidental.

Amante, M. (1997). Converging and diverging trends in the HRM: The Philippine “halo-halo" approach. Asia Pacific Business Review, 3(4), 111-131.

American Foreign Policy Association. (2002). Globalization's Last Hurrah? Retrieved February 23, 2012, from http:www.globalpolicy.org.globaliz/define/0101.htm.

Anker, R., Chernyshev, I., Egger, P., Mehran, F., \& Ritter, J. (2003). Measuring decent work with statistical indicators. International Labour Review, 142(2), 147-178.

Athanasou, J. (2010). Decent work and its implications for careers. Australian Journal of Career Development, 19(1), 36-44.

Atkinson, J. (1984). Manpower Strategies for Flexible Organizations. Personnel Management, August, 28-31.

Arber, S. (2008). Designing samples. In N. Gilbert (Ed.), Researching social life $\left(2^{\text {nd }}\right.$ ed.). London: Sage.

Aronson, J. (1994). A pragmatic view of thematic analysis. The Qualitative Report, 2(1). Retrieved March 20, 2012, from http://www.nova.edu/ssss/QR/Backlssues/QR2-1/aronson.html

Bangko Central ng Pilipinas. (2012). Reference exchange rate bulletin on February 2012. Retrieved February 23, 2012, from http://www.bsp.gov.ph/statistics/sdds/exchrate.htm

Barrientos, S. (2007). Global production systems and decent work. Working Paper No. 77. International Labour Organisation. Retrieved November 8, 2010, from http://www.ilo.org/wcmsp5/groups/public/---dgreports/--integration/documents/publication/wcms 085041.pdf 
Barrientos, S., Gereffi, G., \& Rossi, A. (2010). Economic and social upgrading in global production networks: Developing a framework for analysis. Retrieved June 13, 2010, from http://www.capturingthegains.org/pdf/ctg-wp-2010$\underline{03 . p d f}$

Barrientos, S., \& Smith, S. (2007). Do workers benefit from ethical trade? Assessing codes of labour practice in global production systems. Third World Quarterly 28(4), 713-729.

Bernhardt, T., \& Milberg, W. (2011). Economic and social upgrading in global value chains: Analysis of horticulture, apparel, tourism and mobile telephones. Capturing the Gains Working Paper 2011/06.

Bhalotra, S. (2002). The impact of economic liberalization on employment and wages in India. Paper submitted to the International Policy Group, ILO, Geneva. Retrieved March 19, 2012, from http://www.efm.bris.ac.uk/ecsrb/papers/indialib.pdf

Billig, M. (1993). Syrup in the wheels of progress: The inefficient organisation of the Philippine sugar industry. Journal of Southeast Asian Studies, 24 (1), 122-147. Retrieved March 1, 2012, from http://papers.ssrn.com/sol3/papers.cfm?abstract id=1987688

Bitonio Jr., B. E. (2008). Labour market governance in the Philippines: Issues and institutions. ILO Asia-Pacific Working Paper Series. International Labour Organisation. Retrieved February 24 , 2012, from http://www.ilo.org/wcmsp5/groups/public/---asia/---ro-bangkok/---ilomanila/documents/publication/wcms 123202.pdf

Bonnet, F., Figueiredo, J., \& Standing, G. (2003). A family of decent work indexes. International Labour Review, 142(2), 213-238.

Brannick, T. (1987). An overview of the research process. In T. Brannick \& W. K. Roche (Eds), Business research methods: Strategies, techniques and sources. Dublin: Oak Tree Press. 
Broadhead, R., \& Rist, R. (1976). Gatekeepers and the social control of social research. Social Problems, 23(3), 325-336. Retrieved March 3, 2012, from http://www.jstor.org/stable/pdfplus/799778.pdf?acceptTC=true

Bureau of Rural Workers. (2010). Consolidated report on the compliance of DO 7004 (4 ${ }^{\text {th }}$ Quarter 2010 Report). Manila: Department of Labor and Employment.

Bureau of Labor Relations. (2012a). Frequently Asked Questions. Retrieved May 22, 2011, from http://blr.dole.gov.ph/faqs.html

Bureau of Labor Relations. (2012b). Union Directories. Retrieved January 19, 2012, from http://blr.dole.gov.ph/UNION\%2ODIRECTORIES.html

Burgess, R. G. (1991). Sponsors, gatekeepers, members, and friends: Access in educational settings. In W. B. Shaffir \& R. A. Stebbins, (Eds.), Experiencing fieldwork: An inside view of qualitative research (43-52). Newbury Park, CA: Sage.

Camdessus, M. (1996, December 9). Promoting freer trade: The IMF's perspective. Speech at the first Ministerial Conference of the World Trade Organisation, Singapore. International Monetary Fund. Retrieved February 15, 2012, from http://www.imf.org/external/np/sec/mds/1996/mds9621.htm

Cling, J. P., Razafindrakoto, M., \& Roubaud, F. (2009). Export processing zones in Madagascar: The impact of the dismantling of clothing quotas on employment and labour standards. In R. Robertson, D. Brown, G. Pierre, \& M. L. Sanchez-Puerta (Eds.), Globalization, wages, and quality of jobs: Five country studies (203-236). Washington, D.C.: The World Bank.

Currie, J., \& Harrison, A. (1997). Sharing the costs: The impact of trade reform on capital and labor in Morocco. Journal of Labor Economics, 15(3), S44-S72.

Denscombe, M. (2007). The good research guide for small-scale social research projects ( $3^{\text {rd }}$ ed.). Maidenhead, U.K.: Open University Press. 
Denzin, N. (1984). The research act. Englewood Cliffs, NJ: Prentice Hall.

Deshingkar, P. (2009). Extending labour inspections to the informal sector and agriculture. Chronic Poverty Research Centre Working Paper No. 154. Retrieved June 8, 2011, from http://ssrn.com/abstract=1524722

Economic Research Service. (2006). USDA's sugar program response in FY 2005 to weather conditions. United States of America: Department of Agriculture. Retrieved January 18, 2012, from http://www.ers.usda.gov/Briefing/sugar/sugarpdf/SSS246weather.pdf

Feliciano, Z. (2001). Workers and trade liberalization: The impact of trade reforms in Mexico on wages and employment. Industrial and Labor Relations Review, 55(1), 95-115.

Flanagan, R. J. (2005). Globalisation and labour conditions: Working conditions and Worker Rights in a global economy. New York: Oxford University Press.

Food and Agricultural Services. (2010). Sugar: World production supply and distribution. United States of America: Department of Agriculture. Retrieved March 19, 2012, from

http://www.fas.usda.gov/htp/sugar/2010/sugarMay2010.pdf

Food and Agricultural Organisation Statistics. (2012). Food and agricultural commodities production: Countries by commodities: Sugar cane. United Nations. Retrieved February 23, 2012, from http://faostat.fao.org/site/339/default.aspx

Foreign Agricultural Service. (2011). Australia sugar semi-annual 2011. A Global Agricultural Information Network Report. United States of America: Department of Agriculture. Retrieved January 18, 2012, from http://gain.fas.usda.gov/Recent\%20GAIN\%20Publications/Sugar\%20Semiannual_Canberra_Australia 9-28-2011.pdf 
Foreign Agriculture Service. (2008). Factsheet: U.S. Sugar Program. United States of America: Department of Agriculture. Retrieved May 30, 2011, from http://www.fas.usda.gov/info/factsheets/sugar.asp

Gereffi, G. (1999). International trade and industrial upgrading in the apparel commodity chain. Journal of International Economic, 48(1), 37-70.

Gereffi, G. (2001). Shifting governance structures in global commodity chains with special reference to the internet. American Behavioral Scientist, 44(10), 16161637.

Gereffi, G., \& Korzeniewicz, M. (1994). Commodity Chains and Global Capitalism. Westport, Connecticut: Praeger Publishers.

Ghai, D. (2003). Decent work: Concept and indicators. International Labour Review, 142(2), 113-145.

Godfrey, M. (2003). Employment dimensions of decent work: Trade-offs and complementarities. Retrieved February 20, 2011, from http://www.ilo.org/public/english/bureau/inst/publications/discussion/dp14 803.pdf

Greenaway, D., \& Morrissey, 0. (1993). Structural adjustment and liberalisation in developing countries: What lessons have we learned? Kyklos, 46, 241-261.

Gross, J. A. (2010). A shameful business: The case for human rights in the American workplace. Ithaca: ILR Press/Cornell University Press.

Hayes, N. (2000). Doing psychological research: Gathering and analysing data. Buckingham, Philadelphia: Open University Press.

Held, D. (2004). A globalizing world? Culture, economics, politics (2nd ed.). London: Routledge.

Humphrey, J., \& Schmitz, H. (2002). How does insertion in global value chains affect upgrading in industrial clusters? Regional Studies, 9, 1017-1027. 
Hunt, D., Lahlou, M., Musette, S., \& Chourou, B. (2007). The employment impacts of trade liberalisation and of increased competition in export markets: The North African Clothing Sector. The Journal of North African Studies, 12(4), 453-479.

International Labour Organisation. (2006). Improving competitiveness in the textiles, clothing and footware (TCF) sectors by promoting decent work. Retrieved February 16, 2012, from http://www.ilo.org/wcmsp5/groups/public/--ed dialogue/---sector/documents/publication/wcms 162812.pdf

International Labour Organisation. (2012a). About the ILO. Retrieved June 13, 2011, from http://www.ilo.org/global/about-the-ilo/lang--en/index.htm

International Labour Organisation. (2012b). Decent work agenda: Promoting decent work for all. Retrieved June 15, 2011, from http://www.ilo.org/global/aboutthe-ilo/decent-work-agenda/lang--en/index.htm

International Labour Organisation. (2012c). Ratifications for Philippines. Retrieved February 24, 2012, from http://www.ilo.org/dyn/normlex/en/f?p=1000:11200:2421395674258520::N 0:11200:P11200 COUNTRY ID:102970

Joia, L. A. (2004). Are frequent customers always a company's intangible asset? Some findings drawn from an exploratory case study. Journal of Intellectual Capital, 5(4), 586-601.

Kalleberg, A. L. (2001). Organizing flexibility: The flexible firm in a new century. British Journal of Industrial Relations, 39, 479-504.

Kelly, B., \& Prokhovnik, R. (2004). Economic globalisation? In D. Held, (ed.). A globalizing world? Culture, economics, politics. London: Routledge.

Kelly, P. (2001). The political economy of local labor control in the Philippines. Economic Geography, 77(1), 1-22. 
Kuruvilla, S. (2006). Social dialogue for decent work. ILR Collection, Articles and Chapters, Paper 167, 175-215. Retrieved May 16, 2011, from http://digitalcommons.ilr.cornell.edu/cgi/viewcontent.cgi?artile=1168\&conte $\underline{\mathrm{xt}=\mathrm{articles}}$

Lall, S. (2003). The employment impact of globalisation in developing countries. QEH Working Paper Series - QEHWPS93. Retrieved March 16, 2012 from http://www.policyinnovations.org/ideas/policy_library/data/01177/_res/id=s a_File1/

Ledesma, J. C. (2005). Strategic management paper on Tinihaban Agricultural Corporation (Unpublished masters' thesis). De La Salle University, Bacolod City, Philippines.

Leisink, P. (1999). Introduction. In P. Leisink (Ed.), Globalization and Labour Relations. Cheltenham: Edward Elgar.

Lim, J., \& Bautista C. (2002). External liberalization, growth and distribution in the Philippines. A paper for the international conference on external liberalization, growth, development and social policy January 18-20, 2002, Hanoi, Vietnam. Retrieved January 16, 2012, from http://www.upd.edu.ph/ cba/bautista/docs/cepa-phil-0102.pdf

Locke, R., Qin, F., \& Brause, A. (2006). Does monitoring improve labor standards? Lessons from Nike. Corporate Social Responsibility Initiative, Working Paper No. 24, Cambridge, MA: John F. Kenedy School of Government, Harvard University. Retrieved November 22, 2011, from http://www.hks.harvard.edu/mrcbg/CSRI/publications/workingpaper 24 locke.pdf

Looise, J. C., van Riemsdijk, M., \& Lange, F. (1998). Company labour flexibility strategies in the Netherlands: An institutional perspective. Employee Relations, 20, 461-482. 
Lopez-Gonzaga, V. (1983). Mechanization and labor employment: A study of the sugarcane workers' responses to technological change in sugar farming in Negros. Bacolod City: Alpha Publishing Corporation.

Lund, F., \& Srinivas, S. (2000). Learning from experience: A gendered approach to social protection for workers in the informal economy. Geneva, ILO-STEP.

MacNaughton, G., \& Frey, D. F. (2011). Decent work for all: A holistic human rights approach. Retrieved February 24, 2012, from http://www.auilr.org/pdf/26/26.2.4.pdf

Mander, J., \& Goldsmith, E. (1996). The case against the global economy and for a turn toward the local. San Francisco: Sierra Club.

Matusik, S. F., \& Hill, C. W. L. (1998). The utilization of contingent work, knowledge creation, and competitive advantage. Academy of Management Review, 23, 680-697.

Mcllroy, R., Marginson, P., \& Regalia, I. (2004). Regulating external and internal forms of flexibility at local level: Five European regions compared. International Journal of Human Resource Management, 15, 295-313.

Michie, J., \& Sheehan, M. (2001). Labour market flexibility, human resource management and corporate performance. British Journal of Management, 12, 287-306.

Milberg, W., \& Winkler, D. (2008). Measuring economic and social upgrading in global production networks. Retrieved June 19, 2010, from http://www.newschool.edu/uploadedFiles/TCDS/Democracy and Diversity I nstitutes/Milberg\%20Winkler.pdf

Milner, C., \& Wright, P. (1998). Modelling labour market adjustment to trade liberalisation in an industrialising economy. The Economic Journal, 108(447), 509-528. 
Morrissey, O. (1995). Politics and economic policy reform: Trade liberalization in Sub-Saharan Africa. Journal of International Development, 7(4), 599-618.

Nagano, Y. (1988). The collapse of the sugar industry in Negros Occidental and its social and economic consequences. Kasarinlan: Philippine Journal of Third World Studies, 3(3), 59-64.

National Statistical Commission Board. (2012a). Consumer price index for all income households and headline inflation rates, January 2004-January 2012. Retrieved February 21, 2012 from, http://www.nscb.gov.ph/secstat/d price.asp

National Statistical Coordination Board. (2012b). Premier on core inflation. Retrieved on February 24, 2012, from http://www.nscb.gov.ph/stats/cpi/primer/default.asp

Neak, S., \& Robertson, R. (2009). Globalization and working conditions: Evidence from Cambodia. In R. Robertson, D. Brown, G. Pierre, \& M.L. Sanchez-Puerta (Eds.), Globalization, wages, and the quality of jobs: Five country studies (97129). Washington, D.C.: The World Bank.

Negros Occidental Tourism (n.d.). Geography and topography. Retrieved on May 25, 2012 from http://www.negrosoccidentaltourism.com/?page_id=5

New World Encyclopedia. (n.d.) Sugar. Retrieved November 8, 2011, from http://www.newworldencyclopedia.org/entry/Sugar

Nyberg, J. (n.d.). Sugar international market profile. A background paper for the Competitive Commercial Agriculture in Sub-Saharan Africa (CCAA) Study. Retrieved January 27, 2011 from http://siteresources.worldbank.org/INTAFRICA/Resources/2579941215457178567/Sugar Profile.pdf

O'Neill, G., \& Berry, A. (2002). Remuneration of Australian executives: A practitioner review. Asia Pacific Journal of Human Resources, 40(2), 228-245. 
O'Connell, P. (2010). Brave new world? Human rights in the era of globalisation. In M. Baderin and M. Ssenyonjo, (Eds.), International human rights law: 60 years after the UDHR. Retrieved March 29, 2012, from http://papers.ssrn.com/sol3/papers.cfm?abstract id=1567082

O’ Leary, Z. (2010). The essential guide to doing your research project. London: Sage. Orbeta, A. (2002). The impact of globalization on employment in the Philippines. Philippine Review of Economics, 39(2), 1-36.

Osland, J. (2003). Broadening the debate: The pros and cons of globalization. Journal of Management Inquiry, 12(2), 137-154.

Patton, M. C. (2002). Qualitative research and evaluation methods ( $3^{\text {rd }}$ ed.). Thousand Oaks, California: Sage.

Pereira, D. (2010). Is trade liberalisation a panacea for poverty? Retrieved March 19, 2012, from http://www.whydev.org/is-trade-liberalisation-a-panacea-forpoverty/

Philfaqs (n.d.) Philippines. Retrieved May 25, 2012 from http://philfaqs.com/planning/retirement-planning/philippine-retirement-right-foryou/attachment/map of philippines/

Philippine Commission on Election. (2010). 2010 national and local elections. List of candidates for national positions:Party list. Retrieved January 19, 2011, from http://www.comelec.gov.ph/2010\%20National Local/certlist partylist.html

Philippine Department of Tourism. (n.d.). General facts: Overview of the Philippines. Toronto Office. Retrieved on 18 January 2012 from http://www.wowphilippines.ca/index.php?option=com content\&view=article \&id=4:general-facts\&catid=20:philippine-information\&ltemid=23

Philippine Executive Branch. (1991). Executive order no. 470: Modifying the nomenclature and rates of import duty of certain imported articles under section 104 of the Tariff and Customs Code of 1978 (Presidential Decree No. 
1464), as amended. Retrieved March 19, 2012, from

http://www.lawphil.net/executive/execord/eo1991/eo 470 1991.html

Philippine Executive Branch. (2004). Executive order no. 295: Modifying the nomenclature and rates of import duty on sugar (heading 17.01) under section 104 of the Tariff and Customs Code of 1978 (Presidential Decree No. 1464), as amended. Retrieved March 19, 2012, from http://www.tariffcommission.gov.ph/eo 295.htm

Philippine Executive Branch. (2012). Executive order no. 892: Modifying the rates of import duty on sugar products as provided for under the Tariff and Customs Code of 1978, as amended in order to implement the tariff reduction schedule on sugar products through the invocation of the protocol to provide special consideration for rice and sugar under the common effective preferential tariff scheme for the ASEAN Free Trade Area (CEPT-AFTA)/ASEAN trade in goods agreement (ATIGA). Retrieved March 19, 2012, from

http://www.tariffcommission.gov.ph/eo 892.htm

Philippine Sugar Millers Association. (2011a). Annual summary (Crop Year 1970-71 to 2004-2055). Retrieved January 10, 2012, from http://www.psma.com.ph/index.php/statistics

Philippine Sugar Millers Association. (2011b). Members. Retrieved on January 26, 2012, from http://www.psma.com.ph/index.php/members

Pietrobelli, C., \& Rabellotti, R. (2006). Clusters and value chains in Latin America: In search for an integrated approach. In C. Pietrobelli, \& R. Rabelloti (Eds.), Upgrading to compete: Global value chains, clusters, and SMEs in Latin America (1-40). Wasington, D.C.: Inter-American Development Bank.

Piore, M., \& Schrank, A. (2006). Trading up: An embryonic model for easing the human costs of free market. Boston Review, September-October.

Quijada, M. (1979). Limitations of legislations in improving working conditions: The Venezuelan experience. International Labour Review, 118(1), 113-122. 
Ranney, D. C., \& Naiman, R. (1997). Does 'Free Trade' create good jobs? A rebuttal to the Clinton Administration's claims. Chicago: The Great Cities Institute.

Republic of the Philippines. (1973). The 1973 Constitution of the Republic of the Philippines. Retrieved, January 12, 2012, from http://www.chanrobles.com/1973constitutionofthephilippines.htm

Republic of the Philippines. (1974). Presidential decree no. 442: The labor code of the Philippines. Retrieved April 19, 2011, from

http://www.chanrobles.com/PRESIDENTIAL\%20DECREE\%20No.\%20442.\%20T HE\%20LABOR\%20CODE\%20OF\%20THE\%20PHILIPPINES.pdf

Republic of the Philippines. (1975). Presidential decree no. 851 also known as the $13^{\text {th }}$-Month Pay Law, as amended by Memorandum Order No. 28. Retrieved from http://www.chanrobles.com/revised13thmonthpayguidelines.htm on 23 February 2010.

Republic of the Philippines. (1986). Executive order no. 18: Creating the Sugar Regulatory Administration. Retrieved May 20, 2011, from http://www.sra.gov.ph/menu pdf/EO18.pdf

Republic of the Philippines. (1987a). Executive order no. 292 otherwise known as the Administrative Code of 1987. Retrieved November 16, 2011 from http://www.chanrobles.com/administrativecodeofthephilippinesfulltext.html Republic of the Philippines. (1987b). The 1987 Constitution of the Republic of the Philippines. Section 18, Article 2. Retrieved February 24, 2012 from, http://www.chanrobles.com/article2.htm

Republic of the Philippines. (1988). The Comprehensive Agrarian Reform Law of 1988. Retrieved April 5, 2011, from http://www.chanrobles.com/legal4agrarianlaw.htm

Republic of the Philippines. (1991). The Sugar Amelioration Act of 1991. Retrieved February 23, 2011, from http://www.chanrobles.com/doledepartmentorderno8-2001.html 
Republic of the Philippines. (1997). The Social Security Act of 1997. Retrieved March 1, 2011, from http://www.chanrobles.com/legal4sss.htm

Revenga, A. (1995). Employment and wages effects of trade liberalization: The case of Mexican manufacturing. World Bank Policy Research Working Paper No. 1524. Retrieved January 20, 2012, from http://papers.ssrn.com/sol3/papers.cfm?abstract id=614992

Robertson, R., Brown, D., Pierre, G., \& Sanchez-Puerta, M. L. (2009). Overview: The promises and perils of globalization. In R. Robertson, D. Brown, G. Pierre, \& M. L. Sanchez-Puerta (Eds.), Globalization, wages, and the quality of jobs: Five country studies (1-20). Washington, D.C.: The World Bank.

Robertson, R., Sitalaksmi, S., Ismalina, P., \& Fitrady, A. (2009). Globalization and working conditions: Evidence from Indonesia. In R. Robertson, D. Brown, G. Pierre, \& M. L. Sanchez-Puerta (Eds.). Globalization, wages, and quality of jobs: Five country studies (203-236). Washington, D.C.: The World Bank.

Roca-Puig, V., Beltrán-Martín, I., Bou-Llusar, J., \& Escrig-Tena, A. (2008). External and internal labour flexibility in Spain: A substitute or complementary effect on firm performance? The International Journal of Human Resource Management, 19(6), 1131-1151.

Rudman, R. (1999). Human Resources Management in New Zealand (3 ${ }^{\text {rd }}$ ed.). New Zealand: Addison Wesley Longman New Zealand Ltd.

Safa, H. (2002). Questioning globalization: Gender and export processing in the Dominican Republic. Journal of Developing Societies 18(2-3), 11-31.

Saith, A. (2004). Social protection, decent work and development. Discusion paper 152. Education and Outreach programme, International Labour Organisation. Retrieved May 18, 2011, from http://www.ilo.int/public/english/bureau/inst/publications/discussion/dp152 04.pdf 
Serrano, M. R. (2007, April). Of jobs lost and wages depressed: The impact of trade liberalization on employment and wage levels in the Philippines, 1980-2000. Paper presented in the International Conference on "Labour and the Challenges of Development", University of Witwatersrand, Johannesburg, South Africa. Retrieved February 29, 2012, from http://www.global-labouruniversity.org/fileadmin/Papers Wits conference 2007/B2/Serrano paper.p $\underline{\mathrm{df}}$

Shank, G., \& Brown, L. (2007). Exploring educational research literacy. New York: Routledge.

Skene, C. (2003). Change and continuity: Recent developments in HRM in the Philippines. Asia Pacific Business Review, 9(4), 106-128.

Skully, D. (1998). Auctioning tariff quotas for U.S. sugar imports. Economics Research Service, Department of Agriculture, United States of America. Retrieved June 15, 2011, from http://www.ers.usda.gov/publications/wto/sss223b.pdf

Solidar. (2007a). Doing a decent job? IMF policies and decent work in times of crisis. Retrieved March 7, 2012, from http://cms.horus.be/files/99931/MediaArchive/GNreport IMF\%20and\%20D $\underline{\text { W MAIL.pdf }}$

Solidar. (2007b). Working in the maquiladoras: Case study on Guatemala and Nicaragua. Retrieved March 7, 2012, from http://cms.horus.be/files/99931/MediaArchive/Decent\%20Work\%20For\%20 Development\%20-\%20brochure\%20Maquila\%20ENG-8.pdf

Solidar. (2007c). Decent work and the textile industry: Case study on Cambodia. Retrieved March 7, 2012, from http://cms.horus.be/files/99931/MediaArchive/Decent\%20Work\%20For\%20 Development\%20-\%20brochure\%20Cambodia\%20ENG-1.pdf 
Solidar. (2007d). Decent work and the agro-export industry: Case study on Peru. Retrieved March 7, 2012, from http://cms.horus.be/files/99931/MediaArchive/Decent\%20Work\%20For\%20 Development\%20-\%20brochure\%20Peru\%20ENG-7.pdf

Solidar. (2007e). Is call centre work decent? Case study on young workers in the Philippines. Retrieved March 7, 2012, from

http://cms.horus.be/files/99931/MediaArchive/Decent\%20Work\%20For\%20 Development\%20-\%20brochure\%20Filippine\%20ENG-4.pdf

Spradley, J. (1979). The ethnographic interview. New York: Holt, Rinehart \& Winston.

Structural Adjustment Participatory Review International Network. (n.d.). The impact of trade liberalization on labor in the Philippines: A summary report Too much loss for so little gain. Retrieved November 12, 2011, from http://www.saprin.org/philippines/research/phi trade sum.pdf

Sugar Regulatory Administration. (2010). Sugar Production Bulletin No. 52-a (2010 Report). Manila: Department of Agriculture.

Sugar Regulatory Administration. (2012a). Raw sugar production by producer/by affiliation. Retrieved January 20, 2011, from http://www.sra.gov.ph/list\%20federation.html

Sugar Regulatory Administration. (2012b). About us: Organisational chart. Retrieved January 12, 2012, from http://www.sra.gov.ph/aboutus orgchart.html

Sugar Regulatory Administration. (2012c). SRA historical background. Retrieved May 8, 2011, from http://www.sra.gov.ph/aboutus history1.html

Szmedra, P. (2004). Preferential trade or strong institutions: Promoting sustainable development in Fiji. The Journal of Pacific Studies, 27(2). Retrieved May 8, 2011, from http://www.usp.ac.fj/jps/PhilipSzmendra.pdf

Technical Education and Skills Development Authority. (n.d). Mandate. Retrieved November 8, 2011, from http://www.tesda.gov.ph/page.aspx?page id=11 
Tellis, W. (1997). Introduction to case study. The Qualitative Report, 3(3), 1. Retrieved on March 28, 2012 from http://www.nova.edu/ssss/QR/QR3$\underline{\text { 2/tellis1.html }}$

Theron, J., Godfrey, S., \& Visser, M. (2007). Globalization, the impact of trade liberalization, and labour law: The case of South Africa. International Labour Organization. Retrieved March 7, 2012, from http://www.ilo.org/public/english/bureau/inst/publications/discussion/dp17 807.pdf

Townend, M., \& Smith, M. (2007). A case study of cognitive-behavioral psychotherapy with a perpetrator of domestic abuse. Clinical Case Studies 6, 443-454.

Wanat, C. (2008). Getting past the gatekeepers: Differences between access and cooperation in public school research. Field Methods, 20(2), 191-208. Retrieved March 3, 2012, from http://www.brown.uk.com/teaching/HEST5001/wanat.pdf

WCSDG. (2004). A fair globalisation: Creating opportunities for all. International Labour Office, Geneva, Switzerland. Retrieved February 16, 2012, from http://www.ilo.org/public/english/wcsdg/docs/report.pdf

Wood, G., Harcourt, M., \& Harcourt, S. (2004). The effects of age discrimination legislation on workplace practice: A New Zealand case study. Industrial Relations Journal, 35(4), 359-371.

Yin, R. (1989). Case study research: Design and methods (Revised ed.). Beverly Hills, CA: Sage.

Yin, R. (2003). Applications of case study research ( $2^{\text {nd }}$ ed.). Thousand Oaks, CA: Sage.

Zarka-Martres, M., \& Guichard-Kelly, M. (2005). Decent work, standards and indicators. Working Paper No. 58. Retrieved January 10, 2012 from, 
http://www.ilo.org/wcmsp5/groups/public/---dgreports/---

integration/documents/publication/wcms 079162.pdf

Zaide, S. M. (1994). The Philippines: A unique nation. Manila: All-Nations. 


\section{APPENDIX A}

\section{Summary Chart of Literature Reviewed \\ Listed According to Topic}

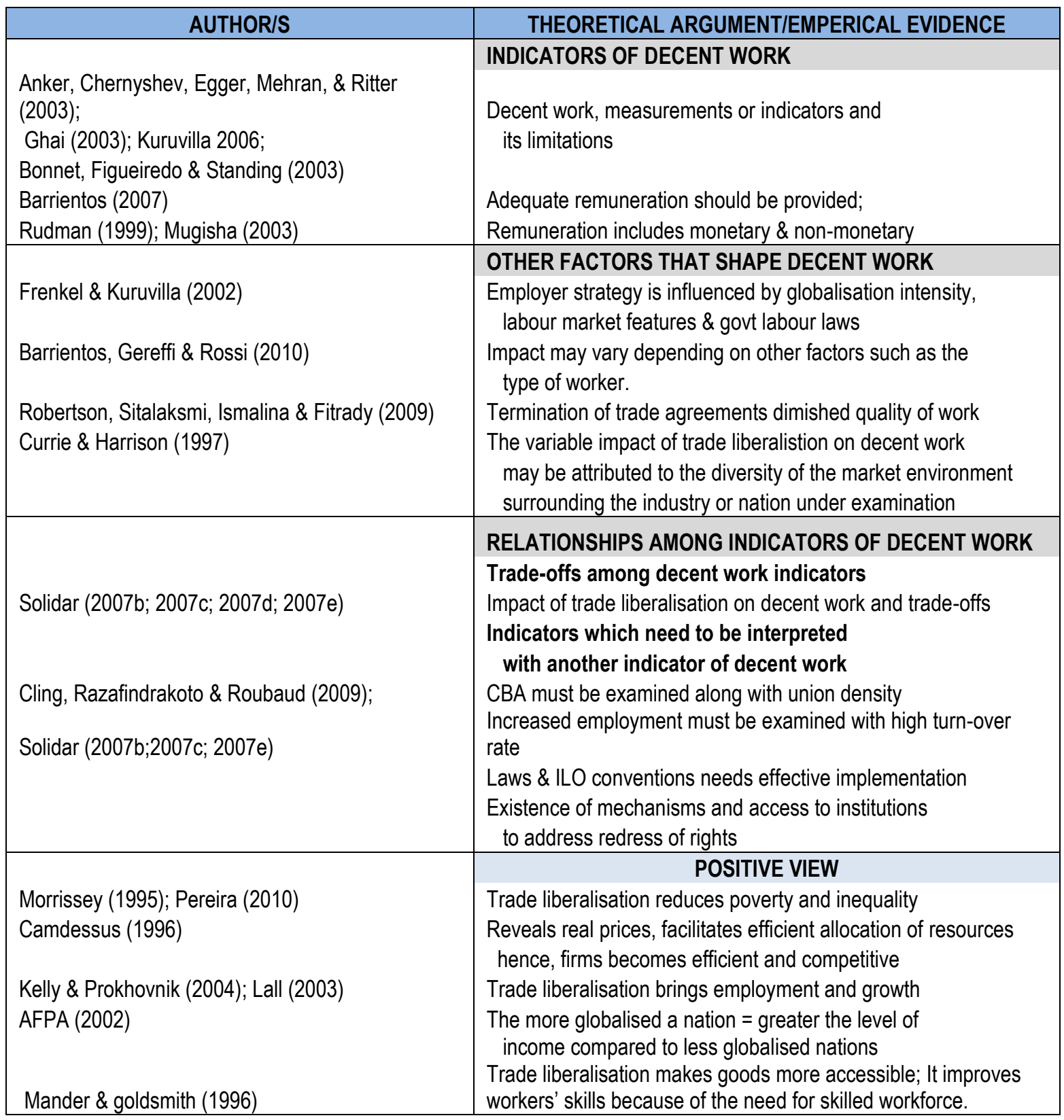




\section{APPENDIX A-1}

\begin{tabular}{|c|c|}
\hline AUTHOR/S & THEORETICAL ARGUMENT/EMPERICAL EVIDENCE \\
\hline $\begin{array}{l}\text { Gereffi, 1999; Humphrey \& Schmitz, 2002; } \\
\text { Pietrobelli \& Rabellotti (2006) } \\
\text { Ghai (2003) } \\
\text { Solidar (2007c) } \\
\text { Neak \& Robertson (2009) } \\
\text { Gereffi \& Korzeniewicz (1994) } \\
\text { ILO (2006); Deshingkar (2009) } \\
\text { Robertson, Brown, Pierre, \& Sanchez-Puerta } \\
\text { (2009) }\end{array}$ & $\begin{array}{l}\text { Economic upgrading } \\
\text { Economic upgrading (increase in productivt) results to } \\
\text { increased pay } \\
4 \text { ways of economic upgrading: Process, product, } \\
\text { functional \& intersectoral } \\
\text { Buyer-requirements } \\
\text { Quality of employment is affected by differences } \\
\text { in the nature and structure of work and consumer demand } \\
\text { compliance to labour laws became effective when } \\
\text { Decent work was integrated as part requirement of the US } \\
\text { market coupled with ILO inspections } \\
\text { In buyer-driven industries, retailers exercises influence } \\
\text { Buyer-driven requirements drive social upgrading } \\
\text { Trade liberalisation motivated government and NGOs to take } \\
\text { active \& different roles in influencing decent work }\end{array}$ \\
\hline $\begin{array}{l}\text { Orbeta (2002) } \\
\text { Ranney \& Naiman (1997) } \\
\text { Bhalotra (2003); Cling et. Al (2009) } \\
\text { Bernhardt \& Milberg (2011) } \\
\text { Solidar (2007b; 2007c; 2007d; 2007e) }\end{array}$ & $\begin{array}{l}\text { Increased employment } \\
\text { Export-import flows = increased shift to export-orientation } \\
\text { which resulted in increase in aggregate employment } \\
\text { Increase in imports has no effect on labour demand } \\
\text { Import-export figures does not apply to the Philippines } \\
\text { were import exceeds export } \\
\text { Increase in export market = increased employment } \\
\text { Growth in export market share resulted to increase } \\
\text { in employment demand (except in tourism sector) } \\
\text { Increase in employment }\end{array}$ \\
\hline $\begin{array}{l}\text { Bernhardt \& Milberg (2011) } \\
\text { Revenga (1995) }\end{array}$ & $\begin{array}{l}\text { Increased real wages } \\
\text { various countries - Growth in export market share resulted to } \\
\text { increase in real wages (except in tourism sector) } \\
\text { India - Decrease in employment coupled with the } \\
\text { increase in wages; Taken as a sign of increased productivity } \\
\text { as well as a shift towards more skilled workers }\end{array}$ \\
\hline $\begin{array}{l}\text { WCSDG (2004) } \\
\text { Solidar (2007a) }\end{array}$ & $\begin{array}{l}\text { CRITICAL VIEW } \\
\text { Still inequality because it tends to benefit capital } \\
\text { significantly more than labour } \\
\text { No incentive for employers to share the benefits of higher } \\
\text { productivity derived from freer trade with their workers. } \\
\text { Trade liberalisaiton has resulted in uneven social and economic } \\
\text { impact among and within countries } \\
\text { IMF's priority remains focused on economic development; } \\
\text { When cutbacks are imposed, funds from basic social } \\
\text { protection or services for workers are reduced }\end{array}$ \\
\hline
\end{tabular}




\section{APPENDIX A-2}

\begin{tabular}{|c|c|}
\hline AUTHOR/S & THEORETICAL ARGUMENT/EMPERICAL EVIDENCE \\
\hline & JOB GENERATION \& QUALITY OF WORK \\
\hline & Decreased employment and real wages \\
\hline SAPRIN (n.d.) & $\begin{array}{l}\text { Philippines - Trade liberalisation led to closure of establishments } \\
\text { (reduced employment); Grant of importation has } \\
\text { reduced income of sugar farm workers. }\end{array}$ \\
\hline Serrano (1997) & $\begin{array}{l}\text { Philippines - Trade liberalisaiton has caused unemployment; } \\
\text { reduction in real wages }\end{array}$ \\
\hline Solidar (2007b; 2007c; 2007d; 2007e) & Various countries - Reduction in wages \\
\hline Revenga (1995) & Mexico - Decrease in employment (but with increased wages) \\
\hline Feliciano (2001) & Mexico -Tariff reduction has no effect on employment \\
\hline Ghai (2003) & $\begin{array}{l}\text { Job generation should also consider the quality of employment } \\
\text { Work benefits }\end{array}$ \\
\hline $\begin{array}{l}\text { Robertson, Sitalaksmi, Ismalina } \\
\text { \& Fitrady (2009) }\end{array}$ & $\begin{array}{l}\text { Termination of Multi-fibre Agreement reduced export results to } \\
\text { decrease in profits, work benefits remained stagnant } \\
\text { Flexibility; Segmentation of workers }\end{array}$ \\
\hline $\begin{array}{l}\text { Roca-Puig, Beltrán-Martín, } \\
\text { Bou-Llusar, \& Escrig-Tena (2008) }\end{array}$ & $\begin{array}{l}\text { Internal flexibility is usually facilitated by hiring highly qualified } \\
\text { employees or through the firm's continuous training } \\
\text { programme; External or numerical flexibility is done by } \\
\text { subcontracting and employing contraual or temporary workers }\end{array}$ \\
\hline Bhalotra (2003) & Mexico - Growing change from self-employment to casualisation \\
\hline Robertson, Sitalaksmi, Ismalina \& Fitrady (2009) & $\begin{array}{l}\text { Shift towards informalisation. Employment became irregular; } \\
\text { It has become dependent on product demand } \\
\text { Indonesia- Because work is contingent upon duration of the } \\
\text { orders, employers hire only contractual workers. }\end{array}$ \\
\hline SAPRIN (n.d.) & $\begin{array}{l}\text { Preference for casual and temporary workers in lieu of } \\
\text { permanent workers; subcontracting and paying by piece rates }\end{array}$ \\
\hline Hunt, Lahlou, Musette \& Chourou (2007) & $\begin{array}{l}\text { Employers are preferring those who are better educated } \\
\text { hence, many accepted employment at a lower wage }\end{array}$ \\
\hline Revenga (1995) & $\begin{array}{l}\text { employment was favourable to the nonproduction } \\
\text { (skilled) workers than production (unskilled) workers. } \\
\text { Declining conditions of work }\end{array}$ \\
\hline Solidary (2007b; 2007c; 2007d; 2007e) & $\begin{array}{l}\text { Various countries - Trade liberalisation resulted to increased } \\
\text { work hours, casualisation, union membership discrimination, } \\
\text { health and safety issues. }\end{array}$ \\
\hline & Workers' skills \& training \\
\hline Lim \& Bautista (2002) & $\begin{array}{l}\text { Decrease in low-skilled workers with a simultaneous } \\
\text { increase in skilled and managerial workers }\end{array}$ \\
\hline & $\begin{array}{l}\text { The reason: a shift of employment from unskilled to skilled } \\
\text { across sectors rather than a change in the composition of } \\
\text { skilled or unskilled workers. }\end{array}$ \\
\hline Robertson, Sitalaksmi, Ismalina \& Fitrady (2009) & $\begin{array}{l}\text { Indonesia - Termination of Multi-fibre Agreement reduced export; } \\
\text { As a result, profits declined, hence, trainings were terminated. }\end{array}$ \\
\hline
\end{tabular}




\section{APPENDIX A-3}

\begin{tabular}{|c|c|}
\hline AUTHOR/S & THEORETICAL ARGUMENT/EMPERICAL EVIDENCE \\
\hline & RIGHTS AT WORK \\
\hline & Laws \& ILO conventions \\
\hline Ghai (2003) & $\begin{array}{l}\text { The ILO has mainly relied on government legislations and } \\
\text { ratification of llo conventions }\end{array}$ \\
\hline Pereira (2010) & Trade liberalisation has increased violation of workers' rights \\
\hline O'Connell (2010) & $\begin{array}{l}\text { HR are facilitated by govt interventions. However, the trend of } \\
\text { trade liberalisaiton, deregulation \& privatisation has } \\
\text { taken social services away from government to private } \\
\text { institutions, thus services has been commercialised }\end{array}$ \\
\hline Quijada (1979) & $\begin{array}{l}\text { Compliance and applicability of the law may differ } \\
\text { according to the locality and nature of work or the status } \\
\text { of employment }\end{array}$ \\
\hline Ghai (2003) & $\begin{array}{l}\text { Challenges is ensuring that these rights are respected; } \\
\text { Particularly true for unskilled workers }\end{array}$ \\
\hline Anker, et al. & $\begin{array}{l}\text { Existence of mechanisms and access to institutions } \\
\text { to address redress of rights }\end{array}$ \\
\hline Solidar (2007b) & $\begin{array}{l}\text { Violations on ILO Conventions e.g. discrimination } \\
\text { against migrant workers, child labour }\end{array}$ \\
\hline \multirow{3}{*}{$\begin{array}{l}\text { Wood, Harcourt and Harcourt (2004) } \\
\text { Qin \& Brause (2006) }\end{array}$} & Non-compliance on law against age discrimination \\
\hline & $\begin{array}{l}\text { Different monitoring styles were needed to } \\
\text { facilitate the implementation of labour standards. }\end{array}$ \\
\hline & $\begin{array}{l}\text { Even at plant level, companies management monitoring style } \\
\text { was found to have little influence on compliance } \\
\text { with labour standards }\end{array}$ \\
\hline \multirow{3}{*}{ Kuruvilla (2006) } & $\begin{array}{l}\text { SOCIAL DIALOGUE } \\
\end{array}$ \\
\hline & Includes all types of negotiation, .. At all levels \\
\hline & $\begin{array}{l}\text { Indicators have limitations. Example, in CBA, some workers such } \\
\text { as those in informal sectors are not represented in negotiations }\end{array}$ \\
\hline Ghai (2003) & $\begin{array}{l}\text { Bargaining agents may not effectively represent the } \\
\text { 'voice' of the workers }\end{array}$ \\
\hline Kelly (2001) & $\begin{array}{l}\text { Workers should not be merely seen as victims or beneficiaries of } \\
\text { trade liberalisaiton but as active players who can } \\
\text { influence the dynamics of the changing work conditions }\end{array}$ \\
\hline Serrano (1997) & $\begin{array}{l}\text { Emphasises the role of labour unions as important in } \\
\text { maintaining favourable working conditions for } \\
\text { workers e.g. negotiating for increase wages; } \\
\text { Recommends a concerted effort by labour unions }\end{array}$ \\
\hline \multirow{3}{*}{$\begin{array}{l}\text { Anker, Chernyshev, Egger, Mehran \& Ritter (2003); } \\
\text { Ghai (2003); Kuruvilla (2006) } \\
\text { Lund \& Srinivas (2000) }\end{array}$} & SOCIAL PROTECTION \\
\hline & $\begin{array}{l}\text { Social protection is operationalised by existence and } \\
\text { coverage of social protection programme }\end{array}$ \\
\hline & $\begin{array}{l}\text { Labourers especially in the informal economy have no } \\
\text { social protection coverage }\end{array}$ \\
\hline
\end{tabular}




\section{APPENDIX A-4}

\begin{tabular}{|l|l|}
\hline \multicolumn{1}{|c|}{ AUTHOR/S } & THEORETICAL ARGUMENT/EMPERICAL EVIDENCE \\
\hline \multirow{5}{*}{ Amante (1997) } & HUMAN RESOURCE PRACTICES IN THE PHILIPPINES \\
& Analysed the employment practices in the Philippines. \\
& Employment practices are influenced by the west (due to \\
& colonisation) and at the same time a reflection of some \\
& traditional local practices \\
& Predominant employer strategy is numerical and wage \\
& flexibility with a little functional flexibility; the use of casual \\
& workers and contracting; training was on-the-job \\
& Employers pursue cost-reduction strategies. \\
& Recent developments in HRM in the Philippines. Talks about the \\
& changing employment practices of the import substitution \\
& industrialisation (ISI) sector shifting to practices found in the \\
& export-oriented industrialisation (EOI) sector \\
\hline
\end{tabular}




\section{APPENDIX B}

\section{Questionnaire for the Employers' Representatives (Sugar millers and Sugar Planters)}

\section{A. ORGANISATION'S BACKGROUND}

1. Please describe the role of your organisation in the sugar industry?

2. Has this role changed when the organisation was initially created?

3. What are the main functions of your organisation with respect to the sugar industry?

\section{B. THE GLOBAL COMMUNITY CHAIN}

4. Please describe the sugar commodity chain for sugar production

a. Who are the actors along the commodity chain?

b. What are the roles of these actors?

\section{CHALLENGES IN THE SUGAR INDUSTRY}

5. What are the challenges that the sugar industry is facing?

a. International/global

b. Local (national)

6. How is the sugar industry coping with these challenges?

7. What are the difficulties in coping with these challenges? 


\section{EFFECT AND INFLUENCE TO WORKER'S CONDITION}

8. How do you think will these challenges affect the employment strategies of sugar millers (employers)?

9. How do you think will these challenges and employment strategies affect the working conditions of sugar mill workers?

10. What is the role of the sugar producers in improving the work conditions of sugar mill workers?

11. What do you think are the challenges in improving the working conditions of sugar mill workers? (in terms of number of workforce, quality of employment, salary, health and safety, etc.)

12. Do you have anything to add in relation to the topic we discussed? 


\section{APPENDIX C}

\section{Questionnaire for the Labour Union's Representatives}

A. ORGANISATION'S BACKGROUND

1. Please describe the role of your organisation in relation to the sugar mill workers.

2. Has this role changed when the organisation was initially created?

3. What are the main functions of your organisation with respect to the sugar mill workers and the sugar industry?

B. UNION STRUCTURE, WORKERS' VOICE AND WORK CONDITIONS

4. Please describe the structure of labour unions in the Philippines. How have this structure evolved?

5. How has this structure affect the effectivity of workers' representation in labour policy consultation?

6. How are workers' policies formulated?

7. How are sugar mill workers consulted in labour policy formulation at the national level?

8. How are sugar mill workers consulted in policy formulation at the (sugar) industry level?

9. How effective is this consultation process?

10. What are the challenges with respect to sugar workers when it comes to having a say on labour policies? 
11. What are the hindrances to improving the working conditions of sugar mill workers? (Re: number of workforce, quality of employment, salary, health and safety, etc.)

12. Do you have anything to add in relation to the topic we discussed? 


\section{APPENDIX D}

\section{Questionnaire for the Government Sector Representative}

\section{A. ORGANISATION'S BACKGROUND}

1. Please describe the role of your organisation in the sugar industry.

2. Has this role changed when the organisation was initially created?

3. What are the main functions of your organisation with respect to the sugar industry?

4. How do government policies affect the sugar mills?

5. How do government policies affect the sugar mill workers?

B. POLICY FORMULATION

6. How are sugar industry policies formulated?

7. Who participates in the formulation of sugar policies?

8. How do sugar policies affect the sugar mills?

9. How do sugar policies affect the sugar mill workers?

\section{CHALLENGES IN THE SUGAR INDUSTRY}

10. What are the challenges faced by the sugar industry? 
11. What is your organisation's role in these challenges?

12. How will these challenges affect the working conditions of sugar mill workers?

(e.g. number of workforce, quality of employment, salary, health and safety, etc.)

13. Do you have anything to add in relation to the topic we discussed? 


\section{APPENDIX E}

\section{Questionnaire for the Sugar Mill Managers}

A. DEMOGRAPHICS

1. Please briefly describe the sugar mill:

- Date of initial operation

- Presence of competition

- Organisational Structure

- Manpower composition

2. Please briefly describe how sugar is produced.

\section{B. ECONOMIC UPGRADING}

3. What changes did the mill undergo from 1990 to present?

- $\quad$ Upgrading processes/operations

- Upgrading products

- $\quad$ Entering new market/sectors

4. How did these changes affect the sugar mill?

a. How did these changes affect the number of workforce in the sugar mill?

b. How did these changes affect the conditions of work of the mill workers? (in terms of quality of employment, salary, health and safety, bargaining agreements, consultation policies, etc.)

c. What are the factors/reasons that led to these changes?

5. Do you have anything to add in relation to the topic we discussed? 


\section{APPENDIX F. \\ Questionnaire for the Sugar Mill Workers (and supervisors)}

A. DEMOGRAPHICS

1. When did you start working with the sugar mill?

2. What was your initial (entry) position?

3. Please describe your main task in your initial position.

4. What is your current position?

5. Please describe your main task in your current position.

\section{B. JOB GENERATION/QUALITY OF EMPLOYMENT}

6. How has your job changed since you first started working with the sugar mill?

- Workload

- Work hours

- Wage/Salary

- Health and safety

- Representation to management

7. What are the factors/reasons that led to these changes?

8. What are the skills training you have taken since you started working for the sugar mill?
a. Who initiate this training?
b. Who paid for this training?
c. Why did you undergo these training? 
9. What are the benefits that you are receiving from the sugar mill?

10. Have these benefits changed over time?

11. What are the factors that led to these changes?

C. RIGHTS AT WORK

12. What labour laws are you familiar of?

13. Are these laws implemented by the sugar mill management?

14. How have these laws affect your working condition?

15. How is your freedom of association and right to form labour unions being implemented at work?

D. SOCIAL PROTECTION

16. Do you have social protection coverage?

17. Who pays for this social protection coverage?

\section{E. SOCIAL DIALOGUE}

18. Are you a member of a labour union? For how long? 
19. What benefits do you get from being a member of a labour union?

20. What is the role of your labour union?

21. How effective is your labour union in representing your concerns to management?

22. How has the role of the labour union changed over time?

23. Are there other venues in airing your concerns about your work other than through the labour union?

24. Do you have anything to add in relation to the topic we discussed? 


\title{
APPENDIX G
}

\section{A copy of the letter to the mill}

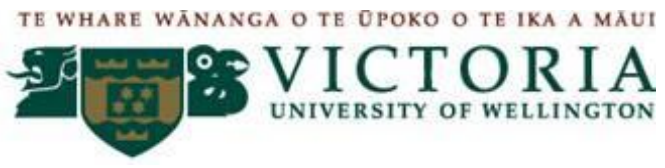

\author{
Cristobal Street \\ Hofileña Subdivision \\ Silay City, Negros Occidental
}

(Date)

Dear Sir/Madam:

My name is Johana Sellado Jadoc. I am currently a student at Victoria University of Wellington undertaking a Masters in Commerce and Administration. As part requirement of my degree, I must undertake an independent piece of research. I write to you to request permission to undertake this research at your sugar mill.

The research is about the impact of globalisation to the social upgrading of workers. It relates to the wider debate on social upgrading in relation to trade liberalization in the Philippines. The focus of this research will be on the sugar mill workers. It will look at the factors shaping the social upgrading of the sugar mill workers by interviewing national level representatives of sugar workers, sugar mill management and the government sector. The information will be further supplemented by a case study of one sugar mill in Negros Occidental. I am interested in documenting the changes of work conditions of the sugar mill workers since the Philippines agreed to trade liberalization. I will be using the ILO's four pillars of 'decent work' namely: 1 . rights at work; 2 . creating jobs; 3 . Social protection; and 4. social dialogue in determining the social upgrading of workers. To guide you in your decision, I have attached the questionnaires for the workers and the managers. Should your mill consent to participate, this is how your mill may be affected: 
1. This research is purely voluntary on the part of the mill and on the part of the individual participants.

2. I will be interviewing about $10 \%$ of your permanent workers and $10 \%$ of your seasonal workers. Further, I will be interviewing 2 managers to represent the management's perspective.

3. A list of all your employees will be requested. The participants will be selected randomly from the list. The selected employee will be invited (via postal mail or email) to participate in the study. The interview will be outside of office hours and at the venue preferred by the participant. The same procedure will be followed in selecting the managers.

4. This is independent research which has sought and received ethics approval from the Pipitea Human Ethics Committee of the Victoria University of Wellington. All data will be restricted to the researcher. As such, the final write up will be in aggregate form using fictitious names to hide the identities of the participant, including the name of the sugar mill. The participants' identities shall be kept in anonymity by the researcher from the mill management, its employees or any individual or body, government or either wise.

5. Although the identities of the participants will be kept anonymously, nevertheless, the sugar mill management undertakes that participants in the study will not be in any way discriminated nor disadvantaged by reason of their participation.

6. The final write up will be deposited at the library of Victoria University of Wellington, the Philippine Commission on Higher Education and the Sugar Regulatory Administration.

The above information is provided to ensure that you as the authorized representative of the chosen mill in this research project, are informed of the purpose of this study and how your mill will be affected including your mill and your employees' rights to confidentiality. 
Kindly fill up, detach the reply slip and send it to:

Email address: jadocjoha@myvuw.ac.nz

Or Postal address: Johana S. Jadoc

Cristobal Street, Hofileña Subdivision

Silay City, Negros Occidental, 6116

Should you have further questions, I can be reached through email or the contact details below.

Thank you for your attention.

Respectfully yours,

JOHANA S. JADOC

Telephone Number +63-34-4954343

Cellular phone Number $+63-920-9090234$

\section{RETURN SLIP}

(Date)

Dear Ms. Jadoc:

Please tick the box corresponding to your response below.

Yes, our mill is willing to participate in your research project.

Sorry, we cannot accommodate your request.

Kindly send the Return Slip through:

Email address: jadocjoha@myvuw.ac.nz

or

Postal address:

Johana Jadoc

Cristobal Street, Hofileña Subdivision

Silay City, Negros Occidental, 6116 


\title{
APPENDIX H
}

\section{A copy of the Information Sheet for the Private Sector Respondents}

\author{
TE WHARE WÁNANGA O TE OPOKO O TE IKA A MAUT

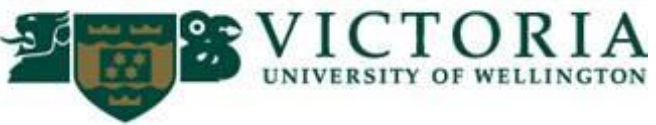 \\ PARTICIPANT'S INFORMATION SHEET \\ For participants from the private sector
}

Dear Sir/Madam,

My name is Johana Sellado Jadoc. I am currently a student at Victoria University of Wellington undertaking a Masters in Commerce and Administration. As part requirement of my degree, I must undertake an independent piece of research. I write to you to seek your support to participate in this research.

This research looks at the factors shaping the social upgrading of the sugar mill workers. The focus of this research will be on the sugar mill workers in the Negros Occidental province where majority of the Philippine sugar is produced. This study has sought and received ethics approval from the Pipitea Human Ethics Committee of the Victoria University of Wellington.

Given your experience and knowledge in your field of work, I am writing to invite you to participate in this study.

This information sheet is provided to ensure that you, as participants of this research project, are informed of the purpose of this study and how you will be affected including your right to confidentiality.

\section{HOW YOU WILL BE AFFECTED}

1. Your mill was requested to provide the researcher with all the names of its employees (and their addresses) categorised whether the employee is a permanent or seasonal worker. You have been randomly selected (by means of drawing of names or lottery method) to be a participant. However, your participation is completely voluntary.

2. A one-on-one interview will be conducted (face-to-face). The interview will run for about 30 to 60 minutes. 
3. The interview will be digitally voice-recorded so I can make a more accurate summary of the interview.

4. Confidentiality will be strictly enforced. Your responses will be kept confidential and your individual identity will not be revealed. To enforce confidentiality, the digital copy of the recorded interview shall be kept in a password protected file and will be available only to the researcher. All written data from this project will be kept in a locked file and will be restricted to the researcher. The data will be released in aggregate form and the identity of the interviewees shall be hidden using fictitious names in the final write up. Any data on which the results of the project depend may be retained in anonymous form in secure storage for three (3) years, after which they will be destroyed.

5. You may be provided with the written summary of the interview should you request for it by indicating in the Consent Form. You will have a period of 4 weeks from receipt of the written summary within which to communicate to me (contact information provided at the bottom) your comments or objections or to edit any part of the written summary or withdraw your participation including all information you have provided without any negative consequence on your part. However, after the period of 4 weeks and no communication was received, it shall be understood that you concurred with the written summary and agreed to the use of the information you have provided.

6. Your mill management will not be aware that you have been selected. Nevertheless, it has consented that participants will not be discriminated in any way by reason of their participation.

7. You will be given the opportunity to request a summary of the research findings by indicating it in the Consent Form.

8. The final copy of the research (note that data is in aggregate form) will be deposited with the Victoria University of Wellington library, the Commission on Higher Education and the Sugar Regulatory Administration. The study, when accepted, may also be published in academic or professional journals.

9. Everyone who agrees to participate in this research shall sign a consent form where they will indicate how they want the information received to be handled. The consent form shall be signed by the researcher prior to handing a copy to the interviewee. The interviewee shall then sign the consent form prior to the interview and shall return the form to the researcher via email or regular mail. 
Should you have further queries, please feel free to contact the researcher.

RESEARCHER'S CONTACT DETAILS:

JOHANA SELLADO JADOC

Candidate, MCA in HRIR

Victoria Management School

Victoria University of Wellington, New Zealand

Email address: jadocjoha@myvuw.ac.nz

Victoria University, Wellington, New Zealand

Cell phone no. +64-220-779539

Contact details in the Philippines:

Cristobal Street, Hofileña Subdivision

Silay City, Negros Occidental

Philippines

Email address: : jadocjoha@myvuw.ac.nz

Cell phone no. +63-920-9090234
SUPERVISOR'S CONTACT DETAILS:

\section{Dr. NOELLE DONNELLY}

Supervisor

Level 10, Rutherford House

Victoria Management School

Email address:

Noelle.Donnelly@vuw.ac.nz

Telephone: +64-4-4635704.

Dr. Stephen Blumenfeld

Co-supervisor

Level 10, Rutherford House

Victoria Management School

Email address:

Stephen.Blumenfeld@vuw.ac.nz 


\title{
APPENDIX I
}

\section{A copy of the Information Sheet for the Government Sector Respondents}

\author{
TE WHARE WÁNANGA O TE OPOKO O TE IKA A MAUT \\ S9: \\ PARTICIPANT'S INFORMATION SHEET \\ For Government Officials
}

Dear Sir/Madam,

My name is Johana Sellado Jadoc. I am currently a student at Victoria University of Wellington undertaking a Masters in Commerce and Administration. As part requirement of my degree, I must undertake an independent piece of research. I write to you to seek your support to participate in this research.

This research looks at the factors shaping the social upgrading of the sugar mill workers. The Philippines is a country-member of the International Labour Organisation (ILO). Under the ILOs' 'decent work' agenda, governments are encouraged to focus on social upgrading of workers. The focus of this research will be on the sugar mill workers in the Negros Occidental province where majority of the Philippine sugar is produced. This study has sought and received ethics approval from the Pipitea Human Ethics Committee of the Victoria University of Wellington.

Given your experience and knowledge in your field of work, I am writing to invite you to participate in this study.

This information sheet is provided to ensure that you, as participants of this research project, are informed of the purpose of this study and how you will be affected including your right to confidentiality.

\section{HOW YOU WILL BE AFFECTED}

1. You have been randomly selected to be a participant. However, your participation is completely voluntary.

2. A one-on-one interview will be conducted (face-to-face) at your preferred time and venue. The interview will run for about 30 to 60 minutes. 
3. The interview will be digitally voice-recorded so I can make a more accurate summary of the interview.

4. To enforce confidentiality, the digital copy of the recorded interview shall be kept in a password protected file and will be available only to the researcher. All written data from this project will be kept in a locked file and will be restricted to the researcher. The data will be released in aggregate form and the identity of the interviewees shall be hidden using fictitious names in the final write up. Data on which the results of the project depend may be retained in anonymous form in secure storage for three years, after which they will be destroyed.

5. As it is a practice in the Philippines in conducting interviews with government agencies to seek consent from the head of offices or interview their designated representatives, it is still possible that you may be identified. You will be provided with the written summary of the interview. You will have a period of 4 weeks from receipt of the written summary within which to communicate to me (contact information provided at the bottom) your comments or objections or to edit any part of the written summary or totally withdraw your participation including all information you have provided without any negative consequence on your part. However, after the period of 4 weeks and no communication was received, it shall be understood that you concurred with the written summary and to the use of the information you have provided.

6. You will be given the opportunity to request a summary of the research findings by indicating it in the Consent Form.

7. The final copy of the research (note that data is in aggregate form) will be deposited at the Victoria University of Wellington library, the Commission on Higher Education and the Sugar Regulatory Administration. The study, if accepted, may also be published in academic or professional journals.

8. Everyone who agrees to participate in this research shall sign a consent form where they will indicate how they want the information received to be handled. The consent form shall be signed by the researcher prior to handing a copy to the interviewee. The interviewee shall then sign the consent form prior to the interview and shall return the form to the researcher via email or regular mail. 
Should you have further queries, please feel free to contact the researcher.

RESEARCHER'S CONTACT DETAILS:

\section{JOHANA SELLADO JADOC}

Candidate, MCA in HRIR

Victoria Management School

Victoria University of Wellington, New Zealand

Email address: jadocjoha@myvuw.ac.nz

Victoria University, Wellington, New Zealand

Cell phone no. +64-220-779539

Contact details in the Philippines:

Cristobal Street, Hofileña Subdivision

Silay City, Negros Occidental

Philippines

Email address: : jadocjoha@myvuw.ac.np

Cell phone no. +63-920-9090234
SUPERVISOR'S CONTACT DETAILS:

\section{Dr. NOELLE DONNELLY}

Supervisor

Level 10, Rutherford House

Victoria Management School

Email address:

Noelle.Donnelly@vuw.ac.nz

Telephone: +64-4-4635704.

Dr. Stephen Blumenfeld

Co-supervisor

Level 10, Rutherford House

Victoria Management School

Email address:

Stephen.Blumenfeld@vuw.ac.nz 


\section{APPENDIX J}

\section{A Copy of the Consent Form for Private Sector Respondents}

\section{PARTICIPANT'S}

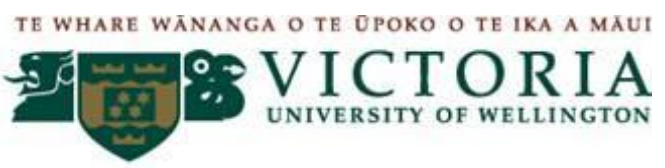

(The purpose of this agreement is to indicate your consent to participate in this research project and your right to confidentiality.)

I have been given the Participant's Information Sheet explaining the nature and purpose of this research project and I have understood the same including my right to confidentiality. I have been given the opportunity to ask questions and have them answered to my satisfaction. I understand that I am free to request further information at any stage.

I am made aware that:

1. I have been randomly selected (for workers) or particularly selected (for national level representatives) as a participant and my participation in this research is voluntary.

2. My interview will be recorded and hand-written notes will be taken.

3. Confidentiality will be enforced by the researcher and I may be provided with the written summary of the interview by indicating below. I have a period of 4 weeks from receipt of the written summary within which to communicate my comments or objections or to edit any part of the written summary or to withdraw my participation including all information I have provided without any negative consequence on my part.

4. After the period of 4 weeks and I have not given my comments or objections, or withdraw my participation, it shall be understood that I concurred with the written summary and agreed to the use of the information I have provided.

5. The information derived from the interview will be used solely for this research project and any further use shall require my consent.

6. The final write up will be deposited with the Commission on Higher Education and the Sugar Regulatory Administration. I am further aware that when accepted, the study may be published in academic or professional journals.

I agree to take part in this research project. 
Optional - Please tick the box if appropriate.

$\square$ I am requesting a written summary of my interview. Kindly send it to me through Email address:

or Postal address:

I am requesting a summary of the final write up at the email or postal address written above.

Participant

Name :

Signature:

Date:

NOTE: After filling in name, date and affixing signature, please send this Consent Form to

Email: jadocjoha@myvuw.ac.nz

Or Postal address:

JOHANA SELLADO JADOC

Cristobal Street, Hofileña Subdivision, Silay City Negros Occidental, Philippines, 6116

Date:

\section{Researcher}

Name : Johana Sellado Jadoc 


\section{APPENDIX K}

\section{A Copy of the Consent Form for Participants from the Government Sector}

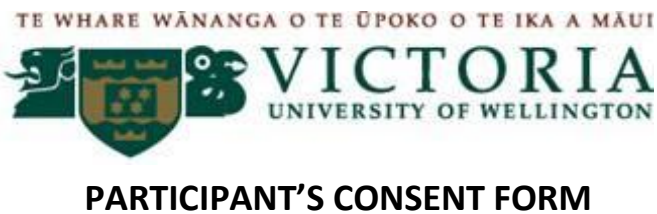

For Government Officials

(The purpose of this agreement is to indicate your consent to participate in this research project and your right to confidentiality.)

I have been given the Participant's Information Sheet explaining the nature and purpose of this research project and I have understood the same including my right to confidentiality. I have been given the opportunity to ask questions and have them answered to my satisfaction. I understand that I am free to request further information at any stage.

I am made aware that:

1. My participation in this research is voluntary.

2. The organisation to which I am affiliated will be revealed which makes it difficult to keep my identity anonymous.

3. My interview will be recorded and hand-written notes will be taken.

4. I will be provided with the written summary of the interview; That I have a period of 4 weeks from receipt of the written summary within which to communicate my comments or objections or to edit any part of the written summary or to withdraw my participation including all information I have provided without any negative consequence on my part.

5. After the period of 4 weeks and I have not given my comments or objections, or withdraw my participation, it shall be understood that I concurred with the written summary and agreed to the use of the information I have provided.

6. The information derived from the interview will be used solely for this research project and any further use shall require my consent.

7. The final write up will be deposited with the Commission on Higher Education and the Sugar Regulatory Administration. I am further aware that when accepted, the study may be published in academic or professional journals. 
I agree to take part in this research project.

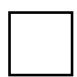

Optional - Please tick the box if appropriate.

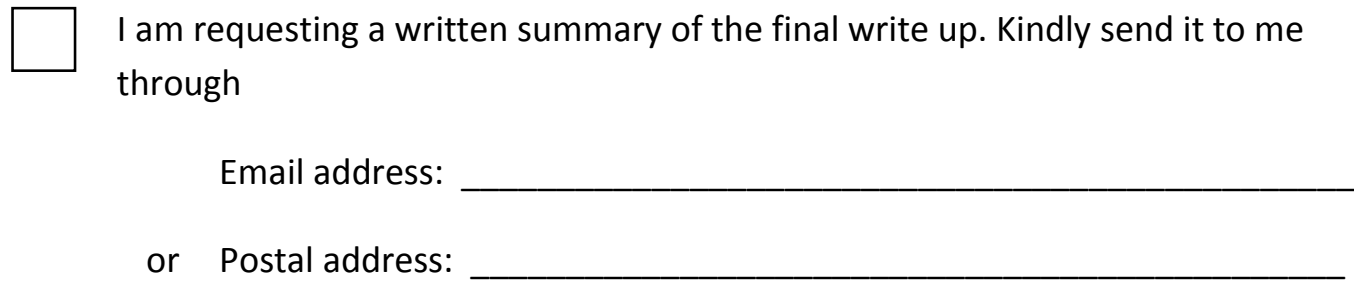

\section{Participant}

Name :

Signature:

Date:

\section{Researcher}

Name : Johana Sellado Jadoc

Signature:

Date:

NOTE: After filling in name, date and affixing signature, please send this Consent Form to

Email: jadocjoha@myvuw.ac.nz

Or Postal address:

JOHANA SELLADO JADOC

Cristobal Street, Hofileña Subdivision, Silay City Negros Occidental, Philippines, 6116 


\section{APPENDIX L}

Map of the Philippines Indicating the Location of Sugar Mills and Refineries

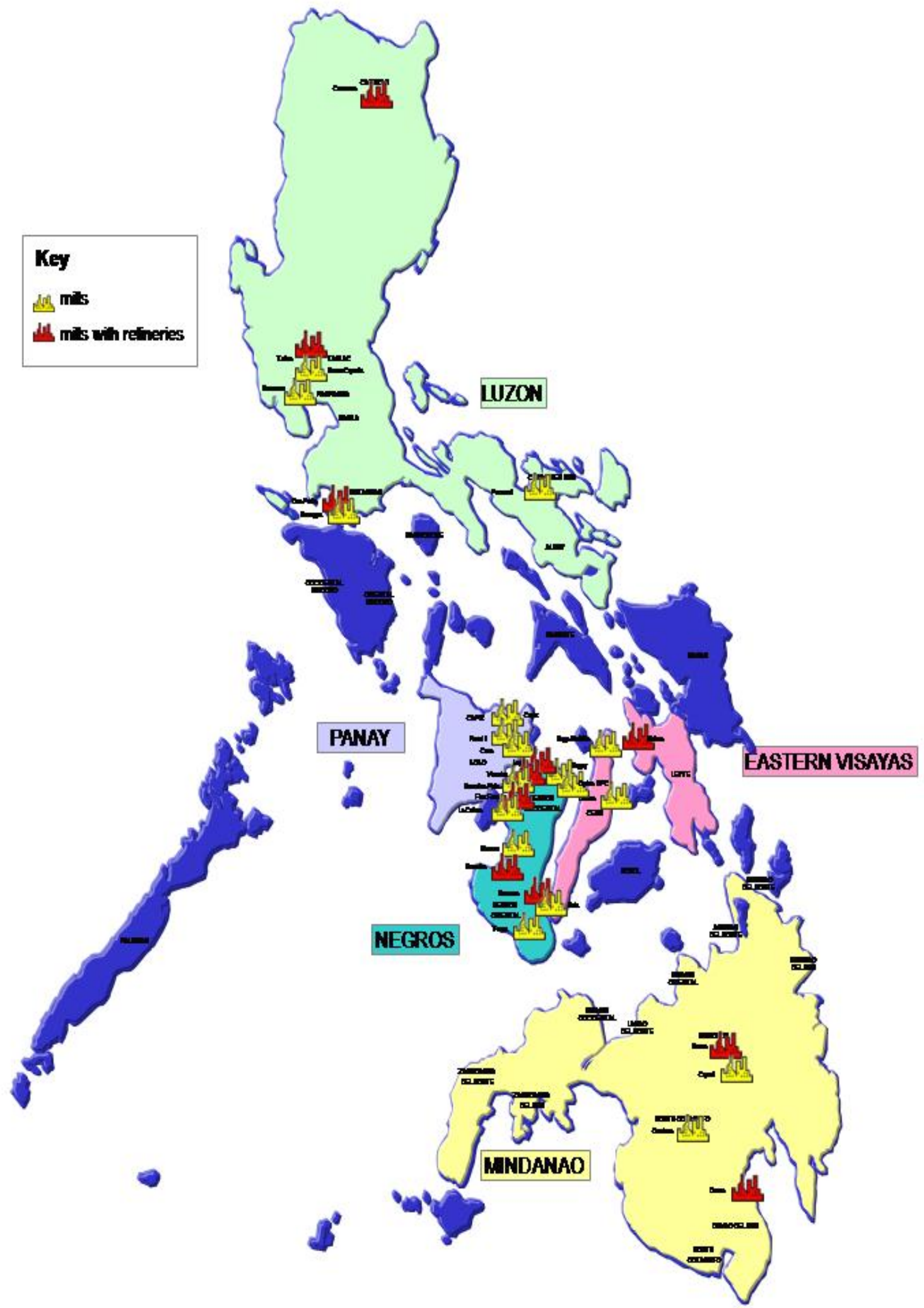




\section{APPENDIX M}

\section{Raw Sugar Production and Export to the United States}

\begin{tabular}{|c|c|c|c|}
\hline $\begin{array}{l}\text { Crop } \\
\text { Year }\end{array}$ & $\begin{array}{c}\text { Raw Sugar } \\
\text { Production } \\
\text { in metric tons }\end{array}$ & $\begin{array}{l}\text { Raw Sugar } \\
\text { Exports to U.S. } \\
\text { in metric tons } \\
\text { commercial weight }\end{array}$ & $\begin{array}{c}\text { Share of } \\
\text { U.S. Export to } \\
\text { Raw Sugar Production }\end{array}$ \\
\hline 1980-81 & $2,314,872.00$ & $1,541,213.00$ & $66.58 \%$ \\
\hline 1981-82 & $2,425,102.00$ & $1,105,618.00$ & $45.59 \%$ \\
\hline $1982-83$ & $2,465,162.00$ & $1,214,000.00$ & $49.25 \%$ \\
\hline 1983-84 & $2,335,622.00$ & $861,144.00$ & $36.87 \%$ \\
\hline 1984-85 & $1,722,209.00$ & $877,334.00$ & $50.94 \%$ \\
\hline $1985-86$ & $1,526,716.00$ & $278,114.00$ & $18.22 \%$ \\
\hline 1986-87 & $1,345,701.00$ & $156,492.00$ & $11.63 \%$ \\
\hline 1987-88 & $1,387,183.00$ & $146,289.00$ & $10.55 \%$ \\
\hline 1988-89 & $1,597,706.00$ & $180,746.00$ & $11.31 \%$ \\
\hline $1989-90$ & $1,753,420.00$ & $275,488.00$ & $15.71 \%$ \\
\hline 1990-91 & $1,719,630.00$ & $311,599.00$ & $18.12 \%$ \\
\hline 1991-92 & $2,010,844.73$ & $172,348.00$ & $8.57 \%$ \\
\hline $1992-93$ & $2,058,408.20$ & $264,960.00$ & $12.87 \%$ \\
\hline 1993-94 & $1,809,311.39$ & $271,538.00$ & $15.01 \%$ \\
\hline 1994-95 & $1,647,023.00$ & $149,529.00$ & $9.08 \%$ \\
\hline 1995-96 & $1,790,374.97$ & $229,112.00$ & $12.80 \%$ \\
\hline 1996-97 & 1,829,993.35 & $248,467.00$ & $13.58 \%$ \\
\hline 1997-98 & $1,802,744.00$ & $198,876.00$ & $11.03 \%$ \\
\hline 1998-99 & $1,624,322.00$ & $141,298.00$ & $8.70 \%$ \\
\hline 1999-00 & $1,619,613.00$ & $91,250.00$ & $5.63 \%$ \\
\hline 2000-01 & $1,805,203.00$ & $89,317.00$ & $4.95 \%$ \\
\hline 2001-02 & $1,898,501.00$ & $75,401.00$ & $3.97 \%$ \\
\hline 2002-03 & $2,161,525.00$ & $137,353.00$ & $6.35 \%$ \\
\hline 2003-04 & $2,338,574.00$ & $137,000.00$ & $5.86 \%$ \\
\hline 2004-05 & $2,150,746.00$ & $137,352.68$ & $6.39 \%$ \\
\hline 2005-06 & $2,138,075.00$ & $213,316.75$ & $9.98 \%$ \\
\hline 2006-07 & $2,233,453.00$ & $175,000.00$ & $7.84 \%$ \\
\hline 2007-08 & $2,455,027.00$ & $125,200.67$ & $5.10 \%$ \\
\hline 2008-09 & $2,100,148.00$ & $137,343.10$ & $6.54 \%$ \\
\hline 2009-10 & $1,970,784.00$ & $170,957.37$ & $8.67 \%$ \\
\hline
\end{tabular}




\section{APPENDIX N}

\section{A Picture of a Sugar Quedan}

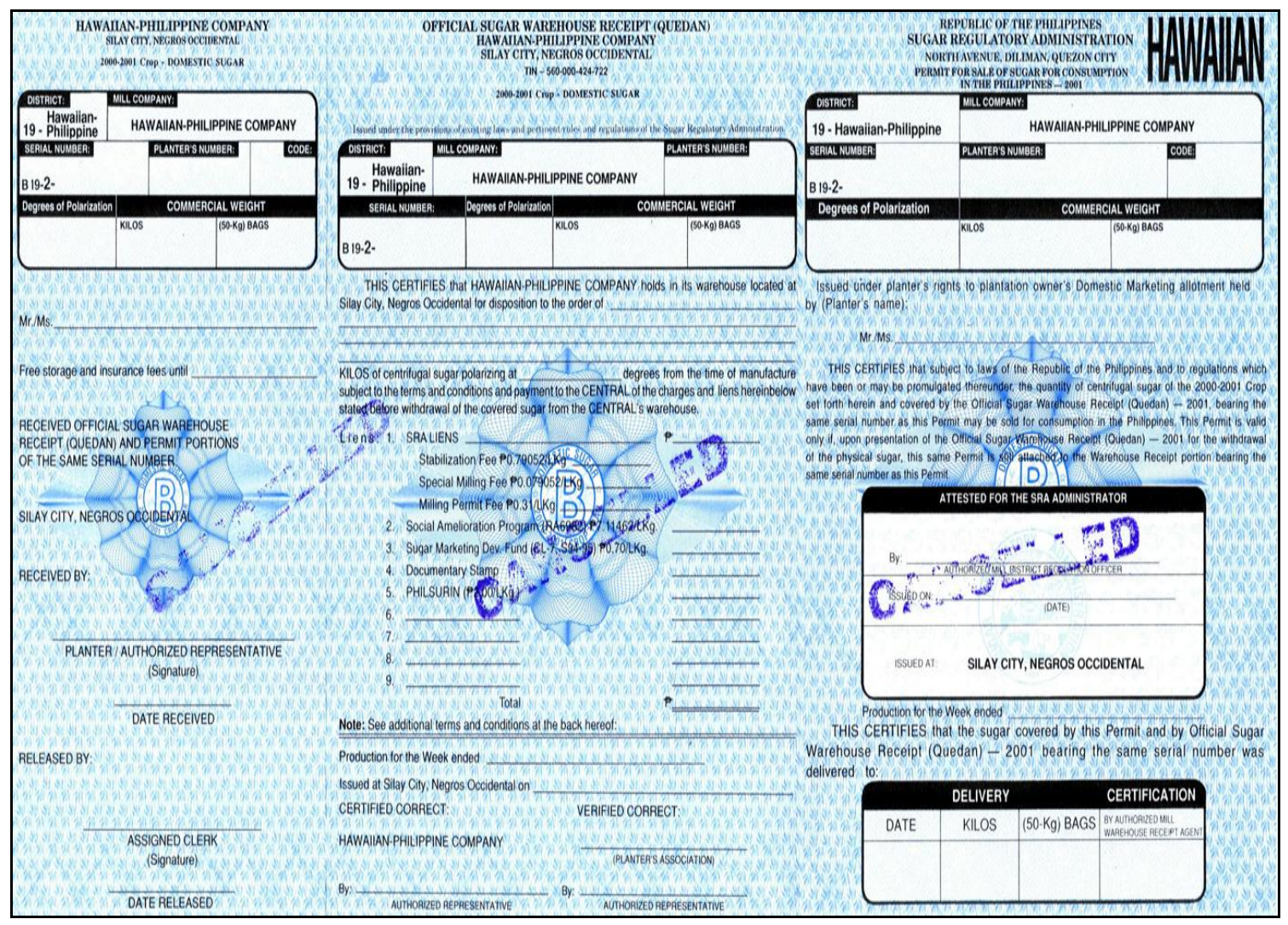

